\title{
FONTES DE CRESCIMENTO DAS PRINCIPAIS CULTURAS DO RIO GRANDE DO NORTE, 1981-92
}

\author{
CLÁUDIA GONDIM MOREIRA \\ Economista
}

Orientadora: Prof". Dra. ZILDA PAES DE BARROS MATTOS

Dissertação apresentada à Escola Superior de Agricultura "Luiz de Queiroz", Universidade de São Paulo, para obtenção do título de Mestre em Ciências, Área de Concentração: Economia Aplicada

PIRACICABA

Estado de São Paulo - Brasil

Outubro - 1996 
Dados Internacionais de Catạlogação na Publicação (CIP) DIVISÃo DE BIBLIOTECA E DOCUMENTAÇÃO - Campuśs "Lìiz de Queiroz"/USP

Moreira, Cláudia Gondim Fontes de crescimento das principais culturas do Rio grande do Norte, 1981-92 / Claúdia Gondim Moreira. - - Piracicaba, 1996.

108 p. : il.

Dissertaçāo (mestrado) - Escola Superior de Agricuittura Luiz de Queiroz, 1996.

Bibliografia.

1. Economia agricola - Rio Grande do Norte 2. Produção agricola - Crescimento - Rio Grande do Norte I. Titulo

CDD 338.109813 


\section{FONTES DE CRESCIMENTO DAS PRINCIPAIS \\ CULTURAS DO RIO GRANDE DO NORTE, 1981-92}

CLÁUDIA GONDIM MOREIRA

Aprovada em: 06/12/1996.

Comissão julgadora:

Prof. Dr. PAULO FERNANDO CIDADE DE ARAÚJO

ESALQ/USP

Prof ${ }^{\mathrm{A}}$. Dra. ZILDA PAES DE BARROS MATTOS

ESALQ/USP

Prof $^{a}$. Dra. MARIA APARECIDA ANSELMO TARSITANO UNESP-Ilha Solteira

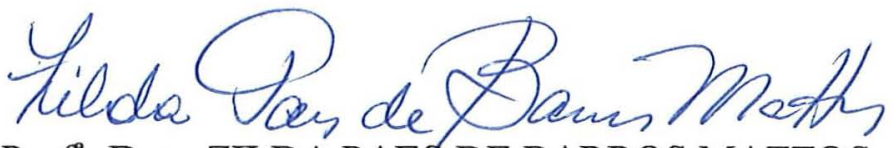

Prof $f^{\natural}$. Dra. ZILDA PAES DE BARROS MATTOS

Orientadora 
Aos meus queridos pais, LUIZ e NILZA.

Às minhas irmãs, Andrea, Patrícia e Érica.

À minha sobrinha, Jéssica.

Aos meus cunhados, Júlio e Erick.

DEDICO COM CARINHO. 


\section{AGRADECIMENTOS}

A Deus, pela fé e perseverança concedidos em todos os momentos da minha vida.

Aos meus pais, Luiz e Nilza, que não pouparam esforços para minha formação, seja de caráter ou profissional, a quem devo tudo e expresso minha eterna gratidão.

Às minhas irmãs Andrea, Patrícia e Érica, aos meus cunhados Júlio e Erick e à minha querida sobrinha Jéssica pelo carinho, amizade, força, confiança e incentivo para realização deste curso.

À Empresa de Pesquisa Agropecuária do Rio Grande do Norte S/A EMPARN e Empresa Brasileira de Pesquisa Agropecuária - EMBRAPA, pela oportunidade do treinamento.

A Escola Superior de Agricultura "Luiz de Queiroz" - ESALQ/USP, pela oportunidade para realização do curso.

Aos professores do Departamento de Economia e Sociologia Rural da ESALQ-USP, pelos conhecimentos e experiências transmitidas.

Aos funcionários do Departamento de Economia e Sociologia Rural da ESALQ-USP, pelo apoio dispensado.

À professora Zilda Paes de Barros Mattos pela amizade, orientação e atenção dedicada durante todo o transcorrer do desenvolvimento deste trabalho.

Aos professores Paulo Fernando Cidade de Araújo e Joaquim Bento de Souza Ferreira Filho pela criteriosa avaliação e pelas valiosas contribuições na realização desta pesquisa.

Aos membros da banca examinadora, Paulo Fernando Cidade de Araújo e Maria Aparecida Anselmo Tarsitano pelas críticas e sugestões oferecidas.

Aos meus grandes amigos, Maria da Piedade Araújo, Francisco Casimiro Filho e Sílvia H.G. de Miranda Stalder pelo companheirismo, estímulo e apoio durante 
nossa jornada, e, acima de tudo, pela amizade. Como também pelas críticas e sugestões apresentadas no desenvolvimento desta pesquisa.

Aos amigos do curso de Mestrado e Doutorado, Marina, Carliton, Alexandre Floriano, Robertinho, Patrízia, Jesús, Hillândia, Cristina, João, Ricardo Cota, Rodrigo, Thereza, Fabiano, Ricardo Martins, pela convivência, apoio e amizade.

A Lauriene Nakai Rodrigues, pela convivência amiga e pela cooperação em todos os momentos.

A Carlos Estevão Leite Cardoso, pesquisador da EMBRAPA/CNPMF, pela preciosa contribuição para o melhor entendimento da metodologia utilizada.

A todo corpo de pesquisadores e auxiliares da EMPARN, pela boa vontade e prontidão em atender às solicitações decorrentes do próprio andamento do trabalho, de modo especial a Luiz Gonzaga Lima Moreira, pesquisador da EMBRAPA, pelas sugestões e críticas apresentadas.

Ao Conselho Nacional de Pesquisa e Desenvolvimento Tecnológico CNPq, pela bolsa de estudo.

Enfim, a todos aqueles que tenham de alguma maneira contribuído para a realização do presente trabalho, seja através de uma saudação, lembrança, palavra e de um sorriso, meu "Muito Obrigada". 


\section{SUMÁRIO}

Página

LISTA DE FIGURAS …….......................................................................... vii

LISTA DE TABELAS......................................................................... viii

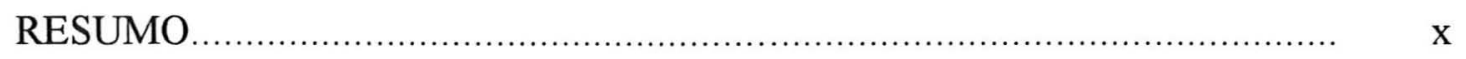

SUMMARY .............................................................................. xii

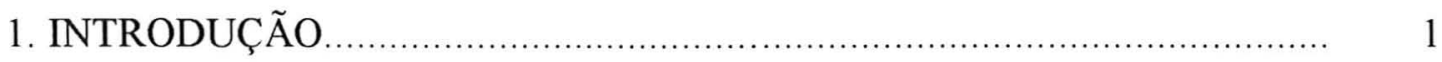

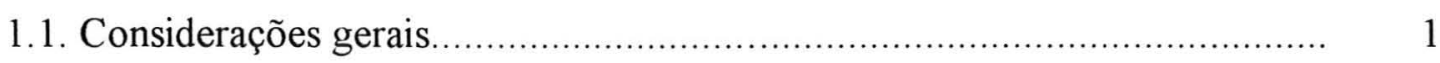

1.2. O problema e sua importância.............................................................. 6

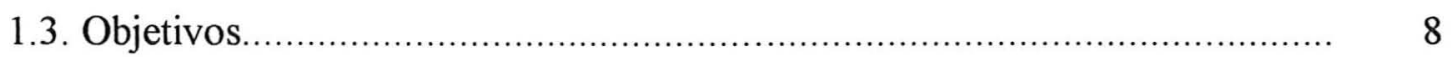

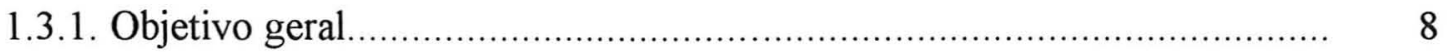

1.3.2. Objetivos específicos...................................................................... 8

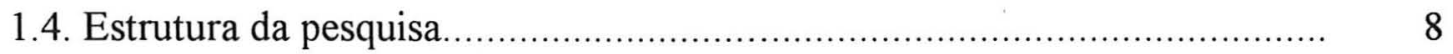

2. REVISÃO DE LITERATURA …….................................................... 10

3. MATERIAL E MÉTODO................................................................... 20

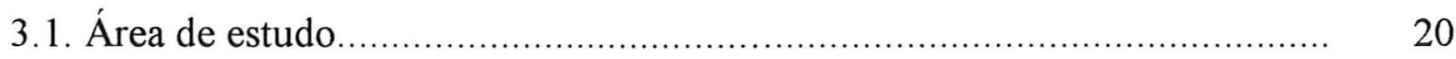

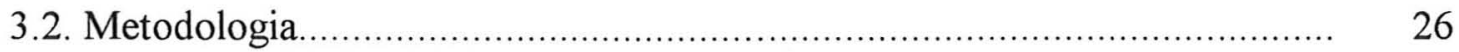

3.2.1. Descrição do Modelo "Shift-Share" ..................................................... 26

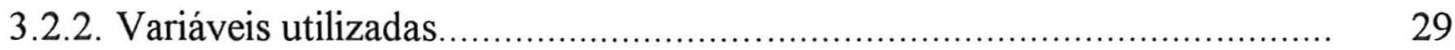

3.2.3. Decomposição da variação na produção............................................... 30

3.2.3.1. Análise por cultura no Estado........................................................ 30

3.2.3.1.1. Apresentação dos resultados: taxas anuais de crescimento............... 32

3.2.3.1.2. Decomposição do efeito área (efeitos escala e substituição)............... 33

3.2.3.2. Análise do conjunto de culturas em cada microrregião......................... 36

3.2.3.3. Análise do conjunto de culturas no Estado ......................................... 37

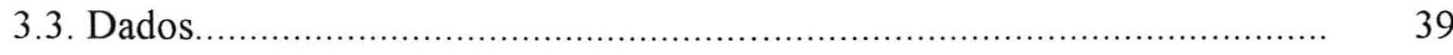


Página

4. RESULTADOS E DISCUSSÕES.................................................. 41

4.1. Expansão e substituição de culturas.............................................. 42

4.2. Análise por cultura no Estado...................................................... 48

4.3. Análise por microrregião para o conjunto das culturas....................... 74

4.4. Análise no Estado para o conjunto das culturas................................... 84

5. CONCLUSÃO

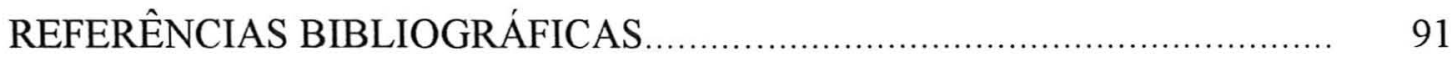

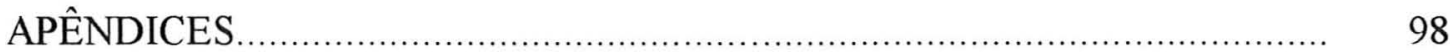

APÊNDICE 1

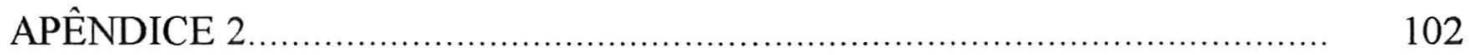

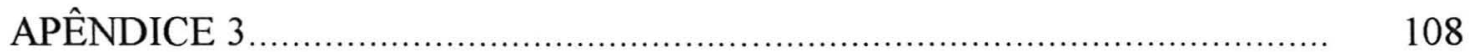




\section{LISTA DE FIGURAS}

Figura

Página

1 Microrregiões homogêneas do Estado do Rio Grande do Norte.

21

2 Tipos de clima do Estado do Rio Grande do Norte.................................. 22

3 Tipos de vegetação do Estado do Rio Grande do Norte .......................... 23

$4 \quad$ Bacias hidrográficas do Estado do Rio Grande do Norte........................ 24

$5 \quad$ Solos do Estado do Rio Grande do Norte ........................................... 25 


\section{LISTA DE TABELAS}

Tabela

Página

1 População urbana e rural do Rio Grande do Norte, 1970/1991 _............. 5

2 Participação percentual dos setores no PIB na região Nordeste............. 6

3 Participação percentual das microrregiões Salineira Norteriograndense, Litoral de São Bento do Norte, Açu-Apodi, Sertão Angicos e Serra Verde na área total cultivada de cada cultura do Estado do Rio Grande do Norte, 1981 e 1992.

4 Participação percentual das microrregiões de Natal, Serrana Norteriograndense, Seridó, Borborema Potiguar e Agreste Potiguar na área total cultivada de cada cultura do Estado do Rio Grande do Norte, 1981 e 1992

5 Decomposição do efeito área em efeitos escala e substituição, Rio Grande do Norte, no período de 1981 a 1992.

6 Decomposição do efeito área em efeitos escala e substituição, Rio Grande do Norte, no subperíodo de 1981 a 1985.

7 Decomposição do efeito área em efeitos escala e substituição, Rio Grande do Norte, no subperíodo de 1985 a 1989.

8 Decomposição do efeito área em efeitos escala e substituição, Rio Grande do Norte, no subperíodo de 1989 a 1992.

9 Taxa média anual de crescimento das culturas, decomposta em efeito área, rendimento e localização geográfica, Rio Grande do Norte, 1981-92

10 Taxa média anual de crescimento das culturas, decomposta em efeito área, rendimento e localização geográfica, Rio Grande do Norte, 1981-85 
11 Taxa média anual de crescimento das culturas, decomposta em efeito área, rendimento e localização geográfica, Rio Grande do Norte, $1985-89$

12 Taxa média anual de crescimento das culturas, decomposta em efeito área, rendimento e localização geográfica, Rio Grande do Norte, $1989-92$

13 Decomposição da taxa média regional e estadual, em efeitos explicativos do crescimento da produção das principais culturas, Rio Grande do Norte, 1981-92

14 Decomposição da taxa média regional e estadual, em efeitos explicativos do crescimento da produção das principais culturas, Rio Grande do Norte, 1981-85

15 Decomposição da taxa média regional e estadual, em efeitos explicativos do crescimento da produção das principais culturas, Rio Grande do Norte, 1985-89

16 Decomposição da taxa média regional e estadual, em efeitos explicativos do crescimento da produção das principais culturas, Rio Grande do Norte, 1989-92 


\title{
FONTES DE CRESCIMENTO DAS PRINCIPAIS \\ CULTURAS DO RIO GRANDE DO NORTE, 1981-92
}

\author{
Autora: CLÁUDIA GONDIM MOREIRA \\ Orientadora: Prof ${ }^{\sharp}$. Dra. ZILDA PAES DE BARROS MATTOS
}

\section{RESUMO}

O presente estudo tem como objetivo quantificar as fontes e diferenças regionais de crescimento do setor agrícola norte-riograndense, no periodo de 1981 a 1992, como também as possíveis mudanças na composição da produção vegetal, fornecendo, assim, indicadores que quantificam as fontes de mudanças na produção agrícola. Para medir essas fontes de crescimento utilizou-se o modelo "shift-share" e as alterações na composição da área cultivada do Estado, foram analisadas através da mensuração dos componentes do efeito área, que são os efeitos escala e substituição, na análise individual por cultura.

As culturas estudadas foram selecionadas através dos critérios de maior participação percentual em área cultivada e valor da produção, a saber: abacaxi, algodão arbóreo, algodão herbáceo, arroz, banana, batata-doce, caju, cana-de-açúcar, coco-dabaía, feijão, mandioca, manga, melão, milho, sisal e sorgo.

Constatou-se que a produção das culturas selecionadas do Rio Grande do Norte cresceu a uma taxa de 1,66\% ao ano, entre 1981 e 1992. Os efeitos composição da produção, rendimento e localização geográfica foram de maior importância em termos de explicação da variação na taxa de crescimento da produção agrícola estadual, ao contrário do efeito área que contribuiu negativamente. Portanto, o crescimento da produção agrícola no Rio Grande do Norte não ocorreu via incorporação de novas áreas. Ao contrário, houve sensível contração nas áreas cultivadas com as principais culturas incluidas nesta pesquisa. Isso significa que cerca de 228 mil hectares foram destinados a outros usos que não aqueles considerados no estudo (pastagens, reflorestamento, etc.). 
Os resultados mostraram também que as mudanças ocorridas na produção norte-riograndense na década de oitenta não seguiram um padrão convencional em termos de grupos de culturas. Três das maiores taxas anuais de crescimento da produção ocorreram em culturas tradicionais de subsistência: milho, feijão e arroz; três foram de culturas não tradicionais no Estado: melão, abacaxi e sorgo; finalmente, três foram de culturas tradicionais e em geral plantadas por grandes produtores: caju, coco-da-baía e cana-de-açúcar. Os principais efeitos explicativos do comportamento dessas culturas alternaram principalmente entre o efeito rendimento e o efeito área. O efeito localização geográfica foi positivo praticamente para todas as culturas. Percebe-se também que o subperíodo de maior crescimento foi entre 1981 e 1985, provavelmente influenciado pela regularidade climática do triênio 1984-85-86 e pela facilidade de obtenção do crédito subsidiado no início da década de 80.

Dentre as culturas que apresentaram declínio na produção, três foram industriais e/ou de exportação: algodão arbóreo, sisal e o algodão herbáceo; duas culturas de subsistência: batata-doce e mandioca; e por último, a banana, uma cultura recente e de alto valor comercial. A retração da área foi a principal fonte explicativa dessas taxas de crescimento negativa da produção.

Os resultados acima sugerem que os incentivos às culturas irrigadas, à recuperação de culturas como o caju e o coco-da-baía e à melhoria no material genético das culturas de subsistência, adotadas pelo governo estadual, surtiram efeito, ou seja, contribuíram positivamente para a mudança da composição da produção estadual.

As microrregiões que apresentaram taxas médias anuais positivas de crescimento da produção foram: Litoral de São Bento do Norte, Serra Verde, Salineira Norte-riograndense, Borborema Potiguar, Sertão de Angicos, Açu-Apodi e a Serrana Norte-riograndense. Os principais indicadores de crescimento nessas microrregiões foram as mudanças na composição da produção e o aumento do rendimento. Em todas as microrregiões percebe-se uma variação dos efeitos explicativos conforme os subperíodos analisados. As regiões do Seridó e do Agreste Potiguar foram as que tiveram maior retração na produção agrícola, devido à queda na área plantada. A microrregião de Natal teve um comportamento estável. 


\title{
SOURCES OF GROWTH OF THE MOST IMPORTANT CROPS \\ IN STATE OF RIO GRANDE DO NORTE, 1981-1992
}

\author{
Author: CLÁUDIA GONDIM MOREIRA \\ Adviser: Prof ${ }^{a}$. Dra. ZILDA PAES DE BARROS MATTOS
}

\section{SUMMARY}

The objective of the present study was to quantify the regional growth sources and differences of the "norte-riograndense" agricultural sector in the period 1981 to 1992 , as well as the changes occurred in crop combination. In order to measure those growth sources, the shift-share model was used and changes in the combination of cultivated crops' areas in the State were analysed through measurement of the areaeffect components which are the scale and substitution effects in the individual crop analyses.

The studied crops were selected by two criteria: crop area percentage in total state cultivated area and crop value percentage in total state agricultural production value. They were: pineapple, annual and perennial cotton, rice, banana, sweet potato, cashew, sugar cane, coconut ("coco-da-baia"), edible beans, manioc, mango, cantaloupe, corn, "sisal" and sorghum.

The results showed that production of the selected crops increased at 1,66\% per year, between 1981 and 1992. The crop combination, yield and geographical location were the most important explanatory effects as opposed to the area effect whose contribution to that growth rate was negative. Therefore, the increase in the state agricultural production was not due to increased cultivated area. On the contrary, there was a significant reduction in total cultivated area of selected crops. Approximately 228 thousand hectares were allocated to other activities not considered by this research.

The results also showed that changes in agricultural production in the state did not follow a pattern with respect to crops' groups. Three of the highest production growth rates belonged to traditional subsistence crops: corn, edible beans and rice; 
immediately below those rates were three non traditional crops: cantaloupe, pineapple and sorghum; finally, three of the crops with positive growth rates, were traditional crops usually cultivated by large farmers: cashew, coconut and sugar cane. The main explanatory effects of these crops' growth rates alternated between yield and area effects. The geographical location effect was positive for most of the crops. It could be observed that the highest growth rates occurred between 1981 and 1985, probably because of the good climate conditions in the years 1984-85-86 and also due to the availability of subsidized rural credit in the first half of the 80 's.

Among the crops with declining production, in the period, three were export and/or industrial crops: annual and perennial cotton and "sisal"; two subsistence crops: sweet potato and manioc; finally, a new state crop with high commercial value: banana. Area reduction was the most important explanatory effect for these negative agricultural production growth rates.

The above results suggest that the incentives given to the irrrigated crops as well as the recovery of crops such as cashew and coconut and the genetic material improvement of the subsistence crops, adopted by the state government, have taken effect. In other words, they have positively contributed to the changes in the state crop combination in the analysed period.

The following "microrregião"1 presented positive annual average growth rates: Litoral de São Bento do Norte, Serra Verde, Salineira Norte-riograndense, Borborema Potiguar, Sertão de Angicos, Açu-Apodi and Serrana Norte-riograndense. The main growth indicators in these regions were changes in crop combinations and yield increase. Explanatory effects varied among "microrregião" in the different subperiods. The regions of Serido and Agreste Potiguar were the ones whose production decreased the most due to reduction in the crops' cultivated area. The results showed that production in the Natal "microrregião" was stable during the period.

\footnotetext{
"Microrregião" is a state division characterized by counties with similar climate, soil, social and economic conditions adopted by the Brazilian Institute of Geography and Statisitcs (FIBGE).
} 


\section{INTRODUÇÃO}

\subsection{Considerações gerais}

Este estudo tem como objetivo identificar as fontes de crescimento das principais culturas do setor agrícola norte-riograndense, no período de 1981 a 1992. Espera-se que os resultados sirvam de subsídio às políticas governamentais voltadas para o setor.

A importância da agricultura no desenvolvimento econômico de um país é largamente reconhecida na literatura. Segundo Johnston \& Mellor (1961) e Schuh (1975), a agricultura tem um papel importante no processo de desenvolvimento econômico de um país, através da transferência dos recursos produtivos capital e mão-deobra para expansão dos outros setores; dos ganhos cambiais que facilitam a obtenção de recursos que são necessários durante o processo de desenvolvimento; do fornecimento de alimentos para a população e matérias-primas para o setor industrial.

Para Hayami \& Ruttan (1975), a promoção do desenvolvimento agrícola depende da habilidade de eleger e pôr em prática as inovações tecnológicas que facilitem a substituição de fatores de produção relativamente escassos e, portanto, mais caros, por outros relativamente abundantes. Assim, as inovações mecânicas levariam mais facilmente um país, ou mesmo uma região, à elevação da produtividade do trabalho, quando a mão-de-obra é escassa. Ao contrário, onde há escassez de terra, inovações biológico-químicas constituem elemento-chave para aumentar a produtividade da terra. Segundo esses autores, a diferença de produtividade entre regiões e países depende: da quantidade e qualidade dos recursos naturais disponíveis; da tecnologia incorporada ao capital fixo e trabalho, e do capital humano, incluindo-se educação, habilidade, grau de conhecimento, ou seja, da capacidade da população como um todo. Além disso, consideram que a capacidade industrial para produzir insumos modernos tem que ser desenvolvida. As inovações tecnológicas poupadoras de terra no Japão e de mão-de- 
obra nos Estados Unidos, recursos escassos nesses paises, ilustram bem o modelo de Hayami e Ruttan.

O processo de modernização da agricultura brasileira, por outro lado, se dá em condições de mercado bastante diferentes daquelas prevalecentes nos Estados Unidos e no Japão. A política de crédito rural subsidiado, aliada às políticas de industrialização e de taxas de câmbio, e a legislação do trabalhador rural, por exemplo, alteraram os preços do capital e do trabalho, tornando o primeiro relativamente mais barato. A adoção dessas políticas provocou várias mudanças no setor agrícola brasileiro, como: substituição de tecnologias de produção de mão-de-obra intensivas por tecnologias capital intensivas, tendência crescente do uso de mão-de-obra temporária em detrimento da mão-de-obra permanente e aumento da desigualdade da distribuição de renda.

Para Kageyama \& Silva (1983), o processo de modernização da agricultura nos anos 70 consistiu na reafirmação das características capitalistas do setor, à medida que provocou uma grande concentração da renda pessoal. No período entre 1970 e 1980 ocorreu uma redução da desigualdade de renda entre os setores rural e urbano, acompanhada de um aumento da desigualdade dentro do setor agrícola. Segundo Hoffmann \& Kageyama (1985), os Estados com maior grau de modernização têm maior renda média, apresentando menor grau de pobreza.

A economia brasileira passou por três ciclos nos últimos anos: o auge do ciclo expansivo (1970-1973), a fase de desaceleração (1974-1980) e a crise e estagnação dos anos 80 (1980-1990). Foi dentro desse contexto econômico que ocorreram as transformações da agricultura brasileira. Os movimentos da economia nordestina, particularmente da norte-riograndense, tendem a seguir a economia brasileira, às vezes com alguma defasagem, e quase sempre com intensidade menor.

Observa-se, entretanto, uma profunda heterogeneidade no processo de modernização, onde regiões como Centro-Sul têm alcançado notáveis incrementos na produção e na produtividade, enquanto outras permanecem utilizando processos de produção tradicionais, como algumas regiões do Nordeste. Além das diferenças estruturais entre as regiões, a desigualdade na distribuição do crédito acabou 
aprofundando ainda mais as diferenças no grau de modernização agrícola e no processo de distribuição de renda do País.

Além da introdução de novos insumos e/ou técnicas de produção, Patrick (1975) considera outras fontes de variação da produção agrícola, como: o aumento do uso de recursos tradicionais, a alocação mais eficiente dos fatores de produção, as economias externas, além das mudanças provocadas por fenômenos naturais. Essas fontes de crescimento variam conforme o país, os produtos e as regiões de um país e produtos de uma mesma região. Segundo o autor, a análise dessas fontes e mudanças no tempo servem como indicadores do estágio de desenvolvimento, isto é, permite um melhor entendimento do processo de desenvolvimento agrícola.

Desde 1959, a principal via de atuação do Governo Federal sobre a economia dos estados nordestinos para o desenvolvimento da região, foi a Superintendência do Desenvolvimento do Nordeste (SUDENE). Esse órgão coordena programas especiais para o desenvolvimento industrial e rural da economia nordestina. O Programa de Desenvolvimento de Áreas Integradas do Nordeste (POLONORDESTE) tem como objetivo o desenvolvimento e a modernização da economia tradicional do Nordeste, em apoio aos pequenos produtores rurais localizados em áreas prioritárias, facilitando o seu acesso ao crédito e a introdução de tecnologias modernas nos processos de produção agropecuária. Atualmente esse programa denomina-se Programa de Apoio aos Pequenos Produtores (PAPP). O Projeto Sertanejo interfere na região semi-árida do Nordeste a fim de tornar sua agricultura mais resistente à seca. Esse projeto enfatiza a organização e reorganização das unidades produtivas da região, de modo a estabilizar o processo de produção e assegurar o nível de emprego, reduzindo as repercussões de natureza social provocadas pelo fenômeno das secas. O Programa de Irrigação tem por finalidade empreender ações capazes de dinamizar a infra-estrutura hídrica regional, permitindo assim, o aproveitamento e utilização da infra-estrutura hidrográfica, proporcionando um aumento da oferta de matéria-prima, de alimentos e de emprego. $\mathrm{O}$ Programa de Desenvolvimento da Agroindústria do Nordeste (PROINE) tem grande importância na integração da agricultura ao complexo agroindustrial dentro do processo 
de modernização, principalmente nos ramos de processamento e beneficiamento de matérias-primas provenientes desse setor (Romão et al., 1990).

Apesar de todos esses programas, o Nordeste é a região mais pobre do Brasil, sua população rural apresenta elevados índices $(55,8 \%$ em 1990) de analfabetismo (Veras et al., 1993), dificultando ainda mais a introdução de novas tecnologias de produção. De qualquer maneira, esses baixos índices sociais não indicam que a SUDENE falhou com seus objetivos na região, pois o papel desse órgão era "interromper o processo de agravamento das diferenças regionais, não de eliminá-las" (Pereira 1982, p.85). Entretanto, na opinião do autor, esse órgão poderia ter liquidado o capital mercantil da agricultura nordestina como também servido de instrumento de reforma agrária, o que não foi feito.

Segundo Veras et al. (1993), o Nordeste abriga 29\% da população brasileira e participa com 13\% no Produto Interno Bruto. A partir de 1970, a participação da agropecuária na formação do PIB nordestino passou a diminuir, como também a absorção de mão-de-obra. Isso contribuiu para uma crescente urbanização da população rural, agravada periódica e sistematicamente pelos fenômenos de secas e enchentes. Para Romão et al. (1990), três fenômenos explicam essa migração ruralurbana, além dos fatores estruturais (estrutura fundiária) e climáticos: a substituição do trabalho familiar nas pequenas propriedades da Zona da Mata nordestina com a intensificação das culturas comerciais, como cana-de-açúcar; a mudança de ocupação das lavouras pela pecuária no Agreste semi-árido e a modernização da agroindústria. Todas essas mudanças tiveram como conseqüência a diminuição da demanda por trabalho, forçando assim o homem do campo a migrar para a zona urbana.

Como se pode observar na Tabela 1, esse processo de urbanização também ocorreu no Estado do Rio Grande do Norte, agravando ainda mais os problemas de desemprego, subemprego e pobreza urbanos. A taxa de crescimento médio anual da população norte-riograndense no período de 1980-91 foi de 2,22\% (superior à brasileira, $1,93 \%$ ), sendo na área urbana de $3,74 \%$ e na área rural de $-0,44 \%$. Já a população urbana brasileira cresceu à taxa de 2,97\% e a rural à taxa de -0,67\% (IBGE 1994). Esse esvaziamento do campo é preocupante, pois tende a aumentar o contigente de pobres no 
Estado, como foi verificado por Cortez et al. (1994). Em 1980, a percentagem de chefes de domicilios na faixa de até $1 / 2$ salário mínimo, que era de $23,12 \%$, passou para $39,73 \%$ em 1991. Analisando pela concentração por cortes percentis, constataram que os $10 \%$ mais ricos que detinham 50,4\% em 1980, passaram a deter 54,6\% da renda em 1991 , enquanto os $10 \%$ mais pobres tiveram um decréscimo na participação da renda no mesmo período de $1,2 \%$ para $0,6 \%$.

Tabela 1 - População urbana e rural do Rio Grande do Norte, 1970/1991

\begin{tabular}{cccc}
\hline \multirow{2}{*}{ ANO } & \multicolumn{3}{c}{ POPULAÇÃO } \\
\cline { 2 - 4 } & URBANA & RURAL & TOTAL \\
\hline 1970 & 599.553 & 950.691 & 1.550 .244 \\
& $(38,7)^{\mathrm{a}}$ & $(61,3)$ & $(100,0)$ \\
1980 & 1.022 .792 & 875.380 & 1.898 .172 \\
& $(53,9)$ & $(46,1)$ & $(100,0)$ \\
1991 & 1.668 .165 & 745.956 & 2.414 .121 \\
& $(69,1)$ & $(30,9)$ & $(100,0)$ \\
\hline
\end{tabular}

Fonte: Censos Demográficos do FIBGE

${ }^{a}$ os números entre parênteses indicam participação percentual em relação à população total.

Almeida \& Soares (1994) afirmam que mesmo com a queda da participação do setor primário no PIB (Tabela 2), a região Nordeste apresentou ganhos de qualidade na natureza do sistema produtivo, principalmente nos rearranjos das composições dos produtos, favorecendo principalmente as culturas industriais (algodão, cana-de-açúcar, mamona e coco-da-baía) em detrimento das culturas de subsistência (milho, feijão, arroz, mandioca e batata-doce), refletido na migração rural-urbana descrita acima. No período de 1970-87, o Rio Grande do Norte foi o terceiro estado nordestino em termos de crescimento do PIB, com uma taxa média anual em torno de $8,5 \%$, contribuindo nesse período para explicar $5,7 \%$ do crescimento do PIB nordestino (Gomes, 1993). 
Tabela 2 - Participação percentual dos setores no PIB na região Nordeste

\begin{tabular}{cccc}
\hline Anos & \multicolumn{3}{c}{ Setores } \\
\cline { 2 - 4 } & Primário & Secundário & Terciário \\
\hline 1965 & 29,0 & 23,1 & 47,8 \\
1970 & 21,0 & 27,4 & 51,6 \\
1975 & 23,9 & 27,6 & 48,5 \\
1980 & 17,3 & 29,3 & 53,4 \\
1985 & 16,2 & 30,2 & 53,6 \\
1990 & 15,1 & 27,0 & 57,9 \\
\hline
\end{tabular}

Fonte: Almeida \& Soares (1994)

\subsection{0 problema e sua importância}

Como em todo o Brasil, o processo de modernização da agricultura nordestina ocorreu de maneira bastante heterogênea, existindo as lavouras capitalintensivas (utilizando máquinas e implementos agrícolas, adubos, irrigação, manejo de solo e pesticidas) representadas principalmente pelas culturas industriais e de exportação e aquelas que utilizam técnicas pouco sofisticadas, dispondo apenas da força de trabalho familiar, no cultivo de culturas de subsistência. O Estado do Rio Grande do Norte faz parte desse panorama, além de possuir uma estrutura fundiária extremamente concentrada, ou seja, dos 116 mil estabelecimentos que ocupam uma área de 4.408 milhões de hectares, cerca de $65,4 \%$ dos estabelecimentos têm menos de 10 hectares, ocupando apenas $4,74 \%$ do total da área cadastrada (FIDEC, 1990). Na maioria desses estabelecimentos os agricultores são analfabetos, cultivam terras de pior qualidade com técnicas rudimentares, dificultando a adoção das novas tecnologias que os beneficiariam no aumento da produtividade da terra e do trabalho.

Assim como grande parte dos estados nordestinos, o Rio Grande do Norte possui sua configuração espacial centrada em três tipos de região: a região da Mata, porção imune ao fenômeno das secas; Agreste, região intermediária entre a faixa úmida e 
o interior semi-árido; e o Sertão, região semi-árida que cobre a maior parte do território estadual.

Apesar do declínio da população rural norte-riograndense e do setor primário responder por apenas $6 \%$ do PIB estadual em 1990, esse setor continua a ser um grande absorvedor da força de trabalho disponível, haja vista que em 1990 empregava $31,1 \%$ da população economicamente ativa (FIDEC, 1994). A agricultura absorve, portanto, uma proporção relevante da mão-de-obra, mostrando-se fundamental para o desenvolvimento da economia norte-riograndense. Devido a este fato e também pelos diversos programas e as políticas adotadas nos últimos anos, que tiveram por intuito fortalecer e auxiliar no desenvolvimento do Nordeste, se faz necessário uma avaliação das possíveis transformações ocorridas no setor agrícola do Estado. O conhecimento dos efeitos dessas políticas e desses programas na produção norte-riograndense poderá constituir importante subsídio às futuras ações governamentais, pois, como foi visto, é através do incremento da produção e/ou da produtividade que uma região crescerá, podendo assim promover alterações significativas no seu quadro social.

Sabe-se que, além da instabilidade climática que lhe é inerente, a agricultura é marcada pelas oscilações de políticas tais como as de crédito agrícola, de preços mínimos, cambial e de comércio exterior, da geração e difusão de tecnologia e da industrialização, as quais interferem direta e indiretamente nos negócios agrícolas, provocando transformações na composição da produção do Estado, no padrão tecnológico e no mercado dos fatores. E como cada região ou Estado responde de maneira diferenciada a esses estímulos, segundo as suas características específicas, pretende-se analisar como essas transformações ocorreram no Rio Grande do Norte, através da análise das fontes de crescimento, que neste trabalho correspondem a variações: na área cultivada, na produtividade, na localização geográfica entre regiões e na composição do produto devido a mudanças nos padrões de culturas.

A obtenção desses indicadores de desempenho agrícola, que refletem mudanças nas fontes e diferenças regionais de crescimento do setor de culturas, permitirá um melhor conhecimento do setor agrícola de cada microrregião, auxiliando a formulação 
de futuras políticas agrícolas regionais e as de geração e difusão de tecnologia, em particular.

\subsection{Objetivos}

\subsubsection{Objetivo Geral}

Para analisar as transformações ocorridas na agricultura norteriograndense, no período de 1981 a 1992, o presente estudo tem como objetivo principal quantificar as fontes e diferenças regionais de crescimento do setor agrícola, como também as possíveis mudanças na composição da produção vegetal, fornecendo assim indicadores que quantificam as fontes de mudanças na produção agrícola.

\subsubsection{Objetivos Específicos}

a) calcular e decompor as taxas médias anuais de variações na produção nos efeitos área, rendimento, localização geográfica e composição da produção, para o Estado e por microrregião;

b) decompor o efeito área nos efeitos escala e substituição para determinar as expansões e retrações das áreas das culturas, analisando assim as alterações ocorridas nos padrões de cultivo (o deslocamento das culturas) no Estado do Rio Grande do Norte;

c) discutir os resultados alcançados com base nos fatores que afetam a produção, como as políticas e programas agrícolas estaduais e os fatores climáticos.

\subsection{Estrutura da pesquisa}

Além desse capítulo introdutório, este trabalho consta de mais quatro. No segundo capítulo é feita uma retrospectiva das principais políticas agrícolas e econômicas que afetaram de alguma maneira o desempenho do setor agrícola brasileiro. Também são citados alguns autores que, ao analisar a evolução agrícola nacional ou regional, explicam a variação da produção através dos efeitos área, produtividade, localização geográfica e composição das atividades. No Capítulo 3 é feita uma breve descrição e caracterização da área de estudo e de como foram obtidos os dados da área colhida e da produção estadual e das microrregiões. Também é feita neste capítulo uma descrição da 
metodologia utilizada na decomposição das taxas médias anuais de crescimento da variação da produção agrícola em efeitos área, rendimento, localização geográfica e composição da produção, através da utilização do modelo "shift-share". No quarto capítulo são discutidos os resultados. E para finalizar o estudo, no Capítulo 5, são apresentadas as principais conclusões da pesquisa. 


\section{REVISÃO DE LITERATURA}

Neste capítulo são analisados de maneira sucinta os fatores que influenciam na variação da produção, mais especificamente do Nordeste. Também procura-se apresentar uma descrição das políticas adotadas nas duas últimas décadas, relacionando-as sempre que possível com o desempenho do setor. E, para finalizar, são apresentadas algumas evidências empíricas das fontes regionais de crescimento do setor agrícola brasileiro.

A agricultura brasileira passou por grandes transformações nas duas últimas décadas. Foram vários os programas e políticas, tanto econômicas como agrícolas, que influenciaram o desempenho do setor no País. Particularmente na economia nordestina essa análise adquire grande importância, dada a elevada participação do setor agrícola na absorção da força de trabalho disponível.

Várias são as hipóteses sobre os fatores que condicionam o aumento da produção agrícola, seja através do crescimento da produtividade e/ou expansão da área. Para Olivetti \& Camargo (1992), isso depende em grande parte de um eficiente sistema de pesquisa e extensão rural. Já para Alves \& Contini (1992), o uso de tecnologia moderna e os investimentos na indústria correspondente são um sinal de opção pelo aumento da produtividade da terra e do trabalho. O Brasil optou por isso na década de sessenta, quando passou a investir maciçamente na implantação do parque industrial voltado para agricultura (agroindústrias). Isso provocou uma mudança na base técnica do setor, principalmente do Centro-Sul, onde atualmente se situa grande parte da indústria brasileira.

Entretanto, devido à própria evolução da sua história e o modo como foi inserido no processo de acumulação de capital do País, o Nordeste teve um processo de industrialização tardio. E o nível de renda em uma região que experimenta forte crescimento industrial aumenta em comparação com aquelas que não experimentam tal 
crescimento, como é o caso do Nordeste. Isso é confirmado por Schultz citado por Schuh (1975), ao afirmar que quanto mais perto uma região está de um centro urbanoindustrial, mais alto será o seu nível de renda.

Além disso, a estrutura fundiária extremamente concentrada, o dificil acesso ao crédito rural subsidiado, aliados aos baixos níveis cultural e educacional na maioria dos agricultores, são apontados por diversos autores como importantes fatores impeditivos da modernização mais abrangente da agricultura nordestina (Furtado, 1973; Carneiro, 1982; Leite, 1983; Hoffmann et al., 1985; Alves, 1988; Silva et al., 1989; Cortez et al., 1994).

Para Aguiar (1985), fatores como o crescimento demográfico, a forma como as classes sociais barganham e dividem o poder, os vícios institucionais que caracterizam os atuais sistemas de posse e uso da terra e a baixa capacidade de absorção da força de trabalho pelos setores secundário e terciário no Nordeste fazem com que apenas as minorias privilegiadas participem do processo de modernização.

Para que se possa melhor compreender as transformações do setor agrícola no Nordeste, especificamente no Rio Grande do Norte, é necessário fazer uma retrospectiva das políticas agrícolas e econômicas adotadas no Brasil nas décadas de 70 e 80 , de forma a visualizar o cenário em que ocorreram essas mudanças no sistema produtivo. Observa-se que o Estado teve um papel fundamental na geração e no financiamento desse processo.

Antes dos anos 70, o crescimento da agricultura se deu principalmente pela incorporação de novas áreas e pelo emprego de mão-de-obra. Na década de 70 , a política agrícola brasileira tinha como alvo o aumento da produtividade da terra e do trabalho através da modernização do setor. Difundiram-se por todo o território nacional incentivos à pesquisa e à extensão rural, liderados pela Empresa Brasileira de Pesquisa Agropecuária (EMBRAPA) e pela Empresa Brasileira de Extensão Rural (EMBRATER). Entretanto, foi o crédito rural subsidiado que realmente intensificou esse processo, dado seu objetivo de assegurar um crescimento estável da produção agropecuária nacional, baseado no uso mais intensivo de insumos modernos, estimulando, ao mesmo tempo, o desenvolvimento do parque agroindustrial brasileiro, consoante as metas do programa 
mais amplo de industrialização por meio da substituição de importações (Barros \& Araújo, 1991). Paralelamente, ampliaram-se as redes de estradas, comunicações, armazéns e silos. Todas essas políticas beneficiaram o aumento da produtividade na agricultura.

Além da abundância e baixo custo do crédito rural, a década de 70 foi marcada por uma relativa estabilidade da taxa de câmbio, uma evolução satisfatória dos preços recebidos pelos produtores e oscilações nos preços pagos de combustíveis e fertilizantes (Mesquita, 1994). A política de preços mínimos, também adotada no período, foi orientada principalmente para a solução de problemas de curto prazo, sendo um instrumento de alteração da composição e do nivel de oferta agrícola que privilegiou as culturas destinadas à exportação (Olivetti \& Camargo, 1992).

Em suma, a economia brasileira chegou ao ápice do ciclo expansivo no período de 1968-73, ficando o mesmo conhecido como período do "milagre econômico" devido às elevadas taxas de crescimento da economia. A partir de 1973, o País iniciou um período de desaceleração do crescimento provocado pela elevação do preço do petróleo. No decorrer dessa crise, com tendência à queda persistente das relações de trocas internacionais, os recursos privados e governamentais foram canalizados para investimentos no programa de substituição de importações de bens de capital e insumos básicos. Ainda, o segundo choque do petróleo, em 1979, o aumento das taxas internacionais de juros e outros fatores levaram a uma situação crítica do Balanço de Pagamentos e da taxa de inflação. Tudo isso provocou uma desorganização do processo produtivo com efeitos depressivos sobre todos os setores da economia, inclusive o agrícola.

Apesar do crescimento da economia brasileira nas décadas de 60 e 70 , as políticas econômicas adotadas, tais como: taxa cambial relativamente sobrevalorizada, política comercial que criava barreiras de proteção à indústria nacional, política de abastecimento que procurava conter o custo de vida e a institucionalização de um sistema de crédito subsidiado também contribuíram para o "agravamento dos problemas estruturais do País, como a concentração da renda nacional em termos pessoais, funcionais e regionais (Barros \& Araújo, 1991, p. 3)”. 
Na primeira metade da década de 80 , a recessão estabeleceu-se no País, que apresentou taxas inéditas de crescimento econômico negativo. Foram implementadas várias políticas econômicas bastante instáveis, devido aos instrumentos utilizados que variaram do ortodoxo para o heterodoxo, dirigidos para todos os setores da economia. Segundo Barros \& Álvaro (1992), essas variações nos instrumentos da política econômica acabaram provocando componentes de instabilidade na comercialização agrícola, nos investimentos rurais, na produção industrial de insumos modernos e nos preços das terras agricultáveis. A evolução desfavorável dos preços mínimos, a partir de 1986 e a redução nos níveis de subsídios ao crédito rural, diminuindo a demanda pelos insumos modernos, geraram um período de crise no setor agrícola, agravada por fatores climáticos.

Portanto, a década de 80 caracterizou-se por dificuldades provocadas tanto por fatores externos como: o segundo choque do petróleo, a recessão mundial e a queda dos preços dos produtos agrícolas no mercado externo, como internos: os problemas climáticos, aumento da dívida pública, aceleração inflacionária, crise cambial e redução da oferta do crédito agrícola acompanhada da redução gradual do subsídio. Apesar disso, a agricultura apresentou nesses anos de crise e estagnação, um desempenho médio bastante superior ao da indústria, com sucessivos recordes de safras em 1987, 1988 e 1989 (Nakano, 1992). Esse desempenho na década de 80, contrasta com o da década de 70, quando a indústria cresceu a uma taxa duas vezes maior do que a agricultura. Para o autor, dois fatores podem explicar esse bom desempenho: o crédito abundante e subsidiado até meados da década de 80 que permitiu uma capitalização da agricultura, a incorporação definitiva de novas áreas como o Centro-Oeste e uma mudança na estrutura produtiva com a modernização tecnológica; e o segundo fator só veio com a mudança na política de preços mínimos em meados da década de 80 , quando o crédito subsidiado foi substituído por uma garantia de melhor preço para o agricultor, o que trouxe um aumento na receita do setor agrícola, pelo menos até 1986.

Muitas dessas políticas, no entanto, implicaram a discriminação contra o pequeno produtor, pois as inovações tecnológicas que realmente ocorreram tiveram lugar entre os grandes produtores, em produtos de exportação e em certas regiões. Silva 
(1982) argumenta que o Brasil adotou um modelo de modernização conservador, privilegiando alguns produtos e regiões, médios e grandes produtores, fazendo o País transformar o processo produtivo e alcançar expressivos niveis de crescimento do produto, mas mantendo elevados níveis de pobreza absoluta e uma distribuição de renda muito concentrada. Para verificar isso, Pereira (1993) analisou as diferenças no grau de modernização tecnológica da agricultura entre as regiões Nordeste e Sudeste do Brasil, com dados de censos agropecuários estaduais de 1975, 1980 e 1985. Teve como itens básicos da modernização tecnológica: a composição da produção agropecuária; a utilização de insumos modernos não mecânicos; a produtividade dos fatores de produção trabalho e terra; a composição do capital fixo e suas taxas de crescimento. Concluiu que o Nordeste continua com o setor agrícola menos modernizado tecnologicamente.

Comparado ao Sudeste, o Nordeste apresentou o predomínio de culturas para "subsistência"; um maior número de estabelecimentos agrícolas considerados grandes e muito grandes; utilização em praticamente todos os estratos de área dos maiores percentuais de gastos com insumos modernos não mecânicos em relação às despesas totais das propriedades; menor produtividade média da terra em valores monetários nos diferentes estratos e uma maior capacidade para geração de recursos de capital. Os investimentos em capital fixo foram maiores na região Sudeste. Com relação ao crédito rural, constatou-se que os estabelecimentos agrícolas da região Sudeste receberam em média um volume de crédito 3,6 vezes maior que os estabelecimentos de áreas equivalentes localizados na região Nordeste. Segundo Paiva (1971), essa falta de uniformidade no grau de modernização entre as regiões Nordeste e Sudeste, conhecido por "dualidade tecnológica", é uma característica da agricultura dos paises em fase de desenvolvimento. $\mathrm{O}$ autor considera que tais países mostram-se muito diferentes quando se comparam os seus agricultores, suas regiões e ainda os produtos agropecuários de uma mesma região.

Apesar da modernização da agricultura nordestina ter ocorrido num grau bastante inferior ao de outras regiões do Brasil, suas conseqüências sobre as economias locais não são muito diferentes. Por exemplo, Landim \& Monteiro (1991) mostram que a elevação dos índices de modernização na microrregião homogênea da Serra de 
Jaboticabal, no Estado de São Paulo, modificou as características do setor rural local. Ocorreram modificações profundas no sistema de produção das unidades agrícolas, na distribuição da posse da terra e nas relações de trabalho. Se antes a concentração era devido à presença de latifúndios com explorações extensivas, agora é explicada com o surgimento e crescimento das grandes empresas agroindustriais. Além disso, a substituição das culturas tradicionais pelas modernas provocou mudanças nas relações de trabalho: a mão-de-obra permanente cedeu lugar ao trabalho assalariado temporário. Do mesmo modo, Carneiro (1982) constatou que as modificações nas relações de produção e emprego na agricultura do Nordeste são reflexos da intensificação do processo de desenvolvimento capitalista no campo. Na região canavieira localizada na zona da Mata, ocorreu a substituição do engenho pela usina, eliminando grande parte dos trabalhadores que antes residiam nos engenhos e que na entressafra se ocupavam com culturas de subsistência. Esses trabalhadores passaram a residir na cidade, empregando-se apenas na época de colheita, ficando a maior parte do ano desocupados ou subocupados. Já nas regiões do Agreste e do Sertão nordestino, a pecuária levou à substituição do algodão arbóreo pelo plantio de capins e palma forrageira. Essa substituição teve efeito de eliminar o arrendamento, resultando em implicações sobre o abastecimento de alimentos e o êxodo rural. $\mathrm{O}$ autor conclui que essas transformações ocorridas na agricultura nordestina "se expressam numa crescente subutilização da força de trabalho, significando também uma mudança de qualidade nesse mercado de trabalho, caracterizado agora pela presença de proletários rurais e pequenos produtores, que são cada vez mais assalariados (Carneiro, 1982, p. 138)".

Adotando uma linha de pobreza de $1 / 4$ de salário mínimo "per capita", Hoffmann (1992) verificou que na atividade agropecuária norte-riograndense $72 \%$ das pessoas eram pobres, e o rendimento médio das mesmas era $50 \%$ menor do que a linha de pobreza. O índice de Sen foi igual a 0,47 , sendo que para eliminar a pobreza, seria necessário redistribuir $37,3 \%$ da renda total das famílias consideradas. $\mathrm{O}$ autor constatou também que entre 1970 e 1980 cresceu a importância das categorias típicas do sistema capitalista de produção, pois decresceu a participação de autônomos e aumentou a de 
empregados e empregadores em todas as regiões do País, ou seja, ocorreu também a modernização das relações de trabalho, vindo assim reafirmar a conclusão de Carneiro.

Analisando a distribuição de renda entre pessoas ocupadas na agricultura brasileira, em cinco regiões, no período de 1981-90, Corrêa \& Hoffmann (1995) verificaram que a pequena produção familiar e os assalariados têm grande importância relativa no Nordeste, representando, respectivamente cerca de $50 \%$ e $45,5 \%$ das pessoas ocupadas na agricultura, mostrando que as relações de trabalho típicas do capitalismo ainda são insignificantes quando comparadas com outras regiões do País. No que se refere ao nível de escolaridade das pessoas ocupadas na agricultura, os autores constataram a necessidade de melhorar o nível de escolaridade da população rural, a fim de aumentar a produtividade do trabalho, pois no Nordeste $88,5 \%$ da população rural tem o primário incompleto. Isso pode explicar, em parte, o baixo nível de produtividade da região.

$\mathrm{Na}$ análise feita pelos autores acima, em décadas diferentes, concluiu-se que o Nordeste continua sendo a região mais pobre do Brasil, com baixos níveis de renda "per capita", que não ultrapassam à metade da média brasileira, além dos elevados níveis de analfabetismo da população rural. Além desses problemas, verifica-se na região uma crescente urbanização da população em decorrência de dificuldades estruturais predominantes no setor rural (elevada concentração fundiária, distribuição desigual de renda, baixa renda "per capita", padrões tecnológicos arcaicos), agravadas periódica e sistematicamente pelos fenômenos de seca ou de enchentes.

Como vimos, são vários os fatores que influenciam o desempenho do setor agrícola de uma região e conseqüentemente no nível de vida da população. E é por isso que o desempenho da agricultura sempre será uma preocupação constante dos formuladores de políticas, devido a sua relevância no desenvolvimento econômico do País. Além disso, o bom dinamismo do setor pode favorecer o aumento do emprego e renda rurais, e também conduzir a uma redução da migração rural-urbana.

Diversos estudos sobre desempenho e diferenças regionais de crescimento agrícola utilizaram o modelo "shift-share" para quantificar as fontes de crescimento da agricultura num determinado período. Patrick (1975) utilizou uma versão modificada 
desse modelo para medir as fontes de crescimento na agricultura nacional, regional, estadual e interculturas no Brasil, no período 1948 a 1969. Os resultados encontrados indicaram grandes diferenças entre as culturas no País e entre grupos de produtos dentro de cada região. As fontes de crescimento diferiram substancialmente entre Estados e regiões. Concluiu que o aumento da produção estava fortemente associado ao efeito área e, em segundo plano, ao efeito rendimento. À mesma conclusão chegou Yokoyama (1988), ao analisar as transformações ocorridas no setor primário goiano no período de 1975-84. Constatou que no período 1975-80 o efeito área foi o que mais contribuiu para expansão da produção, e no segundo período 1980-84 o principal efeito explicativo da taxa média anual de crescimento foi o efeito composição das culturas, devido, principalmente, ao crescimento da soja e cana-de-açúcar.

Da mesma maneira Igreja et al. (1983), ao analisar as fontes de variação da agricultura paulista por região e culturas individuais, no período de 1966 a 1977, constataram que o efeito-área foi o grande responsável pela expansão na produção em todos os níveis da análise, aparecendo a estrutura de cultivo como segundo fator explicativo dessas variações, o que indica diferença da produção agrícola no sentido de crescimento mais rápido dos produtos industrializáveis e exportáveis.

Já Fassarella (1987), ao analisar o padrão de crescimento do setor de culturas do Estado do Espírito Santo na década de 70, concluiu, dentre as variáveis explicativas da taxa de crescimento do produto agrícola e dos municípios, que o efeito rendimento foi o mais importante em todos os períodos analisados, indicando que a agricultura capixaba teria sentido os efeitos das políticas de modernização, pesquisa e de crédito subsidiado, ou também da escassez de áreas disponíveis. Esse resultado contrasta com as conclusões obtidas nos outros Estados, nos quais o efeito-área foi o grande responsável pela expansão da produção, tanto na década de 60 como na de 70 . O resultado comum a todos foi a preferência das culturas de exportação e industrializáveis em relação às de mercado interno, o que pode ser atribuído aos incentivos à exportação.

Para analisar o comportamento da utilização do solo agrícola, Zockun (1978) desenvolveu um método descritivo, que na sua essência, é semelhante ao modelo "shift-share". Esse método procura identificar, na alteração da área total utilizada pela 
atividade agropecuária, a parcela devida à escala do sistema de produção e a parte devida à substituição dentro do sistema. Analisando a expansão da soja no Brasil, no período de 1970/73, Zockun concluiu que a expansão da soja foi devida mais ao efeito substituição ( $88 \%)$ do que ao efeito escala (12\%).

Esse modelo foi modificado por Camargo (1983) e utilizado em dois estudos (Camargo, 1983 e Camargo et al., 1995) para analisar as alterações ocorridas nos padrões de cultivo das Divisões Regionais Agrícolas (DIRAs) do Estado de São Paulo, nos períodos de 1968/69 a 1979/80 e 1983/93, através da análise comparativa entre as culturas exportáveis, de mercado interno e pastagens. Os resultados permitem constatar que, tanto na década de 70 como na de 80 , as culturas voltadas para o mercado interno e as pastagens reduziram suas áreas, ao contrário do que ocorreu com os produtos exportáveis. Um exemplo disso está nos 2,83 milhões de hectares cedidos principalmente por pastagem natural, café, reflorestamento, arroz, feijão, algodão, amendoim e milho, no período de $1983-93$, dos quais $96,8 \%$ foram incorporados por atividades de maior rentabilidade econômica como: pastagem cultivada, laranja, cana para indústria e soja. Em todas as regiões observaram-se mudanças na composição das atividades e na intensificação de especialização.

Utilizando a mesma metodologia acima, tanto Gasques \& Villa Verde (1990) como Olivetti \& Camargo (1992) avaliaram o crescimento da agricultura brasileira e o relacionaram com as políticas agrícolas dos anos setenta e oitenta. Chegaram à conclusão de que, a partir dos anos 70 , a composição da produção agrícola brasileira foi influenciada por alterações nas políticas agrícolas que visavam à modernização do setor através do crédito subsidiado, e os principais beneficiários foram os produtos destinados à exportação e os substitutos energéticos. Na década de 80 , constatou-se que as culturas de mercado interno foram substituídas pelas culturas de mercado mais estável e lucrativo. Apesar dos preços reais terem sido decrescentes na década 80, a produção agrícola cresceu. Segundo os autores, esse crescimento pode ter ocorrido devido às mudanças da composição de produção (isto é, troca de produtos de maior valor comercial), ganhos de produtividade, redução dos custos dos insumos e políticas governamentais de sustentação do setor. Especificamente analisando a região 
Nordeste, Gasques e Villa Verde concluiram que os produtos tradicionais como algodão arbóreo e herbáceo e mandioca foram substituídos por produtos de maior valor como soja, milho e feijão. Na década de 80 ocorreu também uma retração absoluta das áreas das lavouras, devido ao efeito escala negativo. Concluíram também que as principais transformações com relação à pesquisa agronômica e animal ocorreram nas regiões Centro-Oeste e Nordeste.

As considerações realizadas até agora, com base nos vários trabalhos citados, servirão como referencial a ser testado através da análise do processo de transformações ocorridos no setor de culturas do Estado do Rio Grande do Norte. Essa análise contribuirá para ampliar os conhecimentos do processo de transformação da agricultura no Estado, identificando a tendência ou especialidades de cada microrregião, permitindo verificar os possíveis efeitos dos diversos programas e políticas da região, auxiliando, assim, nas formulações das futuras políticas de planejamento e pesquisa agrícola. 


\section{MATERIAL E MÉTODO}

\section{1 Área de estudo}

O presente trabalho abrange o Estado do Rio Grande do Norte e suas microrregiões. De acordo com a divisão da Fundação Instituto Brasileiro de Geografia e Estatística (IBGE), os municípios que apresentam características socioeconômicas e edafo-climáticas semelhantes, dentro do Estado, foram agrupados em microrregiões homogêneas. Assim, a análise foi feita por microrregião homogênea, a saber: Salineira Norte-riograndense (MR-1); Litoral de São Bento do Norte (MR-2); Açu e Apodi (MR-3); Sertão de Angicos (MR-4); Serra Verde(MR-5); Natal (MR-6); Serrana Norte-riograndense(MR-7); Seridó (MR-8); Borborema Potiguar (MR-9) e Agreste Potiguar(MR-10), podendo ser visualizadas na Figura 1. Os municípios que compõem cada microrregião estão relacionados no Apêndice 1.

O Rio Grande do Norte está situado no extremo oriental do País, abrangendo uma superfície de $53.015 \mathrm{~km}^{2}$, correspondendo a $0,62 \%$ do território nacional, formado por 153 municípios. Limita-se ao norte e a leste com o Oceano Atlântico, ao sul com o Estado da Paraíba e a oeste com o Estado do Ceará.

O clima do Estado apresenta uma temperatura média elevada $\left(27^{\circ} \mathrm{C}\right)$ e um regime pluviométrico irregular, isto é, além de ser constituída por baixos índices de chuva, apresenta instabilidade anual e interanual, além dos altos índices de evapotranspiração. Possui quatro tipos de clima que podem ser melhor visualizados na Figura 2: clima árido em $18 \%$ da superficie estadual, tendo uma cota pluviométrica anual de 430 milímetros; clima semi-árido, perfazendo uma área de $57 \%$ do Estado, apresentando cotas pluviométricas que variam de 570 a $850 \mathrm{~mm} / \mathrm{ano}$; clima subúmido seco, que se encontra em parte do litoral oriental e nas áreas serranas do interior, abrangendo $20 \%$ da área estadual; e por fim, o clima úmido em $5 \%$ da área estadual. 


\section{MICRORREGIÖES}

MR-1 - Salineira Norte-riograndense

MR-2 - Litoral de São Bento do Norte

MR-3 - Açu e Apodi

MR-4 -Sertão de Angicos

MR-5 - Serra Verde

MR-6 - N ata1

MR-7 - Serrana Norte-riograndense

MR-8 - Seridó

MR-9 - Borborema Potiguar

MR-10 - Agre ste Potiguar

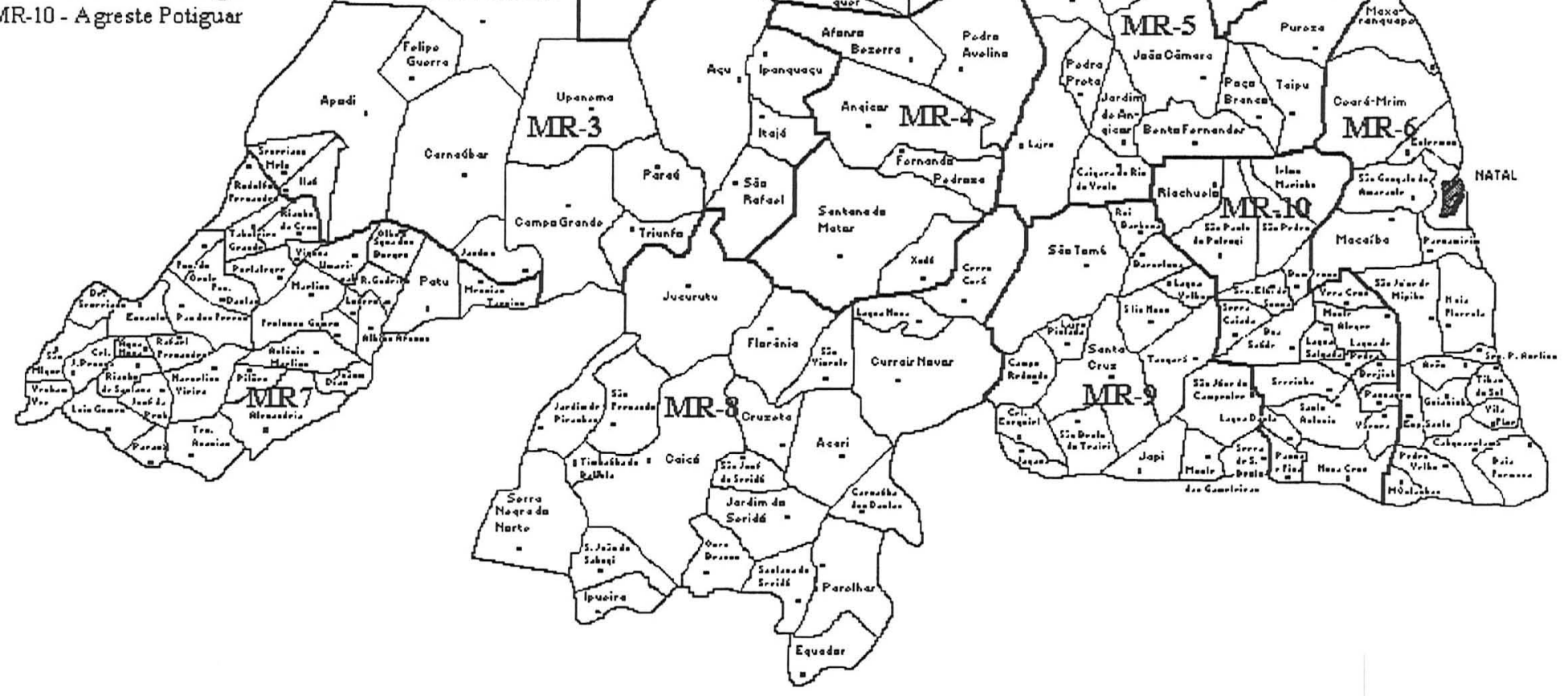

FIGURA 1 - Microrregiões homogêneas do Estado do Rio Grande do Norte 


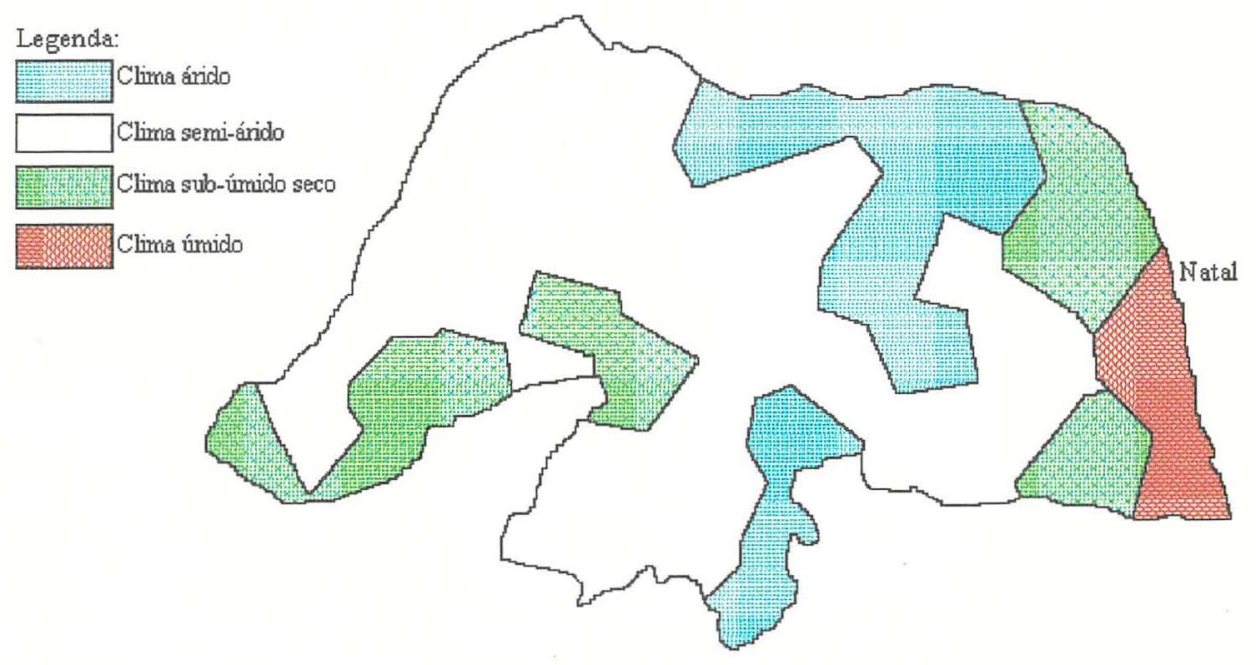

Figura 2 - Tipos de clima do Estado do Rio Grande do Norte

A área estadual abrangida pelo "polígono das secas" é de $48.031 \mathrm{~km}^{2}$, representando $90,6 \%$ da área total do Estado e 5,13\% do total das áreas abrangidas pelo polígono (FIDEC, 1981). No Nordeste, mais especificamente no Rio Grande do Norte, a seca não se caracteriza tanto pela falta de chuva, mas sim pela sua irregularidade e pelos elevados índices de evapotranspiração.

A vegetação estadual é pouco diversificada, com quase $80 \%$ do território coberto por caatinga ${ }^{1}$. Os outros $20 \%$ são compostos por floresta seca, floresta úmida costeira (ou Mata Atlântica) e vegetação litorânea, conhecida como vegetação dos mangues (Figura 3).

A estrutura geológica estadual é composta pelo embasamento cristalino, que cobre $60 \%$ da superfície da porção centro-meridional do Estado e pela área sedimentar no restante da superficie estadual. A primeira, dada sua pouca

1 Caatingas são arbustos que se destacam pela grande resistência às secas, possuindo meios protetores contra o excesso de transpiração, tornando-os imunes às estiagens prolongadas (6 a 11 meses). 
permeabilidade, favorece o potencial hídrico superficial, isto é, condiciona a construção de infra-estruturas de açudagem, a perenização de cursos de água; a segunda, contorna todo litoral estadual com solos profundos e permeáveis, favorecendo o potencial hídrico subterrâneo, como a perfuração de poços.

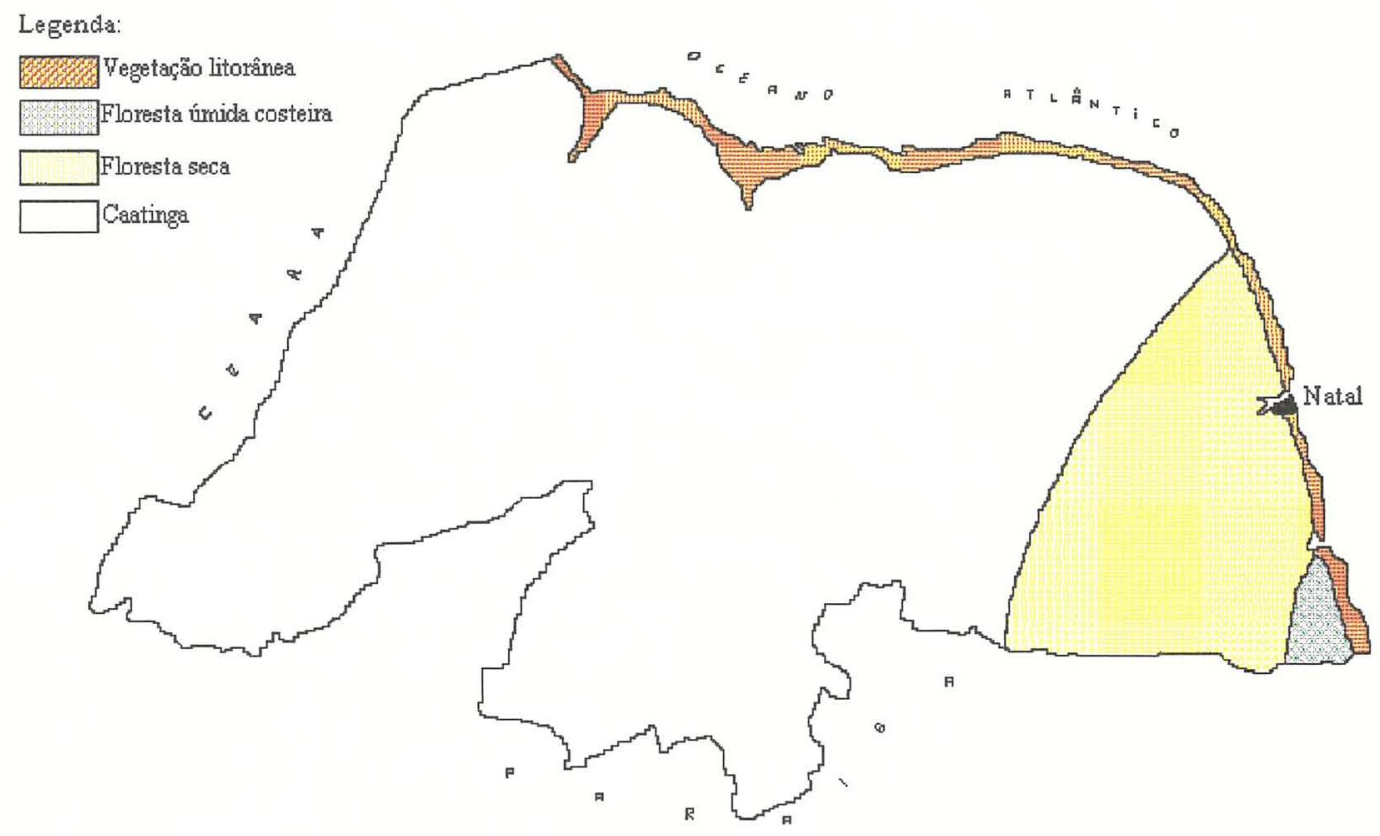

Figura 3 - Tipos de vegetação do Estado do Rio Grande do Norte

Com relação à água superficial, as bacias do Piranhas-Açu e ApodiMossoró são as principais, cobrindo cerca de $80 \%$ da área estadual (Figura 4). O Estado apresenta um déficit permanente d'água, devido principalmente à escassez e irregularidade das chuvas e os altos índices de evapotranspiração, fazendo com que a maior parte dos seus rios tenham um regime intermitente.

O Estado do Rio Grande do Norte possui uma grande variedade de solos, destacando-se entre os mais representativos: o litólico eutrófico que domina a parte oriental do Seridó devido a sua pedregosidade e profundidade, não é indicado para cultivos intensivos, podendo ser utilizado com a pecuária; o bruno não cálcico localizado na parte ocidental do Seridó, que apresenta limitações quanto a sua profundidade, o teor 


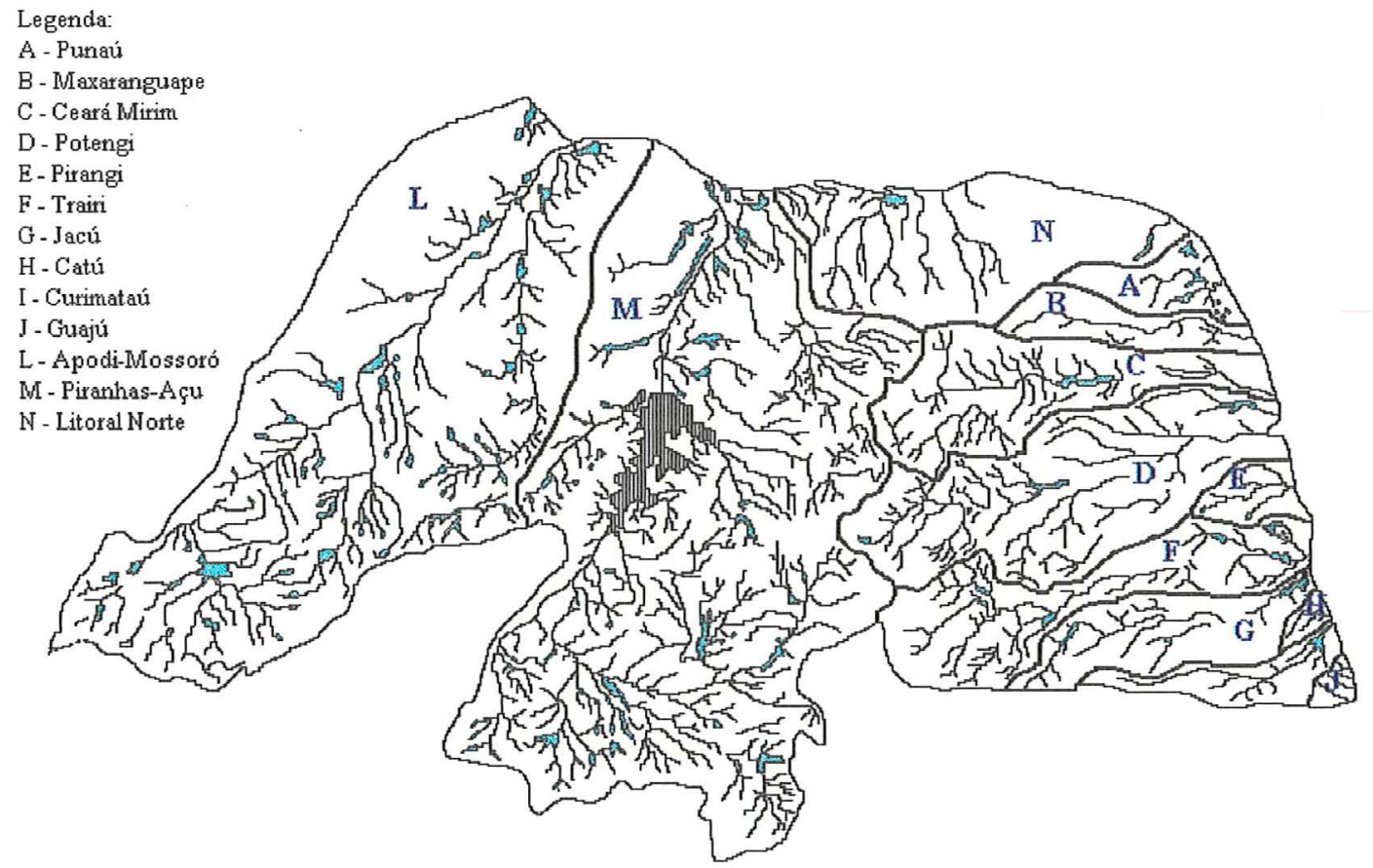

Figura 4 - Bacias hidrográficas do Estado do Rio Grande do Norte

de salinização e presença de pedras, sendo, portanto, mais indicado para a pecuária e a lavoura seca; o podzólico vermelho amarelo, localizado no extremo sudoeste, possuindo uma textura argilosa e média, e é profundo, bem drenado, com relevo variando de plano a ondulado, se prestando para lavoura, inclusive irrigada, dependendo da disponibilidade de água. E na área do clima semi-árido é aproveitado com pastagens. O latosol vermelho amarelo eutrófico, localizado na Chapada do Apodi, profundo, bem drenado e de relevo plano e suavemente ondulado, possuindo fertilidade baixa, sofre o problema de aridez e apresenta baixa retenção de umidade, podendo ser utilizado com culturas. No agreste, tem-se o planosol solódico, moderadamente profundo, textura argilosa e arenosa, com drenagem de moderada a imperfeita, devido aos altos teores de sódio é mais indicado para pecuária; e as areias quartzosas que são apropriadas para vegetação permanente (Figura 5).

Diante dessa descrição, pode-se perceber que o setor agropecuário norteriograndense é bastante influenciado pelo caráter de anormalidade climática, agravado 
pela limitada quantidade dos recursos de solos para fins agrícolas. Portanto, o desenvolvimento da agricultura depende do meio físico em que se encontra.

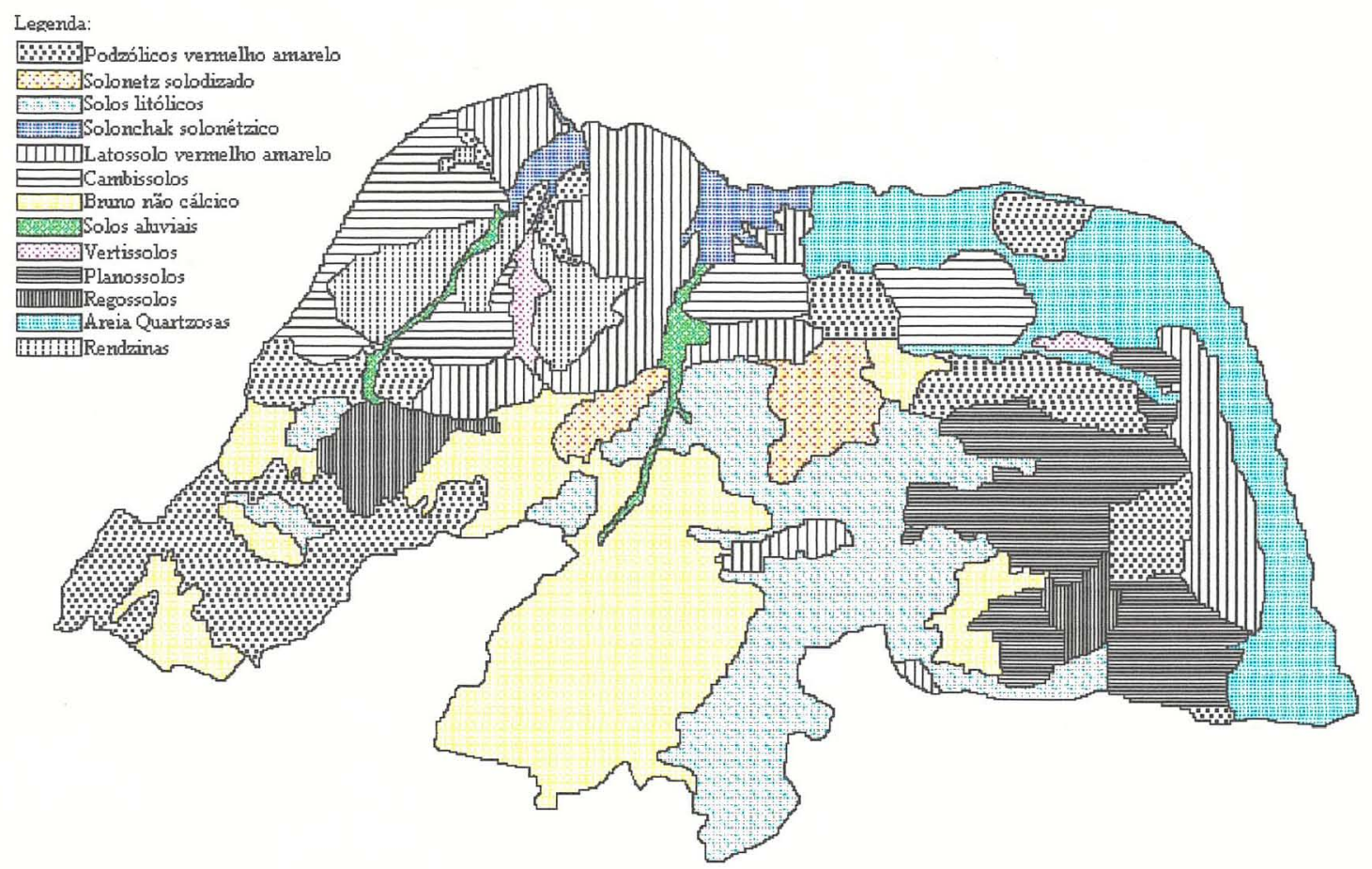

Figura 5 - Solos do Estado do Rio Grande do Norte

As descrições da estrutura física, localização, superficie, clima, recursos hídricos, solos e vegetação por microrregiões do Rio Grande do Norte estão detalhadas no Apêndice 2 (Tabelas 2.1 e 2.2), auxiliando o entendimento do processo produtivo da região. Na descrição dos solos estão especificados os principais tipos em cada microrregião, dando ênfase aos níveis de exigência de fertilizantes, mecanização e aptidão agrícola $^{2}$.

${ }^{2}$ Essa análise sucinta foi extraída de diversas publicações, tais como: Recursos naturais renováveis: água e solos (FIDEC, 1983); Perfil do Estado do Rio Grande do Norte (FIDEC, 1993); Aptidão agrícola das terras do Estado do Rio Grande do Norte (Ministério da Agricultura, 1978) e Levantamento exploratório - Reconhecimento de solos do Estado do Rio Grande do Norte (BRASIL, 1971). 
As tabelas 3 e 4 mostram as participações percentuais das principais culturas nas microrregiões em relação à área total cultivada por cada cultura no Estado, para os anos agrícolas de 1981 e 1992. Percebe-se que a participação da área plantada do algodão arbóreo e herbáceo diminuiu em quase todas as microrregiões, ao contrário do que ocorreu com o caju. Já a produção da cana-de-açúcar concentra-se na microrregião de Natal e a do coco-da-baía nas regiões de Natal e Litoral de São Bento do Norte, onde também estão as principais agroindústrias de transformação industrial. Também verifica-se que o feijão, milho, mandioca e a batata-doce são cultivadas em todas as microrregiões e que as regiões Salineira Norte-riograndense e Açu-Apodi respondiam no final do período por praticamente toda produção estadual de melão.

\subsection{Metodologia}

\subsubsection{Descrição do Modelo "Shift-Share"}

O modelo "shift-share", também conhecido como "diferencial-estrutural", será utilizado para medir as fontes de crescimento das principais culturas do setor agrícola do Estado do Rio Grande do Norte e microrregiões. Esse método explica o crescimento das culturas por dois componentes: o estrutural, que está ligado à composição setorial das atividades da região e o diferencial, ligado às vantagens locacionais comparativas.

No presente estudo, esse método foi utilizado para separar a variação da produção em quatro efeitos ou quatro fontes explicativas de crescimento, que são: 1) variações na área cultivada (efeito área - EA);

2) variações no rendimento das culturas (efeito rendimento - ER);

3) variações na localização geográfica (efeito localização geográfica - ELG) e 4) mudanças na composição da produção regional (efeito composição - EC).

Os quatro efeitos são incluídos na análise do crescimento da produção do conjunto de culturas no Estado. Ao analisar individualmente cada cultura no Estado, pode-se distinguir os efeitos área, rendimento e localização geográfica. E na análise do crescimento do valor da produção das culturas em cada microrregião, o modelo opera sobre as variações na área cultivada, no rendimento e na composição da produção. Esses 
efeitos são obtidos através das variações desses componentes no tempo. Esta análise não considera as interações entre as fontes de crescimento.

Tabela 3 - Participação percentual das microrregiões Salineira Norte-riograndense, Litoral de São Bento do Norte, Açu-Apodi, Sertão Angicos e Serra Verde na área total cultivada de cada cultura do Estado do Rio Grande do Norte, 1981 e 1992.

\begin{tabular}{|c|c|c|c|c|c|c|c|c|c|c|}
\hline \multirow{3}{*}{ Culturas } & \multicolumn{10}{|c|}{ Microrregiões (\%) } \\
\hline & \multicolumn{2}{|c|}{ Salineira } & \multicolumn{2}{|c|}{ Litoral São Bento } & \multicolumn{2}{|c|}{ Açu-Apodi } & \multicolumn{2}{|c|}{ Sertão Angicos } & \multicolumn{2}{|c|}{ Serra Verde } \\
\hline & 1981 & \begin{tabular}{|l|}
1992 \\
\end{tabular} & 1981 & 1992 & 1981 & 1992 & 1981 & 1992 & 1981 & 1992 \\
\hline Abacaxi & 0,0 & 0,0 & 3,1 & 29,4 & 0,0 & 0,0 & 0,0 & 0,0 & 18,0 & 23,0 \\
\hline Algodão herbáceo & 10,6 & 27,7 & 3,0 & 1,5 & 15,4 & 29,5 & 1,4 & 4,2 & 7,5 & 4,2 \\
\hline Arroz & 0,4 & 0,7 & 0,0 & 0,0 & 16,2 & 24,6 & 0,0 & 0,0 & 0,0 & 0,0 \\
\hline Batata doce & 7,1 & 3,2 & 1,0 & 3,6 & 20,2 & 7,2 & 0,8 & 0,8 & 0,7 & 1,8 \\
\hline Cana-de-açúcar & 0,0 & 0,0 & 0,0 & 0,3 & 0,6 & 0,0 & 0,0 & 0,0 & 0,6 & 6,2 \\
\hline Feijão & 3,9 & 8,8 & 1,4 & 1,9 & 22,3 & 10,5 & 4,3 & 8,3 & 4,1 & 5,1 \\
\hline Mandioca & 0,2 & 3,0 & 1,6 & 5,9 & 0,7 & 0,4 & 1,0 & 1,1 & 3,1 & 8,1 \\
\hline Melão & 69,0 & 75,9 & 0,0 & 0,0 & 19,6 & 20,7 & 0,2 & 0,5 & 0,0 & 0,0 \\
\hline Milho & 5,2 & 8,4 & 1,1 & 2,3 & 14,8 & 7,3 & 0,9 & 6,5 & 2,4 & 5,4 \\
\hline Sorgo & 60,1 & 31,2 & 0,0 & 15,6 & 14,2 & 3,9 & 7,6 & 17,1 & 9,2 & 24,1 \\
\hline Algodão Arbóreo & 3,6 & 0,0 & 1,6 & 0,0 & 6,7 & 0,6 & 15,3 & 12,5 & 6,0 & 11,1 \\
\hline Banana & 5,9 & 5,5 & 2,2 & 3,1 & 12,1 & 12,3 & 1,1 & 1,2 & 3,3 & 5,5 \\
\hline Caju & 78,9 & 40,7 & 0,3 & 11,7 & 12,9 & 13,4 & 0,0 & 0,8 & 0,2 & 9,3 \\
\hline Coco-da-baía & 3,4 & 1,5 & 31,5 & 51,2 & 1,2 & 0,4 & 0,3 & 0,1 & 2,0 & 4,7 \\
\hline Manga & 0,8 & 1,5 & 3,3 & 3,2 & 5,2 & 24,3 & 0,6 & 0,2 & 3,7 & 7,8 \\
\hline Sisal & 0,0 & 0,0 & 44,5 & 2,7 & 0,0 & 0,0 & 0,0 & 0,0 & 40,0 & 51,4 \\
\hline
\end{tabular}

Fonte: Dados básicos do Anuário Estatístico do Rio Grande do Norte de 1982 e 1995. 
Tabela 4 - Participação percentual das microrregiões de Natal, Serrana Norteriograndense, Seridó, Borborema Potiguar e Agreste Potiguar na área total cultivada de cada cultura do Estado do Rio Grande do Norte, 1981 e 1992.

\begin{tabular}{l|ccc|c|c|c|c|c|c|c|c}
\hline \multirow{2}{*}{\multicolumn{1}{c}{ Culturas }} & \multicolumn{10}{c}{ Microrregiões (\%) } \\
\cline { 2 - 13 } & \multicolumn{3}{|c}{ Natal } & \multicolumn{2}{c}{ Serrana } & \multicolumn{2}{c}{ Seridó } & \multicolumn{2}{c}{ Borborema } & \multicolumn{2}{c}{ Agreste } \\
\cline { 2 - 13 } & 1981 & 1992 & 1981 & 1992 & 1981 & 1992 & 1981 & 1992 & 1981 & 1992 \\
\hline Abacaxi & 33,6 & 10,3 & 0,0 & 0,0 & 0,0 & 0,0 & 0,0 & 0,0 & 45,3 & 37,2 \\
Algodão herbáceo & 1,2 & 0,3 & 20,0 & 17,0 & 0,8 & 0,6 & 12,9 & 8,1 & 27,3 & 6,7 \\
Arroz & 0,0 & 0,5 & 37,2 & 49,0 & 46,2 & 25,2 & 0,0 & 0,0 & 0,0 & 0,0 \\
Batata doce & 14,8 & 33,4 & 2,5 & 5,4 & 41,4 & 22,5 & 0,0 & 3,3 & 11,4 & 18,9 \\
Cana-de-açúcar & 94,7 & 90,2 & 2,8 & 1,5 & 0,6 & 0,3 & 0,0 & 0,0 & 0,8 & 1,6 \\
Feijão & 3,5 & 4,9 & 20,8 & 12,6 & 21,7 & 7,2 & 6,6 & 22,6 & 11,5 & 18,0 \\
Mandioca & 17,6 & 14,6 & 4,6 & 3,2 & 7,5 & 8,7 & 6,7 & 10,7 & 57,2 & 44,2 \\
Melão & 5,3 & 1,0 & 0,0 & 1,0 & 5,9 & 0,7 & 0,0 & 0,2 & 0,0 & 0,0 \\
Milho & 5,9 & 3,9 & 29,0 & 22,6 & 23,7 & 12,3 & 3,0 & 15,5 & 14,1 & 15,7 \\
Sorgo & 0,1 & 0,0 & 0,1 & 0,0 & 7,9 & 0,6 & 0,5 & 6,9 & 0,2 & 0,6 \\
Algodão Arbóreo & 0,0 & 0,0 & 19,5 & 18,8 & 24,3 & 54,5 & 22,9 & 2,5 & 0,2 & 0,0 \\
Banana & 47,7 & 52,5 & 10,1 & 9,3 & 8,5 & 4,1 & 1,8 & 1,9 & 7,3 & 4,8 \\
Caju & 6,6 & 11,8 & 0,2 & 5,0 & 0,5 & 2,4 & 0,0 & 2,1 & 0,3 & 2,8 \\
Coco-da-baía & 53,6 & 37,6 & 1,2 & 0,5 & 2,1 & 0,8 & 0,7 & 0,4 & 4,1 & 2,8 \\
Manga & 52,9 & 42,4 & 13,9 & 5,6 & 5,6 & 6,1 & 0,0 & 0,1 & 13,9 & 8,8 \\
Sisal & 0,0 & 0,0 & 0,0 & 0,0 & 4,4 & 0,0 & 10,5 & 45,9 & 0,6 & 0,0 \\
\hline
\end{tabular}

Fonte: Dados básicos do Anuário Estatístico do Rio Grande do Norte de 1982 e 1995.

O efeito área indica mudanças na produção devido a variações na área cultivada, supondo que o rendimento, a localização geográfica e a estrutura de cultivo permaneçam constantes.

$\mathrm{O}$ efeito rendimento mede a alteração na produção decorrente de modificação na produtividade da terra, mantidas as outras fontes de crescimento inalteradas. Esta modificação na produtividade pode refletir mudanças tecnológicas 
com a introdução de novos insumos e técnicas de produção e melhoria do capital humano.

O efeito localização geográfica reflete variações na produção decorrentes de mudanças na localização das culturas entre as microrregiões estudadas, mantidas as demais variáveis constantes.

O efeito composição mostra variações na produção decorrentes de mudanças na estrutura produtiva, ou seja, mudanças na proporção da área total utilizada para o plantio das diversas culturas estudadas, mantidos constantes o rendimento e a área total cultivada. As culturas de menor rentabilidade são substituídas pelas culturas de maior rentabilidade por unidade de área.

\subsubsection{Variáveis utilizadas}

Nesse item estão detalhados os diversos subíndices e variáveis que serão utilizados no modelo "shift-share".

$\mathrm{O}$ subíndice $\mathbf{c}$ indica a cultura, variando de 1 a $\mathbf{n}$. Este $\mathbf{n}$ varia de acordo com os conjuntos de culturas específicas para cada microrregião estudada.

O subíndice $\mathbf{m}$ indica a microrregião, variando de 1 a $\mathbf{k}(\mathrm{k}=10)$.

$\mathrm{O}$ subíndice $\mathbf{t}$ define o período de tempo, que vai de zero a $\mathbf{f}$. O período inicial é definido pelo índice 0 e o período final é definido por $\mathbf{f}$.

As variáveis são as que seguem:

$\mathrm{Q}_{\mathrm{ct}}=$ quantidade produzida da c-ésima cultura no Estado do Rio Grande do Norte, no período $t$;

$\mathrm{V}_{\mathrm{t}}=$ valor da produção das culturas no Estado do Rio Grande do Norte, utilizando preços médios do triênio 1991-93, no período t, em cruzeiros reais;

$\mathrm{V}_{\mathrm{mt}}=$ valor da produção das culturas na m-ésima microrregião do Estado, no período t, em cruzeiros reais;

$\mathrm{AT}_{\mathbf{t}}=$ área total cultivada das culturas (dimensão do sistema de produção) no Estado, no período t, em hectares;

$\mathrm{AT}_{\mathrm{cmt}}=$ área total cultivada da c-ésima cultura, na m-ésima microrregião, no período t, em hectares; 
$\mathrm{AT}_{\mathrm{mt}}=$ área total cultivada das culturas, na m-ésima microrregião do Estado, no período t, em hectares;

$\mathrm{AT}_{\mathrm{ct}}=$ área total cultivada da c-ésima cultura no Estado, no período $\mathrm{t}$, em hectares;

$\mathrm{R}_{\mathrm{cmt}}=$ rendimento da c-ésima cultura, na m-ésima microrregião do Estado, no período $\mathrm{t}$, em $\mathrm{kg} / \mathrm{ha}$, frutos/ha ou cachos/ha;

$\mathrm{P}_{\mathbf{c}} \quad=$ preço médio, por unidade do produto da c-ésima cultura, pago ao produtor no triênio 1991-93, no Estado, em cruzeiros reais;

$\alpha_{m t}=$ proporção da área total cultivada na m-ésima microrregião na área total cultivada do Estado $\left(\mathrm{AT}_{\mathrm{ml}} / \mathrm{AT}_{\mathrm{t}}\right)$, no período $\mathrm{t}$;

$\beta_{c m t}=$ proporção da área cultivada com a c-ésima cultura na m-ésima microrregião, na área total na m-ésima microrregião do Estado $\left(\mathrm{AT}_{\mathrm{cml}} / \mathrm{AT}_{\mathrm{mt}}\right)$, no período $\mathrm{t}$;

$\gamma_{c m t}=$ proporção da área total cultivada da c-ésima cultura na m-ésima microrregião, na área cultivada da c-ésima cultura $\left(\mathrm{AT}_{\mathrm{cmt}} / \mathrm{AT}_{\mathrm{ct}}\right)$, no período t, no Estado;

$\lambda=$ coeficiente que mede a modificação na área total cultivada das culturas (dimensão do sistema) entre os períodos 0 (inicial) e f(final), $\left(\mathrm{AT}_{\mathrm{f}} / \mathrm{AT}_{0}\right)$.

\subsubsection{Decomposição da variação na produção}

Neste item será descrita a decomposição da variação na produção, utilizando o modelo "shift-share", em diversos níveis de análise. O item está subdividido da seguinte maneira: a) análise por cultura no Estado; b) análise do conjunto de culturas em cada microrregião e c) análise do conjunto de culturas no Estado.

\subsubsection{Análise por cultura no Estado}

No período inicial, a quantidade produzida da c-ésima cultura $\left(\mathrm{Q}_{\mathrm{co}}\right)$ para o Estado do Rio Grande do Norte é dada por:

$$
Q_{c 0}=\sum_{m=1}^{k} A T_{c m 0} R_{c m 0}=\sum_{m=1}^{k} \gamma_{c m 0} A T_{c 0} R_{c m 0}
$$


Se $\mathrm{AT}_{\mathrm{cmf}}$ e $\mathrm{R}_{\mathrm{cmf}}$ são, respectivamente, área cultivada e rendimento para essa cultura na m-ésima microrregião no período final (f), então a quantidade produzida da c-ésima cultura no período final $\left(Q_{\mathrm{cf}}\right)$ é definida por:

$$
Q_{c f}=\sum_{m=1}^{k} A T_{c m f} R_{c m f}=\sum_{m=1}^{k} \gamma_{c m f} A T_{c f} R_{c m f}
$$

Se no período analisado, se altera apenas a área total cultivada da cultura no Estado, a produção final $\left(Q_{c f}^{A T}\right)$ será:

$$
Q_{c f}^{A T}=\sum_{m=1}^{k} \gamma_{c m 0} A T_{c f} R_{c m 0}
$$

Se área e rendimento variam, permanecendo constante a localização da produção e a estrutura do cultivo, a quantidade produzida no período f $\left(Q_{c f}^{A T R}\right)$, será:

$$
Q_{c f}^{A T R}=\sum_{m=1}^{k} \gamma_{c m 0} A T_{c f} R_{c m f}
$$

Por último, variando área, rendimento e localização geográfica, a produção no período final $\left(Q_{c f}^{A T R \gamma}=Q_{c f}\right)$ é dada por:

$$
Q_{c f}^{A T R \gamma}=\sum_{m=1}^{k} \gamma_{c m f} A T_{c f} R_{c m f}=Q_{c f}
$$

A mudança total na quantidade produzida da c-ésima cultura, do período inicial (0) para o período final (f) $\left(\mathrm{Q}_{\mathrm{cf}}-\mathrm{Q}_{\mathrm{c} 0}\right)$, será:

$$
Q_{c f}-Q_{c 0}=\sum_{m=1}^{k} \gamma_{c m f} A T_{c m f} R_{c m f}-\sum_{m=1}^{k} \gamma_{c m 0} A T_{c 0} R_{c m} 0
$$

que também pode ser expressa da seguinte forma:

$$
Q_{c f}-Q_{c 0}=\left(Q_{c f}^{A T}-Q_{c 0}\right)+\left(Q_{c f}^{A T R}-Q_{c f}^{A T}\right)+\left(Q_{c f}-Q_{c f}^{A T R}\right)
$$

em que: 


$$
\begin{aligned}
\left(Q_{c f}^{A T}-Q_{c 0}\right)= & \text { variação total na quantidade produzida da c-ésima cultura } \\
& \text { entre } 0 \mathrm{e} \mathrm{f}, \text { quando somente a área total cultivada se altera, } \\
& \text { que se denomina efeito área (EA); } \\
\left(Q_{c f}^{A T R}-Q_{c f}^{A T}\right)= & \text { variação total na quantidade produzida da c-ésima cultura } \\
& \text { entre } 0 \text { e } \mathrm{f} \text {, quando varia o rendimento, e as demais } \\
& \text { variáveis permanecem constantes, que se denomina efeito } \\
& \text { rendimento (ER); } \\
\left(Q_{c f}-Q_{c f}^{A T R}\right)= & \text { variação total na quantidade produzida da c-ésima cultura } \\
& \text { entre } 0 \text { e } \mathrm{f}, \text { devido à mudança da localização geográfica, } \\
& \text { mantidas constantes as demais variáveis, que se denomina } \\
& \text { efeito localização geográfica (ELG). }
\end{aligned}
$$

Como se pode verificar, na análise das culturas individuais no Estado não existe efeito composição, a mudança total na quantidade produzida da c-ésima cultura é diferenciada em efeitos área, rendimento e localização geográfica.

\subsection{Apresentação dos resultados: taxas anuais de crescimento}

$\mathrm{Na}$ apresentação dos resultados, foi usada a metodologia proposta por Igreja (1987), utilizada por Yokoyama (1988) e Cardoso (1996). Os valores dos efeitos isolados encontrados foram apresentados na forma de taxas anuais de crescimento, sendo, portanto, expressos individualmente como uma percentagem da mudança total na produção.

Multiplicando ambos os lados da equação (7) por:

$$
\frac{1}{\left(Q_{c f}-Q_{c 0}\right)}
$$

tem-se a seguinte identidade

$$
1 \equiv \frac{\left(Q_{c f}^{A T}-Q_{c 0}\right)}{\left(Q_{c f}-Q_{c 0}\right)}+\frac{\left(Q_{c f}^{A T R}-Q_{c f}^{A T}\right)}{\left(Q_{c f}-Q_{c 0}\right)}+\frac{\left(Q_{c f}-Q_{c f}^{A T R}\right)}{\left(Q_{c f}-Q_{c 0}\right)}
$$


Multiplicando-se ambos os lados da identidade (8) por:

$$
r=\left(\sqrt[f]{\frac{Q_{c f}}{Q_{c 0}}}-1\right) 100
$$

em que $r$ é a taxa anual média de variação na produção da c-ésima cultura, em porcentagem, obtém-se a seguinte expressão:

$r=\frac{\left(Q_{c f}^{A T}-Q_{c 0}\right)}{\left(Q_{c f}-Q_{c 0}\right)} r+\frac{\left(Q_{c f}^{A T R}-Q_{c f}^{A T}\right)}{\left(Q_{c f}-Q_{c 0}\right)} r+\frac{\left(Q_{c f}-Q_{c f}^{A T R}\right)}{\left(Q_{c f}-Q_{c 0}\right)} r$

em que:

$$
\begin{aligned}
& \frac{\left(Q_{c f}^{A T}-Q_{c 0}\right)}{\left(Q_{c f}-Q_{c 0}\right)} r=\begin{array}{l}
\text { efeito área (EA), expresso em taxa de crescimento ao ano, em } \\
\text { percentagem; }
\end{array} \\
& \frac{\left(Q_{c f}^{A T R}-Q_{c f}^{A T}\right)}{\left(Q_{c f}-Q_{c 0}\right)} r=\begin{array}{l}
\text { efeito rendimento (ER), expresso em taxa de crescimento ao } \\
\text { ano, em percentagem; }
\end{array} \\
& \frac{\left(Q_{c f}-Q_{c f}^{A T R}\right)}{\left(Q_{c f}-Q_{c 0}\right)} r=\begin{array}{l}
\text { efeito localização geográfica (ELG), expresso em taxa de } \\
\text { crescimento ao ano, em percentagem. }
\end{array}
\end{aligned}
$$

\subsection{Decomposição do efeito área (efeitos escala e substituição)}

Para se analisar as alterações na composição da área cultivada no Estado do Rio Grande do Norte e suas microrregiões em períodos distintos foi utilizado o modelo desenvolvido por Zockun (1978), que parte do pressuposto de que a área cultivada com uma determinada cultura num determinado período, dentro do sistema de produção, pode se alterar devido a dois efeitos:

a) "escala": é a variação da área total do sistema de produção (isto é, total da área das culturas estudadas);

b) "substituição": mostra a variação de participação de cada cultura dentro do sistema, podendo esse ser: negativo, quando no período analisado a cultura considerada foi 
substituída por outra(s) cultura(s) do sistema, ou seja, sua participação caiu; e positivo, quando ocorre o oposto, no período analisado a participação do produto eleva-se, indicando que a cultura estudada substituiu outra(s) dentro do sistema.

Assim, pode-se definir $\mathrm{AT}_{\mathrm{f}}$ o tamanho do sistema no período $\mathbf{f}$ e $\mathrm{AT}_{\mathrm{o}}$ tamanho do sistema no período 0 e $\lambda$ o coeficiente que mede a modificação do tamanho do sistema, já definido no item 3.2.2. A variação na área ocupada por uma cultura específica, em cada sistema de produção, é expressa por:

$$
\left(A T_{c f}-A T_{c 0}\right)
$$

podendo ser decomposta em dois efeitos, medidos em hectares:

$$
\begin{aligned}
& \left(\lambda A T_{c 0}-A T_{c 0}\right)=\text { Efeito escala (EE) } \\
& \left(A T_{c f}-\lambda A T_{c 0}\right)=\text { Efeito substituição (ES) }
\end{aligned}
$$

ou seja,

$$
\left(A T_{c f}-A T_{c 0}\right)=\left(\lambda A T_{c 0}-A T_{c 0}\right)+\left(A T_{c f}-\lambda A T_{c 0}\right)
$$

Dentro do sistema de produção somente se verifica a presença do efeito escala, pois a soma dos efeitos substituição é igual a zero, isto é,

$$
\sum_{c=1}^{n}\left(A_{c f}-\lambda A_{c 0}\right)=0
$$

Estes efeitos foram apresentados na forma de taxas anuais de crescimento, seguindo os mesmos procedimentos das transformações matemáticas apresentadas no item 3.2.3.1.1, ou seja, utilizando a expressão (13) e multiplicando-se ambos os lados da equação por

$$
\frac{1}{\left(A T_{c f}-A T_{c 0}\right)}
$$

tem-se

$$
1 \equiv \frac{\left(\lambda A T_{c 0}-A T_{c 0}\right)}{\left(A T_{c f}-A T_{c 0}\right)}+\frac{\left(A T_{c f}-\lambda A T_{c 0}\right)}{\left(A T_{c f}-A T_{c 0}\right)}
$$


Finalmente, multiplicando ambos os lados da identidade pelo efeito área (EA), definido anteriormente, tem-se

$$
E A=\frac{\left(\lambda A T_{c 0}-A T_{c 0}\right)}{\left(A T_{c f}-A T_{c 0}\right)} E A+\frac{\left(A T_{c f}-\lambda A T_{c 0}\right)}{\left(A T_{c f}-A T_{c 0}\right)} E A
$$

em que:

$$
\begin{aligned}
& \frac{\left(\lambda A T_{c 0}-A T_{c 0}\right)}{\left(A T_{c f}-A T_{c 0}\right)} E A=\text { efeito escala, expresso em \% ao ano; } \\
& \frac{\left(A T_{c f}-\lambda A T_{c 0}\right)}{\left(A T_{c f}-A T_{c 0}\right)} E A=\text { efeito substituição, expresso em \% ao ano. }
\end{aligned}
$$

Pressupondo que as culturas que cederam área o fizeram proporcionalmente para todas aquelas que expandiram suas áreas, pode-se determinar qual a parcela das áreas cedidas pelas culturas (efeito substituição negativo) que se destinou à produção das culturas que tiveram efeito substituição positivo. Tem-se assim,

$$
D_{c}=\frac{E S_{c}^{-}}{\sum_{c=1}^{n} E S_{c}^{-}}
$$

em que:

$\mathrm{D}_{\mathrm{c}}=$ parcela de perda da cultura $c$ em relação à perda total; $E S_{c}^{-}=$efeito substituição negativo da cultura c; $\sum_{c=1}^{n} E S_{c}^{-} \quad=$ somatório de todos os efeitos substituições negativos das culturas.

$\mathrm{O}$ ganho de área de uma cultura $c$ é

$$
G_{c}=\left(E S_{c}^{+}\right) D_{c}
$$

em que:

$G_{c} \quad=$ ganho de área da cultura $c$ que teve efeito substituição positivo; e $E S_{c}^{+}=$efeito substituição positivo de uma determinada cultura. 


\subsubsection{Análise do conjunto de culturas em cada microrregião}

Ao se estudar cada microrregião, o efeito localização torna-se nulo na análise de crescimento do valor da produção do conjunto das culturas, permanecendo apenas o efeito área, efeito rendimento e o efeito composição. Então, o valor da produção no período $\mathbf{f}$ para uma microrregião é dado por:

$$
V_{m f}=\sum_{c=1}^{n} A T_{c m f} R_{c m f} P_{c}=\sum_{c=1}^{n} \beta_{c m f} A T_{m f} R_{c m f} P_{c}
$$

e, no período 0 , tem-se:

$$
V_{m 0}=\sum_{c=1}^{n} A T_{c m 0} R_{c m 0} P_{c}=\sum_{c=1}^{n} \beta_{c m 0} A T_{m 0} R_{c m 0} P_{c}
$$

em que $\mathrm{V}_{\mathrm{m} 0}$ mede o valor da produção de uma microrregião no período 0 . Uma vez que se analisa um conjunto de culturas, a utilização da variável preço $\left(\mathrm{P}_{\mathrm{c}}\right)$ se faz necessária, como redutor a unidade comum. Essa variável é mantida fixa, já que pretendemos apenas analisar as modificações ocorridas na produção agrícola, não sendo possível medir a influência das mudanças dos preços relativos nas relações acima. Em toda análise será utilizado o preço do produto no período final (preço médio no triênio 1991-93).

Se do período 0 ao $\mathrm{f}$ alterar a área total cultivada na microrregião, permanecendo constante os rendimentos e a proporções das áreas das culturas $\left(\beta_{\mathrm{cm} 0}=\beta_{\mathrm{cmf}}\right)$, então o valor da produção no período $\mathbf{f}\left(V_{m f}^{A T}\right)$ será:

$$
V_{m f}^{A T}=\sum_{c=1}^{n} \beta_{c m 0} A T_{m f} R_{c m 0} P_{c}
$$

Modificando-se a área e o rendimento de cada cultura, permanecendo constantes as proporções das áreas, o valor da produção no período $\mathbf{f}\left(V_{m f}^{A T R}\right)$ será dado por:

$$
V_{m f}^{A T R}=\sum_{c=1}^{n} \beta_{c m 0} A T_{m f} R_{c m f} P_{c}
$$


E se também fossem alteradas as proporções das áreas das culturas, então ter-se-ia:

$$
V_{m f}^{A T R \beta}=\sum_{c=1}^{n} \beta_{c m f} A T_{m f} R_{c m f} P_{c}=V_{m f}
$$

A variação total no valor da produção de uma determinada microrregião, com preços constantes, pode ser expressa por:

$$
V_{m f}-V_{m 0}=\sum_{c=1}^{n} \beta_{c m f} A T_{m f} R_{c m f} P_{c}-\sum_{c=1}^{n} \beta_{c m 0} A T_{m 0} R_{c m 0} P_{c}
$$

ou

$$
V_{m f}-V_{m 0}=\left(V_{m f}^{A T}-V_{m 0}\right)+\left(V_{m f}^{A T R}-V_{m f}^{A}\right)+\left(V_{m f}-V_{m f}^{A T R}\right)
$$

em que:

$$
\begin{aligned}
V_{m f}-V_{m 0}= & \text { variação total no valor da produção da m-ésima microrregião, } \\
& \text { entre o período } 0 \text { e f; } \\
\left(V_{m f}^{A T}-V_{m 0}\right)= & \text { efeito área (EA); } \\
\left(V_{m f}^{A T R}-V_{m f}^{A T}\right)= & \text { efeito rendimento (ER); } \\
\left(V_{m f}-V_{m f}^{A T R}\right)= & \text { efeito composição do produto (ECP) }
\end{aligned}
$$

As transformações dos efeitos obtidos acima em taxas anuais de crescimento são feitas utilizando os mesmos procedimentos descritos no item 3.2.3.1.1.

\subsubsection{Análise do conjunto de culturas no Estado}

$\mathrm{Na}$ análise do crescimento da produção no Estado do Rio Grande do Norte serão levados em conta todos os efeitos: área, rendimento, localização geográfica e composição do produto. Será necessário utilizar preço dos produtos, como redutores a unidades comuns, já que se está analisando a produção agregada das diferentes culturas.

No período $\mathbf{f}$, o valor da produção estadual agregada $\left(V_{f}\right)$ é definida por: 


$$
V_{f}=\sum_{m=1}^{k} \sum_{c=1}^{n} \beta_{c m f} \alpha_{m f} A T_{f} R_{c m f} P_{c}
$$

Da mesma maneira, esse valor é calculado para o período inicial $\mathbf{0}$ :

$$
V_{0}=\sum_{m=1}^{k} \sum_{c=1}^{n} \beta_{c m 0} \alpha_{m 0} A T_{0} R_{c m 0} P_{c}
$$

Se no período estudado apenas se alterasse a área total cultivada, o valor da produção agregada estadual no período $\mathbf{f}\left(V_{f}^{A T}\right)$ seria:

$$
V_{f}^{A T}=\sum_{m=1}^{k} \sum_{c=1}^{n} \beta_{c m 0} \alpha_{m 0} A T_{f} R_{c m 0} P_{c}
$$

Com a área total cultivada e o rendimento das culturas em cada microrregião variando, o valor da produção no período $\mathbf{f}\left(V_{f}^{A T R}\right)$, é dado por:

$$
V_{f}^{A T R}=\sum_{m=1}^{k} \sum_{c=1}^{n} \beta_{c m 0} \alpha_{m 0} A T_{f} R_{c m f} P_{c}
$$

Mantendo-se fixa apenas a composição do produto em cada microrregião, ou seja, variando a área, rendimento e localização geográfica, o valor da produção $\left(V_{f}^{A T R \alpha}\right)$ seria:

$$
V_{f}^{A T R \alpha}=\sum_{m=1}^{k} \sum_{c=1}^{n} \beta_{c m 0} \alpha_{m f} A T_{f} R_{c m f} P_{c}
$$

Por último, quando também se altera a composição do produto tem-se que:

$$
V_{f}^{A T R \alpha \beta}=\sum_{m=1}^{k} \sum_{c=1}^{n} \beta_{c m f} \alpha_{m f} A T_{f} R_{c m f} P_{c}=V_{f}
$$

No período analisado de $\mathbf{0}$ a $\mathbf{f}$, a variação total no valor da produção agregada do Estado seria descrita da seguinte forma: 
$V_{f}-V_{0}=\sum_{m=1}^{k} \sum_{c=1}^{n} \beta_{c m f} \alpha_{m f} A T_{f} R_{c m f} P_{c}-\sum_{m=1}^{k} \sum_{c=1}^{n} \beta_{c m 0} \alpha_{m 0} A T_{0} R_{c m 0} P_{c}$

ou, podendo decompô-la isolando as causas de variação:

$$
V_{f}-V_{0}=\left(V_{f}^{A T}-V_{0}\right)+\left(V_{f}^{A T R}-V_{f}^{A T}\right)+\left(V_{f}^{A T R \alpha}-V_{f}^{A T R}\right)+\left(V_{f}-V_{f}^{A T R \alpha}\right)
$$

em que:

$V_{f}-V_{0} \quad=$ variação total observada no valor da produção estadual entre $\mathbf{0}$ e f;

$\left(V_{f}^{A T}-V_{0}\right) \quad=$ efeito área (EA);

$\left(V_{f}^{A T R}-V_{f}^{A T}\right)=$ efeito rendimento (ER);

$\left(V_{f}^{A T R \alpha}-V_{f}^{A T R}\right)=$ efeito localização geográfica (ELG)

$\left(V_{f}-V_{f}^{A T R \alpha}\right)=$ efeito composição do produto (ECP)

A transformação desses efeitos acima em taxas anuais de crescimento é feita de maneira semelhante à apresentada no item 3.2.3.1.1.

\subsection{Dados}

Os dados de área e produção utilizados no estudo foram obtidos dos Anuários Estatísticos do Rio Grande do Norte, publicados pela Fundação Instituto de Desenvolvimento do Rio Grande do Norte - FIDEC, os quais se encontram disponíveis, segundo microrregiões e municípios.

O período analisado (1980-93) correspondeu a 14 anos agrícolas. Os dados utilizados de área, produção e rendimento são médias trienais, centradas 1981, 1985, 1989 e 1992, de forma a evitar períodos de condições climáticas anormais, permitindo uma melhor identificação das variações ocorridas no período analisado. As culturas estudadas foram selecionadas a partir da análise da participação percentual dos 
produtos, tanto em relação à área total cultivada no Estado, como em relação ao valor da produção total. As culturas que apresentaram maior expressividade nos dois critérios foram selecionadas.

Os preços foram obtidos na Fundação Instituto Brasileiro de Geografia e Estatística - FIBGE e referem-se ao período de 1991 a 1993, deflacionados pelo Índice Geral de Preços-DI da Fundação Getúlio Vargas - FGV (base 1993=100). Nesse estudo foi utilizado o preço do produto no período final, isto é, o preço médio no triênio 199193 e esses foram mantidos fixos, pois o objetivo do trabalho é apenas analisar as modificações ocorridas na produção agrícola. 


\section{RESULTADOS E DISCUSSÕES}

Este capítulo está dividido em quatro seções. A primeira analisa a expansão e substituição de culturas; em seguida, a análise individual das culturas no Estado é apresentada; segue-se uma análise do crescimento da produção do conjunto das culturas em cada microrregião; por último, o estudo do crescimento da produção das culturas no Estado.

As culturas estudadas foram selecionadas através dos critérios de maior participação percentual em área cultivada e valor da produção, a saber: abacaxi, algodão arbóreo, algodão herbáceo, arroz, banana, batata-doce, caju, cana-de-açúcar, coco-dabaía, feijão, mandioca, manga, melão, milho, sisal e sorgo (apêndice 3, tabela 3.1 e tabela $3.2)$.

O milho, feijão, arroz, mandioca, batata-doce, caju, coco-da-baía, algodão arbóreo, algodão herbáceo, cana-de-açúcar e o sisal são culturas tradicionais na agricultura norte-riograndense. As cinco primeiras culturas são culturas de subsistência, exploradas na sua maioria por pequenos produtores, com um nivel tecnológico bastante tradicional. O algodão arbóreo e herbáceo, o sisal e a cana-de-açúcar são culturas de exportação e/ou industriais, exploradas por grandes produtores. Entre essas, a cultura canavieira é a que mais utiliza tecnologias (adubos, capinas, combate às pragas etc.).

O melão, manga e a banana são culturas mais recentes, estimuladas principalmente pela expansão da irrigação, e pelo seus altos valores comerciais. As duas primeiras são exploradas na sua maioria por grandes e médios produtores, enquanto a banana por pequenos. Todas utilizam tecnologias avançadas, com altos índices de produtividade.

As culturas do caju e do coco-da-baía são tradicionais, exploradas por grandes e médios produtores e apresentam baixos rendimentos. Na metade da década de 80 , o governo estadual passou a investir na recuperação dessas culturas e a estimular a 
produção. Já o abacaxi passou a ser plantado comercialmente no Rio Grande do Norte, com adoção de tecnologias mais avançadas pelos produtores rurais, quando a produção no Estado da Paraíba entrou em declínio.

\subsection{Expansão e substituição de culturas}

Para avaliar as alterações de área, calcularam-se o efeito escala e o efeito substituição derivados da avaliação da área total, em três subperíodos 1981/85, 1985/89 e 1989/92 e no período total 1981/92 (Tabelas 5 a 8). Sabemos que o efeito escala mede a alteração da área, isto é, resulta na ampliação ou redução do sistema de produção, e o efeito substituição expressa as alterações na área decorrentes de substituição havida entre as culturas. É importante lembrar que a estimativa do efeito substituição é feita na hipótese da proporcionalidade, isto é, supõe-se que as áreas são cedidas proporcionalmente a todas as culturas que expandiram suas áreas.

No período analisado neste trabalho (1981/92), o Rio Grande do Norte teve um efeito escala negativo na ordem da 228.695 ha (Tabela 5), significando uma retração absoluta das áreas das culturas, que podem ter sido ocupadas por pastagens nativas, reflorestamentos ou, simplesmente, ficando em pousio. Isso também ocorreu nos subperíodos de 1985/89 e 1989/92. A área ocupada com as principais culturas expandiu apenas no período de 1981-85.

No período de 1981/92, cinco culturas tiveram efeito substituição negativo, cedendo um total de 287.759 hectares, dos quais $65,8 \%$ provieram do algodão arbóreo, 26,4\% do algodão herbáceo e 7,8\% das demais culturas (sisal, batata-doce e arroz). Nota-se, também, que nesse período a área com essas culturas sofreu redução. Observa-se que do total cedido, $32,6 \%$ foram para o caju, $27,9 \%$ para o milho, $17,2 \%$ para o feijão, 8,8\% para a cana-de-açúcar, $8,2 \%$ para o coco-da-baía e $5,3 \%$ para as demais culturas (Tabela 5). Gasques e Verde (1990) encontraram resultados semelhantes para a região Nordeste, considerando dados dos anos agrícolas 1981/88.

No primeiro subperíodo (1981/85) foram cedidos 160.871 hectares, $75,1 \%$ pelo algodão arbóreo e algodão herbáceo, $11,5 \%$ pela mandioca e $13,3 \%$ pelas demais culturas que apresentaram o efeito substituição negativo (Tabela 6). Entre as 
principais culturas que tiveram ganhos substanciais nas suas áreas estão o milho e o feijão.

Tabela 5 - Decomposição do efeito área em efeitos escala e substituição, Rio Grande do Norte, no período de 1981 a 1992.

\begin{tabular}{|c|c|c|c|}
\hline \multirow{3}{*}{ Culturas } & \multicolumn{3}{|c|}{$1981-92$} \\
\hline & \multicolumn{3}{|c|}{ Efeitos (ha) } \\
\hline & Área & Escala & Substituição \\
\hline \multicolumn{4}{|l|}{ Efeito área positivo } \\
\hline Caju & $80.094,00$ & $-13.716,31$ & $93.810,31$ \\
\hline Milho & $67.839,67$ & $-12.426,07$ & $80.265,74$ \\
\hline Coco-da-baía & $19.262,67$ & $-4.373,73$ & $23.636,40$ \\
\hline Feijão "caupi" & $14.131,67$ & $-35.445,12$ & $49.576,78$ \\
\hline Cana-de-açúcar & $13.190,83$ & $-12.053,91$ & $25.244,74$ \\
\hline Sorgo & $2.611,17$ & $-1.192,91$ & $3.804,08$ \\
\hline Melão & $2.162,83$ & $-140,33$ & $2.303,16$ \\
\hline Abacaxi & $1.131,33$ & $-122,73$ & $1.254,06$ \\
\hline Manga & 254,00 & $-511,17$ & 765,17 \\
\hline Subtotal & $200.678,17$ & $-79.982,29$ & $280.660,45$ \\
\hline \multicolumn{4}{|c|}{ Efeito área negativo } \\
\hline Algodão Arbóreo & $-267.738,33$ & $-78.534,36$ & $-189.203,98$ \\
\hline Algodão herbáceo & $-115.836,33$ & $-39.919,25$ & $-75.917,08$ \\
\hline Sisal & $-30.494,00$ & $-9.853,37$ & $-20.640,63$ \\
\hline Mandioca & $-9.800,67$ & $-16.211,42$ & $6.410,75$ \\
\hline Batata doce & $-3.677,83$ & $-2.051,98$ & $-1.625,86$ \\
\hline Arroz & $-1.611,67$ & $-1.240,18$ & $-371,49$ \\
\hline Banana & $-215,00$ & $-902,83$ & 687,83 \\
\hline Subtotal & $-429.373,83$ & $-148.713,38$ & $-280.660,45$ \\
\hline TOTAL & $-228.695,67$ & $-228.695,67$ & 0,00 \\
\hline
\end{tabular}

Fonte: Dados básicos do Anuário Estatístico do Rio Grande do Norte - FIDEC. 
Tabela 6 - Decomposição do efeito área em efeitos escala e substituição, Rio Grande do Norte, no subperíodo de 1981 a 1985.

\begin{tabular}{l|r|r|r}
\hline \multirow{2}{*}{ Culturas } & \multicolumn{3}{c}{$1981-85$} \\
\cline { 2 - 4 } & \multicolumn{3}{c}{ Efeitos (ha) } \\
\cline { 2 - 4 } & \multicolumn{1}{c}{ Área } & \multicolumn{1}{c}{ Escala } & \multicolumn{1}{c}{ Substituição } \\
\hline Efeito área positivo & \multicolumn{3}{c}{} \\
Milho & $115.261,33$ & $12.654,71$ & $102.606,63$ \\
Feijão "caupi” & $85.949,67$ & $36.097,28$ & $49.852,38$ \\
Cana-de-açúcar & $12.127,67$ & $12.275,69$ & $-148,02$ \\
Algodão. Arbóreo & $8.118,67$ & $79.979,33$ & $-71.860,67$ \\
Sorgo & $7.360,83$ & $1.214,86$ & $6.145,98$ \\
Caju & $7.218,00$ & $13.968,68$ & $-6.750,68$ \\
Coco-da-baía & $4.412,33$ & $4.454,21$ & $-41,87$ \\
Arroz & $3.497,67$ & $1.262,99$ & $2.234,67$ \\
Sisal & 480,67 & $10.034,66$ & $-9.554,00$ \\
Abacaxi & 157,00 & 124,99 & 32,01 \\
Melão & 34,00 & 142,91 & $-108,91$ \\
Subtotal & $244.617,83$ & $172.210,31$ & $72.407,52$
\end{tabular}

Efeito área negativo

\begin{tabular}{lrrr} 
Algodão. herbáceo & $-8.419,00$ & $40.653,74$ & $-49.072,74$ \\
Mandioca & $-1.956,00$ & $16.509,70$ & $-18.465,70$ \\
Batata doce & $-765,67$ & $2.089,73$ & $-2.855,40$ \\
Banana & $-484,33$ & 919,44 & $-1.403,78$ \\
Manga & $-89,33$ & 520,58 & $-609,91$ \\
Subtotal & $-11.714,33$ & $60.693,19$ & $-72.407,52$ \\
\hline TOTAL & $232.903,50$ & $232.903,50$ & 0,00
\end{tabular}

Fonte: Dados básicos do Anuário Estatístico do Rio Grande do Norte - FIDEC. 
Tabela 7 - Decomposição do efeito área em efeitos escala e substituição, Rio Grande do Norte, no subperíodo de 1985 a 1989.

\begin{tabular}{l|r|r|r}
\hline \multirow{2}{*}{ Culturas } & \multicolumn{3}{|c}{$1985-89$} \\
\cline { 2 - 4 } & \multicolumn{3}{|c}{ Efeitos (ha) } \\
\cline { 2 - 4 } & \multicolumn{1}{c|}{ Área } & \multicolumn{1}{c}{ Escala } & \multicolumn{1}{c}{ Substituição } \\
\hline Efeito área positivo & $36.104,67$ & $-19.529,98$ & $55.634,65$ \\
Caju & $7.171,33$ & $-6.969,82$ & $14.141,15$ \\
Coco-da-baía & $3.846,00$ & $-19.197,18$ & $23.043,18$ \\
Cana-de-açúcar & $1.527,67$ & $-207,25$ & $1.734,92$ \\
Abacaxi & 637,00 & $-948,10$ & $1.585,10$ \\
Banana & 623,33 & $-185,80$ & 809,13 \\
Melão & 19,67 & $-601,82$ & 621,49 \\
Manga & $49.929,67$ & $-47.639,95$ & $97.569,61$ \\
Subtotal & &
\end{tabular}

\section{Efeito área negativo}

\begin{tabular}{lrrr} 
Algodão Arbóreo & $-190.159,33$ & $-100.142,75$ & $-90.016,58$ \\
Algodão herbáceo & $-98.321,50$ & $-46.490,93$ & $-51.830,57$ \\
Feijão "caupi" & $-53.345,83$ & $-74.134,82$ & $20.788,99$ \\
Milho & $-36.910,50$ & $-55.926,99$ & $19.016,49$ \\
Sisal & $-26.932,67$ & $-12.375,30$ & $-14.557,37$ \\
Arroz & $-3.621,50$ & $-2.766,33$ & $-855,17$ \\
Mandioca & $-2.623,00$ & $-19.394,70$ & $16.771,70$ \\
Sorgo & $-1.642,83$ & $-4.066,33$ & $2.423,50$ \\
Batata doce & $-1.583,33$ & $-2.272,71$ & 689,38 \\
Subtotal & $-415.140,50$ & $-317.570,89$ & $-97.569,61$ \\
\hline TOTAL & $-365.210,83$ & $-365.210,83$ & 0,00 \\
\hline
\end{tabular}

Fonte: Dados básicos do Anuário Estatístico do Rio Grande do Norte - FIDEC. 
Tabela 8 - Decomposição do efeito área em efeitos escala e substituição, Rio Grande do Norte, no subperiodo de 1989 a 1992.

\begin{tabular}{l|c|c|c}
\hline \multirow{2}{*}{ Culturas } & \multicolumn{3}{|c}{$1989-92$} \\
\cline { 2 - 4 } & \multicolumn{3}{|c}{ Efeitos (ha) } \\
\cline { 2 - 4 } & Área & Escala & Substituição \\
\hline
\end{tabular}

\section{Efeito área positivo}

Caju

Coco-da-baía

Melão

Manga

Subtotal

\section{Efeito área negativo}

Algodão. Arbóreo

Feijão "caupi"

Milho

Algodão. herbáceo

Mandioca

Sisal

Sorgo

Cana-de-açúcar

Arroz

Batata doce

Banana

Abacaxi

Subtotal

TOTAL
$36.771,33$

$7.679,00$

$1.505,50$

323,67

$46.279,50$

$-85.697,67$

$-18.472,17$

$-10.511,17$

$-9.095,83$

$-5.221,67$

$-4.042,00$

$-3.106,83$

$-2.782,83$

$-1.487,83$

$-1.328,83$

$-367,67$

$-553,33$

$-142.667,83$

$-96.388,33$
$-13.119,00$

$-3.863,93$

$-164,87$

$-247,81$

$-17.395,60$
$63.675,10$

$49.890,33$

$11.542,93$

$1.670,37$

571,47

Fonte: Dados básicos do Anuário Estatístico do Rio Grande do Norte - FIDEC. 
Entre 1985 e 1989, as mudanças tiveram praticamente o mesmo comportamento do período anterior, pois dos 157.259 hectares cedidos, $90 \%$ provieram do algodão arbóreo e herbáceo, $9,3 \%$ do sisal e $0,5 \%$ do arroz, sendo incorporados principalmente pelo caju $(35,4 \%)$, cana-de-açúcar $(14,7 \%)$, feijão $(13,2 \%)$, milho $(12,1 \%)$ e mandioca $(10,7 \%)$ (Tabela 7$)$.

Como pode ser verificado na Tabela 8, no subperíodo de 1989/92 caiu pela metade a quantidade de hectares cedidos ( 82.707 hectares), nos quais as maiores percentagens das áreas cedidas continuaram sendo do algodão arbóreo $(87,2 \%)$ e do algodão herbáceo $(5,1 \%)$ e $7,7 \%$ das demais culturas (sisal, sorgo, arroz, batata-doce e abacaxi). Essas áreas destinaram-se na maior parte para o caju $(60,3 \%)$, coco-da-baía (14\%), milho $(8,4 \%)$ e cana-de-açúcar $(6,7 \%)$.

Esses resultados de incorporação de área, entretanto, devem ser considerados com uma certa reserva, já que o presente estudo não levou em consideração todas as culturas plantadas no Estado e também não foram incluídas as áreas com pastagens, devido à ausência de dados estatísticos para as respectivas microrregiões e para o Estado. A exclusão dessas áreas podem introduzir algumas distorções nos resultados das culturas que incorporaram áreas, tanto devido ao modelo não ser capaz de fazer inferências sobre áreas que não estejam dentro sistema de produção analisado, como também devido à adoção da hipótese de proporcionalidade na estimativa do efeito substituição.

Em uma entrevista informal com pesquisadores da Empresa de Pesquisa Agropecuária do Rio Grande do Norte - EMPARN, estes afirmaram que a incorporação da área cedida no semi-árido norte-riograndense pelo algodão arbóreo foi feita principalmente pela pecuária e por algumas culturas de subsistência, o restante ficando em pousio. Se isso realmente ocorreu, o modelo não conseguiu captar.

Em todos os períodos analisados, observou-se que atividades agrícolas de grande expressão estadual, em termos de área ocupada, como algodão arbóreo e algodão herbáceo, estão entre aquelas que mais cederam áreas. Por outro lado, as culturas do caju, milho, coco-da-baía, feijão e cana-de-açúcar foram as que mais expandiram suas 
áreas devido à incorporação das áreas cedidas, já que o efeito escala se apresentou negativo.

As áreas do caju, coco-da-baía e melão cresceram em todos os subperíodos analisados. A expansão dessas culturas se fizeram presentes, com maior intensidade, a partir do segundo subperíodo, ao contrário do que ocorreu com o algodão herbáceo, mandioca e batata-doce que tiveram comportamento declinante em todos os subperíodos.

Um outro aspecto importante foi a sensível diminuição na área ocupada com as culturas incluídas nesta pesquisa. Os 805 mil hectares plantados em 1981, passaram para 576 mil hectares em 1992, sofrendo assim, um decréscimo de 28,38\%. Apenas no primeiro subperíodo (1981-1985) é que se verificou um aumento de $28,8 \%$ na área do sistema de produção estudado, isto é, de 805.608 para 1.038 .551 hectares. Nos subperíodos subseqüentes ocorreram decréscimos nas áreas plantadas, de 35,2\% entre 1985 e 1989 (de 1.038 .511 para 673 mil hectares) e de 14,3\% no subperíodo de 1989 a 1992 (de 673 para 576 mil hectares).

Em suma, das culturas com efeito área positivo somente duas pertencem ao grupo de culturas tradicionais de subsistência: o milho e o feijão. O caju, com maior crescimento no período, e o coco-da-baía, na terceira colocação de crescimento de área, são culturas tradicionais, porém beneficiadas por políticas de estímulo à produção.

Das culturas tradicionais de exportação, cultivadas por grandes produtores, somente a cana-de-açúcar apresentou expansão na área cultivada (o quinto maior efeito área). As outras culturas que tiveram suas área expandidas no período, principalmente depois de 1985, são culturas não-tradicionais, geralmente irrigadas, a saber: melão, manga, e sorgo encontradas em grandes e médias propriedades, e o abacaxi cultivado por pequenos produtores.

\subsection{Análise por cultura no Estado}

Os componentes da taxa média anual de variação da produção, obtidos através da utilização do modelo "shift-share" da análise individual das culturas no Estado, encontram-se nas tabelas 9 a 12 . 
Tabela 9 - Taxa média anual de crescimento das culturas, decomposta em efeitos área, rendimento e localização geográfica, Rio Grande do Norte, 1981-92.

\begin{tabular}{|c|c|c|c|c|c|c|}
\hline \multirow{4}{*}{ Culturas } & \multirow{4}{*}{$\begin{array}{l}\text { Taxa anual de } \\
\text { crescimento da } \\
\text { produção (\%) }\end{array}$} & \multicolumn{5}{|c|}{$1981-92$} \\
\hline & & \multicolumn{5}{|c|}{ Fontes de crescimento (\%) } \\
\hline & & \multicolumn{3}{|c|}{ Efeito área } & \multirow{2}{*}{$\begin{array}{c}\text { Efeito } \\
\text { Rendimento }\end{array}$} & \multirow{2}{*}{$\begin{array}{c}\text { Efeito } \\
\text { Localização }\end{array}$} \\
\hline & & Total & Escala & Substituição & & \\
\hline Milho & 24,14 & 3,82 & $-0,7$ & 4,52 & 19,79 & 0,53 \\
\hline Melão & 16,61 & 16,44 & $-1,07$ & 17,51 & $-0,99$ & 1,16 \\
\hline Caju & 14,74 & 6,91 & $-1,18$ & 8,09 & 9,49 & $-1,66$ \\
\hline Abacaxi & 13,03 & 11,97 & $-1,3$ & 13,27 & 1,33 & $-0,27$ \\
\hline Feijão "caupi" & 12,1 & 0,54 & $-1,37$ & 1,91 & 10,47 & 1,09 \\
\hline Sorgo & 11,56 & 3,08 & $-1,41$ & 4,49 & 8,78 & $-0,3$ \\
\hline Arroz & 7,46 & $-2,28$ & $-1,76$ & $-0,53$ & 9,01 & 0,73 \\
\hline Coco-da-baía & 5,99 & 8,36 & $-1,9$ & 10,26 & $-3,12$ & 0,75 \\
\hline Cana-de-açúcar & 1,23 & 2,65 & $-2,43$ & 5,08 & $-1,6$ & 0,18 \\
\hline Manga & 0,03 & 1,28 & $-2,58$ & 3,86 & $-0,78$ & $-0,47$ \\
\hline Banana & $-1,87$ & $-0,67$ & $-2,83$ & 2,16 & $-1,21$ & 0,01 \\
\hline Mandioca & $-2,91$ & $-1,80$ & $-2,98$ & 1,18 & $-1,04$ & $-0,07$ \\
\hline Alg. herbáceo & $-6,29$ & $-10,15$ & $-3,5$ & $-6,65$ & 3,89 & $-0,03$ \\
\hline Batata doce & $-7,17$ & $-6,53$ & $-3,64$ & $-2,89$ & $-0,48$ & $-0,16$ \\
\hline Sisal & $-11,93$ & $-13,92$ & $-4,5$ & $-9,42$ & 1,62 & 0,37 \\
\hline Alg. Arbóreo & $-22,18$ & $-22,92$ & $-6,72$ & $-16,20$ & 0,56 & 0,18 \\
\hline
\end{tabular}

Fonte: Dados básicos do Anuário Estatístico do Rio Grande do Norte - FIDEC. 
Tabela 10 - Taxa média anual de crescimento das culturas, decomposta em efeitos área, rendimento e localização geográfica, Rio Grande do Norte, 1981-85.

\begin{tabular}{|c|c|c|c|c|c|c|}
\hline \multirow{4}{*}{ Culturas } & \multicolumn{6}{|c|}{$1981-85$} \\
\hline & \multirow{3}{*}{$\begin{array}{l}\text { Taxa anual de } \\
\text { crescimento da } \\
\text { produção (\%) }\end{array}$} & \multicolumn{5}{|c|}{ Fontes de crescimento $(\%)$} \\
\hline & & \multicolumn{3}{|c|}{ Efeito área } & \multirow{2}{*}{$\begin{array}{c}\text { Efeito } \\
\text { Rendimento }\end{array}$} & \multirow{2}{*}{$\begin{array}{c}\text { Efeito } \\
\text { Localização }\end{array}$} \\
\hline & & Total & Escala & Substituição & & \\
\hline Milho & 109,05 & 15,87 & 1,74 & 14,12 & 104,31 & $-11,13$ \\
\hline Sorgo & 59,29 & 19,10 & 3,15 & 15,95 & 39,50 & 0,69 \\
\hline Arroz & 58,99 & 8,76 & 3,16 & 5,60 & 52,74 & $-2,51$ \\
\hline Feijão "caupi" & 54,85 & 7,95 & 3,34 & 4,61 & 50,59 & $-3,69$ \\
\hline Alg. herbáceo & 13,56 & $-1,22$ & 5,91 & $-7,14$ & 16,09 & $-1,31$ \\
\hline Abacaxi & 9,10 & 7,93 & 6,31 & 1,62 & 1,18 & $-0,01$ \\
\hline Coco-da-baía & 7,18 & 6,43 & 6,49 & $-0,06$ & 1,28 & $-0,53$ \\
\hline Cana-de-açúcar & 6,92 & 6,44 & 6,52 & $-0,08$ & 0,32 & 0,16 \\
\hline Sisal & 5,22 & 0,32 & 6,69 & $-6,37$ & 4,90 & 0,00 \\
\hline Alg. Arbóreo & 4,69 & 0,68 & 6,74 & $-6,05$ & 5,18 & $-1,17$ \\
\hline Mandioca & 0,73 & $-0,85$ & 7,15 & $-8,00$ & 1,28 & 0,30 \\
\hline Manga & $-0,85$ & $-1,26$ & 7,32 & $-8,58$ & 0,43 & $-0,02$ \\
\hline Banana & $-1,55$ & $-3,90$ & 7,40 & $-11,29$ & 2,04 & 0,31 \\
\hline Caju & $-2,16$ & 3,86 & 7,47 & $-3,61$ & $-6,38$ & 0,36 \\
\hline Batata doce & $-2,00$ & $-2,73$ & 7,45 & $-10,18$ & 1,28 & $-0,55$ \\
\hline Melão & $-7,69$ & 1,93 & 8,12 & $-6,19$ & $-8,81$ & $-0,81$ \\
\hline
\end{tabular}

Fonte: Dados básicos do Anuário Estatístico do Rio Grande do Norte - FIDEC. 
Tabela 11 - Taxa média anual de crescimento das culturas, decomposta em efeitos área, rendimento e localização geográfica, Rio Grande do Norte, 1985-89.

\begin{tabular}{|c|c|c|c|c|c|c|}
\hline \multirow{4}{*}{ Culturas } & \multicolumn{6}{|c|}{$1985-89$} \\
\hline & \multirow{3}{*}{$\begin{array}{l}\text { Taxa anual de } \\
\text { crescimento da } \\
\text { produção (\%) }\end{array}$} & \multicolumn{5}{|c|}{ Fontes de crescimento $(\%)$} \\
\hline & & \multicolumn{3}{|c|}{ Efeito área } & \multirow{2}{*}{$\begin{array}{c}\text { Efeito } \\
\text { Rendimento }\end{array}$} & \multirow{2}{*}{$\begin{array}{c}\text { Efeito } \\
\text { Localização }\end{array}$} \\
\hline & & Total & Escala & Substituiçào & & \\
\hline$\overline{\text { Caju }}$ & 55,09 & 7,48 & $-4,05$ & 11,53 & 51,27 & $-3,66$ \\
\hline Abacaxi & 43,19 & 34,95 & $-4,74$ & 39,69 & 9,42 & $-1,18$ \\
\hline Melão & 35,85 & 17,58 & $-5,24$ & 22,82 & 13,02 & 5,25 \\
\hline Sorgo & 1,46 & $-3,47$ & $-8,60$ & 5,13 & 5,48 & $-0,55$ \\
\hline Manga & 0,60 & 0,28 & $-8,71$ & 9,00 & 1,64 & $-1,32$ \\
\hline Cana-de-açúcar & 0,50 & 1,75 & $-8,73$ & 10,47 & $-1,46$ & 0,21 \\
\hline Banana & 0,21 & 5,89 & $-8,76$ & 14,65 & $-5,72$ & 0,04 \\
\hline Coco-da-baía & $-0,22$ & 9,08 & $-8,82$ & 17,90 & $-8,74$ & $-0,56$ \\
\hline Mandioca & $-3,17$ & $-1,25$ & $-9,22$ & 7,97 & $-1,84$ & $-0,08$ \\
\hline Batata doce & $-8,55$ & $-6,97$ & $-10,00$ & 3,03 & $-1,42$ & $-0,16$ \\
\hline Feijão "caupi" & $-9,78$ & $-7,33$ & $-10,19$ & 2,86 & $-2,33$ & $-0,12$ \\
\hline Milho & $-10,34$ & $-6,78$ & $-10,28$ & 3,50 & $-3,63$ & 0,07 \\
\hline Arroz & $-12,07$ & $-13,82$ & $-10,55$ & $-3,26$ & 0,33 & 1,42 \\
\hline Sisal & $-17,38$ & $-24,91$ & $-11,44$ & $-13,46$ & 5,77 & 1,76 \\
\hline Alg. Arbóreo & $-22,21$ & $-23,40$ & $-12,32$ & $-11,08$ & 0,54 & 0,65 \\
\hline Alg. herbáceo & $-23,88$ & $-26,74$ & $-12,64$ & $-14,09$ & 1,72 & 1,14 \\
\hline
\end{tabular}

Fonte: Dados básicos do Anuário Estatístico do Rio Grande do Norte - FIDEC. 
Tabela 12 - Taxa média anual de crescimento das culturas, decomposta em efeitos área, rendimento e localização geográfica, Rio Grande do Norte, 1989-92.

\begin{tabular}{l|c|c|c|c|c|c}
\hline \multirow{2}{*}{ Culturas } & \multicolumn{5}{|c}{$1989-92$} \\
\cline { 2 - 5 } & Taxa anual de & \multicolumn{5}{|c}{ Fontes de crescimento (\%) } \\
\cline { 3 - 6 } & crescimento da & \multicolumn{3}{|c}{ Efeito área } & Efeito & Efeito \\
\cline { 3 - 6 } & produção (\%) & Total & Escala & Substituição & Rendimento & Localização \\
\hline Melão & 29,88 & 32,79 & $-3,59$ & 36,39 & $-5,23$ & 2,32 \\
Coco-da-baia & 13,15 & 8,34 & $-4,2$ & 12,54 & 4,41 & 0,4 \\
Manga & 0,45 & 6,21 & $-4,75$ & 10,96 & $-5,53$ & $-0,23$ \\
Feijão "caupi" & $-2,67$ & $-4,02$ & $-4,9$ & 0,88 & 1,20 & 0,15 \\
Alg. herbáceo & $-4,31$ & $-9,35$ & $-4,98$ & $-4,36$ & 4,58 & 0,46 \\
Milho & $-4,37$ & $-3,00$ & $-4,99$ & 1,99 & $-1,6$ & 0,23 \\
Banana & $-4,99$ & $-3,87$ & $-5,02$ & 1,15 & $-0,84$ & $-0,28$ \\
Cana-de-açúcar & $-4,98$ & $-1,67$ & $-5,02$ & 3,35 & $-3,35$ & 0,04 \\
Caju & $-5,08$ & 14,08 & $-5,02$ & 19,1 & $-17,82$ & $-1,34$ \\
Mandioca & $-7,26$ & $-3,57$ & $-5,14$ & 1,57 & $-3,6$ & $-0,09$ \\
Abacaxi & $-13,54$ & $-10,01$ & $-5,48$ & $-4,53$ & $-3,44$ & $-0,09$ \\
Batata doce & $-11,9$ & $-10,25$ & $-5,39$ & $-4,86$ & $-1,6$ & $-0,05$ \\
Arroz & $-16,72$ & $-13,87$ & $-5,67$ & $-8,21$ & $-5,39$ & 2,54 \\
Sorgo & $-21,25$ & $-13,01$ & $-5,95$ & $-7,06$ & $-7,19$ & $-1,05$ \\
Sisal & $-24,33$ & $-21,01$ & $-6,15$ & $-14,87$ & $-3,11$ & $-0,21$ \\
Alg. Arbóreo & $-47,59$ & $-50,36$ & $-7,96$ & $-42,40$ & 2,69 & 0,08 \\
\hline
\end{tabular}

Fonte: Dados básicos do Anuário Estatístico do Rio Grande do Norte - FIDEC.

As culturas que apresentaram efeito área positivo no período de 1981 a 1992 foram também as que apresentaram as maiores taxas de crescimento anual da produção. O milho $(24,14 \%)$, o melão $(16,61 \%)$, o caju $(14,74 \%)$, o abacaxi $(13,03 \%)$, o feijão $(12,1 \%)$ e o sorgo (11,56\%) são as de crescimento mais rápido (Tabela 9). Com um crescimento mais moderado seguem-se o arroz $(7,46 \%)$, o coco-da-baía $(5,99 \%)$ e a cana-de-açúcar $(1,23 \%)$. A taxa de crescimento da produção de manga foi praticamente nula para o período analisado. Os principais efeitos explicativos do comportamento 
dessas culturas alternaram principalmente entre o efeito rendimento e o efeito área. $\mathrm{O}$ efeito localização geográfica foi positivo praticamente para todas as culturas, indicando que a proporção da área total cultivada no Estado por cada cultura cresceu nas regiões que apresentam maiores indices de produtividade.

Apesar das altas taxas de crescimento da produção, verifica-se uma certa variação em relação à área plantada daquelas culturas. Dos 576.912 hectares plantados no Rio Grande do Norte em 1992, essas culturas participavam com $83,7 \%$, sendo 138.991 hectares plantados com feijão, 128.411 hectares com caju, 111.612 hectares com milho, 55.652 hectares com cana-de-açúcar e 34.670 hectares com coco-da-baía. Por outro lado, a área plantada com arroz, melão, abacaxi e sorgo não ultrapassavam 14.000 hectares. É interessante notar, no entanto, que apesar das diferenças em área plantada, o valor percentual da produção dessas culturas são próximos (Tabela 3.2., apêndice 3).

No mesmo período, apresentaram declínio na produção as culturas do algodão arbóreo $(-22,18 \%)$, sisal $(-11,93 \%)$, batata-doce $(-7,17 \%)$, algodão herbáceo $(-6,29 \%)$, mandioca $(-2,92 \%)$ e a banana $(-1,87 \%)$. A retração da área foi a principal fonte explicativa dessa taxa de crescimento negativa da produção.

O comportamento das taxas de crescimento das culturas oscilou entre os subperiodos analisados. De 1981 a 1985, praticamente todas as culturas tiveram taxas de crescimento positivas. O sorgo, o abacaxi e a cana-de-açúcar foram as culturas que permaneceram com taxas positivas de crescimento no subperiodo seguinte (1985-89). Entre os subperiodos 1985-89 e 1989-92, com exceção do melão, do coco-da-baía e da manga, todas as outras culturas começaram apresentar uma tendência decrescente, como foi o caso do algodão arbóreo, arroz, sisal, batata-doce e da mandioca que continuaram com taxas de crescimento negativas e declinantes, e do sorgo, abacaxi, caju, cana-deaçúcar e banana que passaram a exibir taxas negativas de crescimento da produção.

Percebe-se que essas oscilações na produção das culturas norteriograndenses estão bastante relacionadas às irregularidades climáticas. Ao comparar a precipitação média anual com a precipitação histórica estadual, constata-se que o início dos anos 80 e 90 variaram de seco a extremamente seco, ou seja, a média das precipitações anuais ficou muito abaixo da média histórica. As precipitações médias 
nesses períodos variaram de 251 a $621 \mathrm{~mm}$ anuais, provavelmente influenciando na redução da área plantada, como se verificou, ao comparar o período de 1989 com o de 1992 , onde muitas culturas tiveram crescimento negativo, explicado na sua maioria pela retração de área. Os anos de 1984, 1985 e 1986 foram considerados chuvosos, podendo também, em parte, justificar a taxa de crescimento positiva da maior parte das culturas entre 1981 e 1985. Uma justificativa parecida pode ser dada às oscilações da produção ocorridas entre 1985 e 1989, já que os anos de 1987 a 1989 foram bastante instáveis quanto às chuvas.

\section{Milho}

Entre todas as culturas analisadas, o milho foi que obteve a maior taxa média anual de crescimento da produção $(24,14 \%)$ no periodo de 1981-1992 (Tabela 9) Esta alta taxa de crescimento da produção é explicada, em sua maior parte, através do aumento de produtividade ( $\mathrm{ER}=19,79 \%$ ao ano). O efeito área apresentou apreciável magnitude de $3,82 \%$ ao ano e o efeito localização geográfica foi de $0,53 \%$ ao ano. $O$ subperíodo de 1981-85 foi responsável por esse aumento, uma vez que essa cultura sofreu queda na produção nos subperiodos subseqüentes (Tabelas 10,11 e 12).

O maior dinamismo no crescimento da produção de milho se observa entre 1981 e 1985, com sua produção acrescida a uma taxa anual de 109,05\%, explicada basicamente pelo efeito rendimento de $104,31 \%$ ao ano. O efeito área foi de $15,87 \%$ ao ano, e o efeito localização negativo, de $-11,13 \%$ ao ano, indicando a crescente participação relativa da cultura em regiões de menor produtividade. Esse aumento na produtividade e na área pode estar relacionado pela regularidade climática do período.

A maior queda na produção foi detectada no segundo subperíodo (198589), com uma taxa de variação da produção de $-10,34 \%$ ao ano. Isso se explica pela redução de área $(E A=-6,78 \%$ ao ano) e pela queda da produtividade $(E R=-3,63 \%$ ao ano). O mesmo comportamento ocorreu no período seguinte (1989-92), no qual obteve uma taxa média anual de decréscimo da produção de $-4,37 \%$, sendo que os efeitos área e rendimento participaram com $-3 \%$ e $-1,6 \%$ ao ano, respectivamente. 
O milho foi a sexta atividade norte-riograndense em área plantada em 1981 com 5,4\% da superficie agricola (43.772 ha), e numa alternância de aumentos $\mathrm{e}$ diminuições alcançou 19,3\% em 1992, correspondendo a uma área de 111 mil hectares, passando assim a ocupar a terceira colocação em área plantada, atrás apenas do feijão e do caju. É plantada em todas as microrregiões do Estado, principalmente nas regiões Serrana Norte-riograndense, Agreste Potiguar, Borborema Potiguar e Seridó, sendo responsáveis por $66 \%$ da área plantada e $74 \%$ da produção estadual. A região de AçuApodi, que ocupava o terceiro lugar em área plantada em 1981, passou para o sétimo em 1992, ocorrendo o inverso com a microrregião da Borborema Potiguar.

O milho é cultivado tanto em áreas irrigadas com a cultivar BR 106, como em áreas de sequeiro, com BR 5028 (São Francisco), BR 5037 (Cruzeta) e outras variedades. Usando as tecnologias recomendadas, os produtores conseguem uma média de $2.500 \mathrm{~kg} / \mathrm{ha}$. Apesar de todas as pesquisas e do trabalho de extensão, o sistema de produção em uso é muito deficiente e a produtividade baixa $(440 \mathrm{~kg} / \mathrm{ha})$, muito aquém da média nacional.

\section{Melão}

No período de 1981 a 1992, o melão apresentou a segunda maior taxa de crescimento anual da produção entre as culturas estudadas, ficando em torno de $16,61 \%$ ao ano (Tabela 9), explicada principalmente pelo efeito área de $16,44 \%$ ao ano e em menor proporção pelo efeito localização geográfica de $1,16 \%$ ao ano, mostrando que essa cultura cresceu mais em regiões de produtividade mais elevada. $\mathrm{Na}$ decomposição do efeito área, o efeito substituição de $17,51 \%$ ao ano contribuiu de modo decisivo para a expansão da área, superando o efeito escala de $-1,07 \%$ ao ano.

Essa cultura apresentou um decréscimo na produção apenas no primeiro subperíodo (1981-85), com taxa média anual de $-7,69 \%$ (Tabela 10). Essa taxa negativa deve-se quase que na sua totalidade ao efeito rendimento de $-8,81 \%$ ao ano e ao efeito localização geográfica de $-0,81 \%$ ao ano, apesar da expansão da área plantada ocorrida nesse periodo $(\mathrm{EA}=1,93 \%$ ao ano). 
No segundo subperíodo (1985-1989) verifica-se um elevado crescimento da produção, com uma expressiva taxa média anual de $35,85 \%$ (Tabela 11), a qual teve reflexo positivo sobre o periodo de 1981-1992. Os efeitos explicativos (área, rendimento e localização geográfica) foram, respectivamente, de $17,58 \%, 13,02 \%$ e 5,25\% ao ano.

No subperíodo de 1989-92, a produção continuou a crescer com uma taxa de $29,88 \%$ ao ano, devido principalmente à expansão de área ( $\mathrm{EA}=32,79 \%$ ao ano). Esse último efeito, quando decomposto nos efeitos escala e substituição, mostra que o melão substituiu áreas de outras culturas no período considerado, uma vez que o efeito substituição foi de $36,39 \%$ ao ano. Os efeitos localização geográfica e rendimento participaram com $2,32 \%$ e $-5,23 \%$ ao ano, respectivamente.

Essa cultura é recente, plantada principalmente em perímetros irrigados. Apesar da pequena área plantada, cerca de 2.600 ha, o melão continua aumentando sua participação na composição da produção. A microrregião Salineira Norte-riograndense era e continua sendo a principal produtora, respondendo em 1992 por $75,9 \%$ da área plantada no Estado, seguida pela região de Açu-Apodi $(20,7 \%)$. A ampliação da área vem sendo feita por grandes produtores com a incorporação de tecnologia mais avançada, o que permite a obtenção de elevados niveis de produtividade, cerca de 14 mil frutos/ha. O Rio Grande do Norte é responsável por $60 \%$ do consumo interno do melão nacional e ainda participa com $40 \%$ das exportações.

\section{Caju}

A cultura do caju ocupou o segundo lugar em área plantada $(22,2 \%)$ no Rio Grande do Norte em 1992, isto é, 128 mil hectares. No decorrer do período analisado, o cultivo do caju aumentou sua participação relativa, em termos de área plantada e produção, nas microrregiões Salineira Norte-riograndense, Açu-Apodi, Natal, Litoral de São Bento Norte e Serra Verde, as quais respondem por $87 \%$ da área plantada e $83 \%$ da produção do Estado. Dessas regiões, a Salineira Norte-riograndense, AçuApodi e Natal continuam ocupando as primeiras posições em área plantada. Em 1981 praticamente não existia plantação de caju nas regiões do Litoral de São Bento Norte e 
Serra Verde, que passaram a responder em 1992 por $11,7 \%$ e $9,3 \%$ da área plantada no Estado, respectivamente.

Como pode ser verificado na Tabela 9, no periodo 1981-92, a taxa média anual de crescimento da quantidade produzida foi de 14,74\%, destacando-se como componentes explicativos o efeito rendimento com $9,49 \%$ ao ano e o efeito área de $6,91 \%$ ao ano. Esse efeito área é explicado principalmente pelo efeito substituição $(8,09 \%$ ao ano). O efeito escala foi de $-1,18 \%$ ao ano. O caju foi a cultura que mais absorveu área nesse período, $32,6 \%$ das áreas cedidas pelas outras culturas (Tabela 5 ) . O efeito localização geográfica negativo $(-1,66 \%$ ao ano) significa que aumentou a participação de microrregiões com menor produtividade na área total cultivada com essa cultura.

O único subperíodo em que o caju apresentou taxa de crescimento da produção positiva e elevada foi entre 1985 e 1989, com uma taxa anual de 55,09\% (Tabela 11), explicado principalmente pelo ganhos de produtividade $(E R=51,27 \%$ ao ano) e em uma proporção menor pelo aumento de área (EA=7,48\% ao ano). Esse comportamento pode ter sido resultado dos incentivos governamentais dados a cultura no início dos anos 80 , como também pela regularidade climática e pelo comportamento estável dos preços recebidos pelos produtores. Os componentes explicativos do efeito área tiveram sinais opostos, sendo que o efeito substituição teve uma taxa com uma magnitude maior ( $11,53 \%$ ao ano), o que contrabalançou a diminuição na área plantada (efeito escala $=-4,05 \%$ ao ano). $\mathrm{O}$ efeito localização geográfica com sinal negativo $(-3,66 \%$ ao ano $)$ deve-se ao fato dessa cultura ter-se deslocado, concentrando-se em regiões de menor produtividade relativa.

Entre 1981 e 1985 a produção decresceu com uma taxa de $-2,16 \%$ ao ano (Tabela 10), verificando um efeito rendimento negativo de $-6,38 \%$ ao ano. O efeito área de $3,86 \%$ ao ano e o localização geográfica de $0,36 \%$ ao ano atenuaram, em parte, a queda na produtividade. O mesmo aconteceu no subperíodo de 1989-92, com um declínio na produção de $-5,08 \%$ ao ano (Tabela 12 ), fortemente associado à queda na produtividade $(E R=-17,82 \%$ ao ano), e, em menor grau, pelo efeito localização 
geográfica $(-1,34 \%$ ao ano). O efeito área de $14,08 \%$ ao ano contrapõe, em parte, a conseqüència da queda do rendimento.

Além da influência climática, esses resultados negativos obtidos podem ter sido influenciados pela utilização de mudas de cultivares tardias, o não combate à praga, capina não realizada. Tudo isso prejudica bastante a produção e conseqüentemente a produtividade, já que o comportamento dos preços recebidos pelos produtores foi relativamente estável.

Essa cultura tem grande importância socioeconômica para o Estado, contribuindo com uma parcela significativa na absorção de mão-de-obra, tanto no campo como na indústria e na geração de divisas. É um importante produto de exportação, tanto do suco como das amèndoas e do líquido da castanha do caju. O caju passou a despertar interesse a partir dos anos 70 , no qual foram feitos altos investimentos. Atualmente existe no Estado um significativo parque industrial, com diversas unidades de beneficiamento de castanha e de processamento do pedúnculo, o qual comercializam internamente.

Apesar da sua importância no Estado, o caju apresenta baixos índices de produtividade ( $240 \mathrm{~kg} / \mathrm{ha}$ de castanha), em decorrência da heterogeneidade do material genético, a ocorrência de pragas e doenças, cultivo em solos inadequados, manejos inadequados da cultura e a irregularidade das chuvas. A partir de 1992, o governo estadual elaborou um programa de recuperação e expansão da cultura que consiste em promover o aumento da produção e produtividade do cajueiro, com o objetivo de aumentar a renda dos produtores. O pacote tecnológico indicado foi o da substituição da copa dos cajueiros improdutivos com enxerto do cajueiro "precoce-2", aliado à comercialização dessas mudas enxertadas, treinamento de pessoal, assistência técnica e combate às pragas.
Abacaxi
O abacaxi apresentou um acréscimo na produção a uma taxa média anual de 13,03\%, entre 1981 e 1992. Dos efeitos explicativos obtidos a partir da utilização do modelo "shift-share" (área, rendimento e localização geográfica), destacam-se os efeitos 
área ( $11,97 \%$ ao ano) e rendimento ( $1,33 \%$ ao ano). O efeito localização geográfica foi negativo, porém com pequena magnitude $(-0,27 \%$ ao ano). Isso indica que a cultura teve a proporção da área total cultivada no Estado aumentada em regiões que apresentam menores índices de produtividade (Tabela 9). Os componentes explicativos do efeito área (efeitos escala e substituição) revelam que o abacaxi substituiu áreas de outras culturas no período considerado, já que o efeito substituição foi de $13,27 \%$ ao ano.

A análise dos subperiodos 1981-1985 e 1985-1989 permite verificar um elevado crescimento da produção dessa cultura, com expressivas taxas médias anuais de crescimento de $9,1 \%$ e $43,19 \%$ respectivamente (Tabelas 10 e 11 ). No primeiro subperíodo (1981-85), o efeito explicativo de maior peso foi o efeito área $(7,93 \%$ ao ano), vindo em seguida o efeito rendimento ( $1,18 \%$ ao ano), e o efeito localização geográfica apresentou uma participação quase nula de $-0,01 \%$ ao ano. Ambos os componentes explicativos do efeito área (escala e substituição) contribuíram positivamente para o aumento da área plantada com o abacaxi, cujos resultados obtidos pelos componentes foram $6,31 \%$ e $1,62 \%$ ao ano, respectivamente.

No segundo subperíodo (1985-89), a taxa média anual de crescimento da produção também é explicada em sua maior parte através do efeito área $(34,95 \%$ ao ano). O efeito rendimento apresentou uma magnitude de $9,42 \%$ ao ano e o efeito localização geográfica foi de $-1,18 \%$ ao ano, mostrando que essa cultura cresceu mais em regiões de produtividade mais baixa.

Entre 1989 e 1992 ocorreu uma queda na produção, com uma taxa média anual de decréscimo de $-13,54 \%$. O componente explicativo de maior peso foi o efeito área $(-10,01 \%$ ao ano), seguido do efeito rendimento $(-3,44 \%$ ao ano). O efeito localização geográfica participou com uma taxa de $-0,09 \%$ ao ano.

Essa cultura passou a ser cultivada no Rio Grande do Norte principalmente devido à crise da produção no Estado da Paraiba, com problemas de doenças nas frutas, além da boa adaptação da cultura, a evolução satisfatória dos preços recebidos pelos agricultores, e o bom período de chuva terem também contribuído para expansão dessa cultura no Estado. A cultivar mais plantada é a "pérola". 
Das microrregiões produtoras, o Agreste Potiguar é o maior produtor. $\mathrm{O}$ Litoral de São Bento Norte, que ocupava o quarto lugar em área plantada em 1981, passou para o segundo em 1992, invertendo as posições com a região de Natal. E a microrregião de Serra Verde continuou com sua terceira colocação em área plantada. Em 1992, foram cultivados cerca de 1.564 hectares, com uma produtividade média de 21 mil frutos/ha. No Estado, $80 \%$ dos abacaxicultores são pequenos produtores, com área variando entre 0,5 e 5 ha. É uma atividade de grande importância socioeconômica, pois além de aumentar a renda do produtor e gerar divisas, tem a capacidade de gerar emprego para mão-de-obra durante todos os meses do ano

\section{Feijão}

Entre 1981 e 1992, a produção de feijão cresceu a uma taxa média anual elevada de $12,1 \%$. Isso se explica basicamente pelo crescimento do rendimento $(\mathrm{ER}=$ $10,47 \%$ ao ano), e em menor grau, pelo efeito área de $0,54 \%$ ao ano e o efeito localização geográfica de $1,09 \%$ ao ano, indicando que a cultura teve a proporção da área total cultivada no Estado aumentada nas regiões que apresentam maiores índices de produtividade. Fatores que podem ter contribuido para o aumento da produtividade foram a introdução e recomendação de variedades melhor adaptadas ao clima e solo, com também a maior disponibilidade e uso de sementes com origem e de qualidade controlada.

Entre 1981 e 1985 foi o subperíodo de maior crescimento da produção, com uma taxa média anual de $54,85 \%$, tendo como principal componente explicativo o efeito rendimento com $50,59 \%$ ao ano, seguido do efeito área de $7,95 \%$ ao ano. Isso pode ter ocorrido tanto devido aos bons índices pluviométricos, como pelos aumentos dos preços recebidos pelos agricultores, ocorridos nos anos de 1984 a 1986. Analisando os componentes explicativos do efeito área, tanto o efeito substituição ( $4,61 \%$ ao ano) como o efeito escala $(3,34 \%$ ao ano) contribuiram de forma proporcional para a expansão de área.

No subperíodo seguinte (1985-89), a produção apresentou um decréscimo de $-9,78 \%$ ao ano. Todos os componentes explicativos obtidos (área, rendimento e 
localização geográfica) apresentaram um sinal negativo, sendo de $-7,33 \%,-2,33 \% \mathrm{e}$ $-0,12 \%$ ao ano, respectivamente.

Entre 1989 e 1992, a produção continuou em declínio, com uma taxa média anual de $-2,67 \%$, devido principalmente à retração de área ( $\mathrm{EA}=-4,02 \%$ ao ano). A redução no volume produzido nesse período não foi mais acentuado devido a evolução favorável do efeito rendimento ( $1,2 \%$ ao ano) e do efeito localização geográfica $(0,15 \%$ ao ano), que contrabalançaram a retração na área dessa cultura. Essa retração de área pode ter sido influenciada pelos baixos indices de chuvas, já que, analisando a evolução dos preços recebidos pelos produtores, esses apresentaram um comportamento crescente.

O feijão é uma cultura de grande importância na agropecuária norteriograndense, servindo de base alimentar como fonte protéica e energética para grande parte da população urbana e rural de baixa renda. O feijão "caupi” é amplamente cultivado no Estado, participando aproximadamente $93 \%$ do total produzido. Essa cultura ocupava $15,5 \%$ da área plantada no início da década de 80 , tendo crescido significativamente para 24,1\% no começo dos anos 90, isto é, 139 mil hectares, ocupando o primeiro lugar em área plantada entre as culturas analisadas. Cultivado em todas as microrregiões, em 1981, as principais regiões em área plantada $(76,3 \%) \mathrm{e}$ produção $(77,3 \%)$ eram Açu-Apodi, Seridó, Serrana Norte-riograndense, Agreste Potiguar e Borborema Potiguar. E em 1992 ocorreram algumas mudanças nas regiões produtoras, ou seja, as microrregiões da Borborema Potiguar, Agreste Potiguar, Serrana Norte-riograndense, Açu-Apodi e Salineira Norte-riograndense passaram a responder por $72 \%$ da área plantada e $76 \%$ da produção estadual.

O Rio Grande do Norte, comparado com outros Estados, apresenta uma produtividade muito baixa, variando de 66 a $450 \mathrm{~kg} / \mathrm{ha}$, devido a diversos fatores, dos quais destacam-se a situação cultural e econômica do produtor, as adversidades climáticas, a não utilização de tecnologias mais apropriadas, notadamente o baixo uso de sementes selecionadas, o não combate às pragas e doenças, e a instabilidade nos preços recebidos pelos produtores. 


\section{Sorgo}

Apesar de pouco expressiva, em termos de área (6.800 ha), a cultura do sorgo apresentou uma elevado crescimento na produção de $11,56 \%$ ao ano, no período de 1981 a 1992. Os principais componentes da taxa média anual de variação da produção foram o efeito área de $8,78 \%$ ao ano e o efeito rendimento de $3,08 \%$ ao ano, mostrando uma evolução favorável dessa cultura no periodo estudado. $O$ efeito localização geográfica foi de $-0,30 \%$ ao ano. Dentre os componentes explicativos do efeito área, destaca-se o efeito substituição de $4,49 \%$ ao ano.

Entre 1981 e 1985, verifica-se a maior taxa média de crescimento da produção em torno de $59,29 \%$ ao ano, explicada na sua maior parte, através do efeito rendimento (39,50\% ao ano). O efeito área apresentou um valor expressivo de $19,10 \%$ ao ano e o efeito localização foi de $0,69 \%$ ao ano.

No segundo subperíodo (1985-89), a taxa média anual de crescimento na produção sofreu um declínio, passando para $1,46 \%$ ao ano, em função da retração na área ( $\mathrm{EA}=-3,47 \%$ ao ano) e do efeito localização de $-0,55 \%$ ao ano, mostrando que essa cultura passou a crescer mais em regiões de produtividade menores. $O$ efeito rendimento de $5,48 \%$ ao ano amenizou as taxas negativas dos efeitos área e localização geográfica. A queda foi maior no terceiro subperiodo analisado (1989-92) com uma taxa de -21,25\% ao ano, sendo que os efeitos área, rendimento e localização geográfica participaram com $-13,01 \%,-7,19 \%$ e $-1,05 \%$ ao ano, respectivamente.

No Rio Grande do Norte, o sorgo é cultivado em praticamente todas microrregiões, merecendo destaque em termos de área plantada ( $88 \%$ ) e produção (86\%) as microrregiões: Salineira Norte-riograndense era e continua sendo o principal produtor; Serra Verde, de terceiro produtor em 1981, passou a ser o segundo em 1992; Litoral de São Bento do Norte, onde praticamente não se plantava, ficou no quarto lugar em 1992; e Sertão de Angicos, que da quinta colocação passou para a terceira posição em área plantada em 1992. Açu-Apodi, que era a segunda maior área plantada em 1981, passou a ocupar a sexta colocação em 1992. O cultivo é feito predominantemente no sistema solteiro, sem contudo desprezar o consorciado. As cultivares recomendadas são IPA-860 2527, IPA-860 2502 e IPA-467-4-2. 


\section{Arroz}

A taxa de crescimento da produção do arroz no período 1981-92 fói de $7,46 \%$ ao ano. Entre 1981 e 1985, a variação da produção foi de 58,99\% ao ano, passando a declinar a taxas de $-12,07 \%$ e $-16,72 \%$ ao ano, nos dois subperíodos posteriores (1985-89 e 1989-92). O decréscimo na produção nesses dois subperíodos é devido basicamente à retração de área $(\mathrm{EA}=-13,82 \%$ a.a. e $\mathrm{EA}=-13,87 \%$ a.a. respectivamente). Essa queda na área plantada pode está associada aos baixos índices de chuvas dos anos 90 , pela baixa tecnologia utilizada, como também pela queda nos preços recebidos pelos produtores de arroz.

Entre 1985 e 1989, o efeito rendimento contribuiu com $0,33 \%$ ao ano, e o efeito localização geográfica também foi positivo e de magnitude não desprezivel de $1,42 \%$ ao ano, sendo um indicador de que a produção do arroz vem sendo beneficiada pela existência de vantagens locacionais comparativas, associadas à concentração da produção na microrregião Serrana Norte-riograndense. Esse último efeito continua positivo e elevado ( $2,54 \%$ a.a.) no subperiodo seguinte (1989-92). O efeito rendimento ocupa papel importante entre as fontes de crescimento, tanto no subperiodo 1981-85 ( $E R=52,74 \%$ a.a. $)$ quanto no período $1981-92(E R=9,01 \%$ a.a. $)$.

As áreas produtivas de arroz no Estado estão inseridas nas microrregiões Serrana Norte-riograndense, Seridó e Açu-Apodi, contribuindo em 1992 com 99\% da área plantada e da produção estadual, sendo cultivado em sua maioria em regime de sequeiro. Em 1981 eram essas mesmas regiões, só que a Serrana Norte-riograndense ocupava o segundo lugar em área plantada, e o Seridó, o primeiro. A área cultivada oscila em torno de 4.000 ha, com uma produtividade média de $1.300 \mathrm{~kg} / \mathrm{ha}$, e a produção atende somente a $10 \%$ da demanda do Estado. Cerca de $83 \%$ da área plantada é cultivada por pequenos proprietários. As variedades indicadas pela pesquisa são a CICA8, a METICA-1 e a CICA-9, essa última para o cultivo irrigado. Utilizando-se a tecnologia indicada, a produtividade pode chegar a $9.000 \mathrm{~kg} / \mathrm{ha}$. 


\section{Coco-da-baía}

A taxa média de variação da produção do coco-da-baía foi de $5,99 \%$ ao ano, entre 1981 e 1992, basicamente explicado pelo aumento de área $(E A=8,36 \%$ ao ano), principalmente devido ao efeito substituição de $10,26 \%$ ao ano. $O$ efeito rendimento apresentou-se negativo $(-3,12 \%$ ao ano), e o efeito localização geográfica foi de apenas $0,75 \%$ ao ano.

No primeiro subperíodo (1981-85), o aumento na produção foi um pouco superior de $7,18 \%$ ao ano, com relação ao período total. Os principais componentes explicativos da taxa média anual de variação da produção foram o efeito área de $6,43 \%$ ao ano e o efeito rendimento de $1,28 \%$ ao ano. No subperíodo seguinte (1985-89), ocorreu um pequeno decréscimo na produção $(-0,22 \%$ ao ano), apesar da expansão da área $(\mathrm{EA}=9,08 \%$ ao ano). Essa expansão de área foi superada pelos efeitos negativos do rendimento e da localização geográfica, que foram respectivamente, de $-8,74 \%$ e $0,56 \%$ ao ano.

Entre 1989 e 1992, o coco-da-baía teve sua produção acrescida a uma taxa média anual de $13,15 \%$. Dos efeitos explicativos obtidos a partir da utilização do modelo "shift-share" (área, rendimento e localização geográfica), destacam-se os efeitos área $(8,34 \%$ ao ano) e o rendimento $(4,41 \%$ ao ano). O efeito localização geográfica também foi positivo, porém com uma menor magnitude $(0,4 \%$ ao ano). Esse resultado indica que a cultura teve a proporção da área total cultivada no Estado aumentada em regiões que apresentam maiores indices de produtividade. Dos componentes explicativos do efeito área, o efeito substituição foi de $12,54 \%$ ao ano (Tabela 12), revelando que o coco-da-baía incorporou áreas de outras atividades agricolas.

Em 1992, o coco-da-baía ocupou uma área de aproximadamente 35 mil hectares, com uma produtividade média de 3.000 frutos/ha. Assim como o cajueiro, o coqueiro é uma cultura típica da região litorânea, tendo sua produção concentrada nas microrregiões do Litoral de São Bento do Norte e Natal, responsáveis por $89 \%$ da área plantada e da produção estadual. Entre 1981 e 1992, o Litoral de São Bento do Norte aumentou sua participação na área plantada e na produção estadual, e a região de Natal diminuiu (era o primeiro produtor em 1981). Também é explorada, na sua maioria, por 
grandes proprietários. Do coqueiral plantado no Estado $90 \%$ é do tipo "gigante", bastante utilizado pela indústria. A partir de 1990, os produtores começaram a plantar as cultivares "híbrida" e "anão verde" (10\%), a primeira para atender a expansão da área, como também para substituir os coqueirais antigos de baixa produtividade, e a segunda destinada para o consumo de água de coco.

\section{Cana-de-açúcar}

Entre 1981 e 1992, a cana-de-açúcar apresentou produção crescente, a uma taxa anual de $1,23 \%$, apesar da redução do rendimento ( $E R=-1,6 \%$ ao ano). $O$ efeito área de $2,65 \%$ ao ano foi superior à taxa de crescimento da produção.

A cultura canavieira no Estado concentra-se na microrregião de Natal, responsável por $90 \%$ dos 55 mil hectares plantados, onde também se concentram as agroindústrias de transformação. O cultivo se realiza nos vales úmidos dos rios e nos tabuleiros costeiros, e a exploração é feita em regime de grande propriedade. Em 1992 ocupava o quarto lugar em área plantada no Estado, com uma produtividade média de 45 mil $\mathrm{kg} / \mathrm{ha}$.

Ao considerar os subperíodos, percebe-se que a maior taxa média anual de crescimento da produção $(6,92 \%)$ ocorreu entre 1981 e 1985, explicada em sua maior parte através do efeito área $(6,44 \%$ ao ano), devido principalmente ao efeito escala $(6,52 \%)$. Os efeitos rendimento e localização geográfica tiveram magnitudes explicativas pequenas de $0,32 \%$ e $0,16 \%$ ao ano, respectivamente.

No segundo subperiodo (1985-89), a taxa média anual de crescimento da produção foi de $0,5 \%$, explicado pela queda de produtividade ( $E R=-1,46 \%$ ao ano), cujo efeito foi atenuado pela expansão de área $(E A=1,75 \%$ ao ano). Nesse período, essa cultura foi responsável por absorção de 14,7\% das áreas cedidas pelas demais culturas (Tabela 7). E no terceiro subperiodo analisado (1989-92), a taxa anual de crescimento da produção foi negativa de $-4,98 \%$, sendo que os efeitos área, rendimento e localização geográfica participaram com $-1,67 \%,-3,35 \%$ e $0,04 \%$ ao ano, respectivamente. Esse declínio na produção pode estar refletindo a retração dos 
produtores de cana, em virtude principalmente do comportamento declinante dos preços recebidos pelos produtores, como também pelos altos juros do crédito.

\section{Manga}

Entre 1981 e 1992, o crescimento da produção da manga foi de $0,03 \%$ ao ano, explicada em grande parte pela expansão na área ( $E A=1,28 \%$ ao ano), cujo efeito é atenuado devido à queda na produtividade $(E R=-0,78 \%$ ao ano) e pelo deslocamento da cultura para regiões com baixa produtividade ( $E L G=-0,47 \%$ ao ano).

Em 1992, o total da área plantada foi de 2.000 ha, com uma produtividade de 37 mil frutos/ha. O cultivo da manga concentra-se na microrregião de Natal e AçuApodi. Em todo o período analisado, a maior região produtora foi a de Natal. AçuApodi passou de quarta para segunda maior área plantada. A terceira colocação pertence à região Agreste Potiguar que ocupava o segundo lugar em 1981. Seridó que era a terceira área, passou para quarta.

$\mathrm{O}$ único subperíodo em que essa cultura apresentou uma taxa de crescimento da produção negativa $(-0,85 \%$ ao ano) foi entre 1981 e 1985 , principalmente devido à retração de área $(\mathrm{EA}=-1,26 \%$ ao ano). O efeito substituição de $-8,58 \%$ ao ano contribuiu de modo decisivo para isso, superando o efeito escala de $7,32 \%$ ao ano. $\mathrm{O}$ efeito rendimento foi de $0,43 \%$ ao ano.

No segundo subperiodo (1985-89), a produção cresceu a uma taxa anual de $0,6 \%$, tendo como componente explicativo de maior peso o efeito rendimento de $1,64 \%$ ao ano, vindo em seguida o efeito área com $0,28 \%$ ao ano. O efeito localização geográfica de $-1,32 \%$ ao ano, contrapondo em parte as conseqüências dos aumentos acima, mostra que essa cultura cresceu mais em regiões de produtividade mais baixa.

O mesmo aconteceu entre 1989 e 1992, com uma taxa de crescimento médio anual da produção girando em torno de $0,45 \%$. Teve como principal efeito explicativo a expansão de área $(\mathrm{EA}=6,21 \%$ ao ano), suavizando, em parte, os resultados negativos dos efeitos rendimento $(-5,53 \%$ ao ano $)$ e localização geográfica $(-0,23 \%$ ao ano $)$. 
Apesar do Rio Grande do Norte estar entre os três maiores produtores e apresentar condições propícias para o cultivo da manga, sua produtividade é baixa e a qualidade da produção deixa a desejar. Apenas no final dos anos 80 é que a cultura tomou novas proporções, com a introdução de cultivares para exportação, o uso de tecnologias intensivas, e a expansão como cultura irrigada.

\section{Algodão Arbóreo}

O algodão arbóreo detinha 34,3\% da área plantada do Estado em 1981 (276 mil hectares), mas essa proporção caiu drasticamente de forma persistente, atingindo 1,6\% da área plantada em 1992 (8.900 hectares). As microrregiões que se destacam em área plantada são: Seridó que continua a possuir a maior área; Serrana Norte-riograndense, que ocupava o terceiro lugar no início da década, passou para o segundo em área plantada em 1992; Borborema Potiguar, que ocupava o segundo lugar, passou para quinto em 1992; Sertão de Angicos de quarta passou para terceira maior área; e Serra Verde, que da sexta colocação passou a ter a quarta maior área plantada no Estado.

No período total analisado, o algodão arbóreo ficou em primeiro lugar em retração de área entre as culturas que cederam áreas. A taxa média anual de variação da produção foi de $-22,18 \%$, entre 1981 e 1992, explicado basicamente pela redução na área (efeito área $=-22,92 \%$ ao ano), dos quais o efeito substituição responde com o maior grau de explicação $(-16,2 \%$ ao ano) e o efeito escala com $-6,72 \%$ ao ano. Esses resultados são similares aos obtidos no subperiodo 1985-89, quando o "bicudo" se generalizou como praga neste algodoeiro, e o agricultor passou a ter mais dificuldades na exploração, devido ao total desconhecimento da nova praga e dos meios para combatê-la.

A maior queda da produção foi detectada no subperíodo 1989-92, com uma taxa de variação da produção de $-47,59 \%$ ao ano, sendo explicado essencialmente pelo efeito área $(-50,36 \%$ ao ano); o efeito substituição contribuiu com $-42,4 \%$ ao ano e o escala, com $-7,96 \%$ ao ano. Esses resultados provavelmente foram influenciados tanto pela propagação do bicudo, a baixa produtividade, como também, pela queda dos preços 
recebidos pelos produtores, verificada a partir de 1990, aliados à seca que atingiu a região nos anos 90 .

Entre 1981 e 1985, foi o único período que a cultura do algodão apresentou um razoável crescimento na produção de $4,69 \%$ ao ano, tendo como principal elemento explicativo o efeito rendimento, de $5,18 \%$ ao ano. Os efeitos área e localização geográfica foram de $0,68 \% \mathrm{e}-1,17 \%$ ao ano, respectivamente.

Como pode ser verificado, o algodoeiro arbóreo, produtor de fibras longa e extra-longa, está passando por um período de estagnação. Este declínio começou na seca ocorrida entre 1979 e 1983, logo depois veio a praga do bicudo (1987 o pico do ataque), culminando com os baixos preços de mercado da fibra, crédito rural com juros muito altos aliado à baixa produtividade. Representava até 1978 o principal suporte do setor agricola estadual, contribuindo com $40 \%$ do ICM arrecadado, significativa participação no valor bruto da produção agricola e ocupava cerca de $35 \%$ da mão-deobra rural, além de sua participação na alimentação animal, seja na oferta de ração concentrada (torta), seja no aproveitamento dos restos da cultura. O algodão arbóreo e a pecuária foram o agente decisivo de ocupação das terras secas do semi-árido norteriograndense.

O governo estadual tem se empenhado na recuperação dessa cultura, apoiado principalmente no controle do bicudo, na distribuição de semente de boa qualidade (semente fiscalizada) e no aumento da produtividade, através dos seus órgãos de pesquisa e extensão, como também através do acesso ao crédito rural. Dentre as cultivares recomendadas pela pesquisa para o algodão arbóreo, destacam-se CNPA-3M, CNPA-4M, CNPA-9M, EMPARN-1 e EMPARN-2. A cultura do algodão é produzida principalmente em grandes propriedades, sob relações de produção assalariada ou em parceria.

Aliada aos problemas citados acima, segundo Moreira (1995), a crise do algodão é agravada pela redução da tarifa de importação, além dos preços internacionais muito baixos, que permite a entrada no mercado nacional do algodão de diversos países, em muitos dos quais o produtor é subsidiado, podendo assim comercializar a preços mais baixos que os preços internos, além das vantagens de prazo no pagamento e das baixas 
taxas de juros cobradas, desestimulando, assim, a produção interna, tanto do algodão como dos produtos têxteis. Este declínio da produção do algodoeiro foi verificado em todo o Brasil, sendo que a redução de área mais drástica ocorreu na região Nordeste. Em 1980 esta região tinha 3,3 milhões de hectares plantados, passando para 555 mil hectares em 1995 (Bolsa de Mercadorias \& Futuros, 1996). Os mesmos fatores citados anteriormente (a praga do bicudo, problemas climáticos, preços e juros baixos do mercado internacional, falta de crédito, câmbio compensador e alíquota baixa de importação) prejudicaram tanto os produtores estaduais como nacionais.

\section{Sisal}

No periodo total analisado (1981-92), o sisal ocupou o terceiro lugar em retração de área entre as culturas que cederam áreas. A taxa de variação da produção de $-11,93 \%$ ao ano, é explicada basicamente pela redução na área (efeito área $=-13,92 \%$ ao ano). Os componentes explicativos do efeito área (efeitos escala e substituição) revelam que o sisal cedeu áreas para outras culturas, uma vez que o efeito substituição foi de $-9,42 \%$ ao ano. O efeito escala foi de $-4,5 \%$ ao ano.

Comportamento similar foi obtido no subperiodo $1985-89$, no qual a taxa média anual de crescimento foi de $-17,38 \%$, sendo que os efeitos área, rendimento e localização geográfica participaram com $-24,91 \%, 5,77 \%$ e $1,76 \%$ ao ano, respectivamente.

No subperíodo seguinte (1989-92), verifica-se a maior queda na produção, com uma taxa média anual de decréscimo em torno de $-24,33 \%$. O efeito explicativo de maior peso continuou sendo o efeito área com $-21,01 \%$ ao ano, seguido agora com uma menor magnitude do efeito rendimento $(-3,11 \%$ ao ano $)$ e do efeito localização geográfica $(-0,21 \%$ ao ano $)$.

No primeiro subperíodo (1981-1985), a cultura do sisal obteve um razoável crescimento na produção de $5,22 \%$ ao ano. Os principais componentes explicativos da taxa média de variação da produção foram o efeito rendimento de $4,9 \%$ ao ano e o efeito área com $0,32 \%$ ao ano. 
Anteriormente, o sisal ocupava uma posição de destaque entre os principais produtos agricolas do Estado, sendo o terceiro produtor nacional, cuja produção se destinava praticamente ao mercado externo. As maiores áreas cultivadas estavam nas regiões do Litoral de São Bento do Norte, Serra Verde e Borborema Potiguar, em ordem decrescente. No período analisado, entretanto, entrou em declínio. A crise econômica brasileira dos anos 80 , o fechamento do mercado externo para essa cultura, a falta de incentivos do governo, a ausência de preços mínimos, foram sem dúvida os maiores determinantes desse declínio. O sisal que detinha uma área plantada no Estado em 1981, de 4,3\% (35 mil hectares), caiu de forma persistente para atingir 0,7\% (4 mil hectares), em 1992. Atualmente, Serra Verde e Borborema Potiguar são principais microrregiões produtoras. O Litoral de São Bento do Norte passou a ter uma participação muito pequena na área cultivada de sisal.

\section{Batata-doce}

A batata-doce teve tendência declinante na produção em todos os subperíodos analisados, explicados em sua maior parte pela retração da área plantada e pela queda na produtividade. O efeito localização também foi negativo nos subperiodos, mas com baixa magnitude. Entre 1981 e 1992, a produção decresceu a uma taxa anual de $-7,17 \%$. O efeito área $(-6,53 \%$ ao ano) explicou $91 \%$ da variação na produção nesse período. Os efeitos rendimento e localização geográfica foram de $-0,48 \%$ e $-0,16 \%$ ao ano, respectivamente.

Tanto em 1981 como em 1992, as principais microrregiões produtoras foram as mesmas, só que trocaram de posição: Natal, de terceiro passou para primeira maior área; Seridó, de primeiro passou para segundo colocação; Agreste Potiguar, de quarto passou para terceiro lugar; e Açu-Apodi, de segundo passou para quarto. A área média plantada no Estado é de 3.600 ha, com uma produtividade média de $6.000 \mathrm{~kg} / \mathrm{ha}$. É uma cultura de vazante, prática tradicional no Rio Grande do Norte, que consiste em se plantar nos leitos de rio e margens de açudes à medida que a água vai baixando e descobrindo as terras. Não obstante a tradição, as produtividades são baixas pela falta de 
tecnologias mais favoráveis. Geralmente plantada em consórcio com capim elefante e feijão, a variedade recomendada é "Dedinho".

\section{Algodão herbáceo}

Em 1981, o algodão herbáceo representava $17,5 \%$ da área plantada ( 140 mil hectares) do Estado, passando para 4,3\% (25 mil hectares) em 1992. No periodo total analisado (1981-1992), essa cultura ocupou o segundo lugar em retração de área, apresentando uma taxa anual de crescimento da produção negativa $(-6,29 \%$ ao ano), sendo que o efeito área teve participação principal na redução da produção, de $-10,15 \%$ ao ano, enquanto o efeito rendimento teve uma taxa positiva de $3,89 \%$ ao ano, podendo ser resultado das novas cultivares lançadas pela pesquisa. Os componentes explicativos do efeito área (efeitos substituição e escala), assumiram valores de $-6,65 \%$ e $-3,50 \%$ ao ano, respectivamente (Tabela 9). Esses resultados são similares aos obtidos no subperíodo 1989-92.

O segundo subperiodo analisado (1985-89) foi que apresentou a maior queda da produção, com uma taxa de $-23,88 \%$ ao ano, sendo explicado basicamente pelo efeito área de $-26,74 \%$ ao ano. Analisando os componentes explicativos do efeito área, verifica-se que é nesse período que se localiza o maior grau de substituição dessa cultura ( $-14,09 \%$ ao ano), tendo um efeito escala de $-12,64 \%$ ao ano. Os efeitos rendimento e localização geográfica contribuíram com 1,72\% e 1,14\% ao ano, respectivamente.

No primeiro subperíodo (1981-1985), a taxa média anual de crescimento da quantidade produzida do algodão herbáceo foi de 13,56\%. Dos efeitos explicativos obtidos a partir do modelo "shift-share" (área, rendimento e localização geográfica), destaca-se principalmente o efeito rendimento com $16,09 \%$ ao ano. Os efeitos área e localização geográfica tiveram taxas negativas de $-1,22 \%$ e $-1,31 \%$ ao ano, respectivamente.

Esta análise reflete as mudanças ocorridas ao longo do periodo na cultura do algodoeiro, com uma queda na área plantada em todos os subperíodos analisados, devido a problemas climáticos, praga do bicudo, baixos preços no mercado internacional e à falta de uma política agrícola e comercial, mas, apesar destes problemas, o 
comportamento do rendimento foi inverso, provavelmente explicado pelo avanço da tecnologia da produção estadual.

Essa cultura teve, portanto, uma tendência declinante semelhante à do algodão arbóreo, só que em menores proporções. O algodão herbáceo produtor de fibras curta e média, assim como o algodoeiro arbóreo, chegou a desempenhar um relevante papel socioeconômico, notadamente no semi-árido, com uma elevada utilização de mãode-obra, tanto na agricultura como nas indústrias de beneficiamento instaladas na região. Os problemas climáticos, a falta de política de crédito rural compatível, a infestação da cultura pelo bicudo e a concorrência do algodão importado aprofundaram ainda mais a redução na área plantada estadual, com impacto na economia do setor industrial, criando também um grande problema social pela desocupação da mão-de-obra empregada na atividade.

As cultivares recomendadas pela pesquisa são CNPA-Precoce 2, IAC-20 e Acala 1 (irrigação). Cultivada em todas as microrregiões, mas considerando as principais regiões produtoras, percebe-se ocorreram modificações quanto à posição, pois em 1981 a região com maior área plantada era o Agreste Potiguar, seguida pela Serrana Norteriograndense, Açu-Apodi e Borborema Potiguar. E em 1992, passaram a ser em ordem decrescente de área plantada as regiões de Açu-Apodi, Salineira Norte-riograndense, Serrana Norte-riograndense e Borborema Potiguar.

\section{Mandioca}

Essa cultura apresentou um comportamento declinante no período 1981 a 1992, com uma taxa média anual de variação da produção de $-2,91 \%$. Essa taxa negativa deve-se tanto à retração de área (EA $=-1,80 \%$ ao ano), como ao declínio da produtividade ( $\mathrm{ER}=-1,04 \%$ ao ano). O efeito localização geográfica também foi negativo $(-0,07 \%$ ao ano). $\mathrm{Na}$ decomposição do efeito área em componentes explicativos, o efeito escala foi de $-2,98 \%$ ao ano, superando amplamente o efeito substituição de $1,18 \%$ ao ano.

Entre 1981 a 1985, a cultura da mandioca obteve uma taxa média anual de crescimento da produção de $0,73 \%$, explicado principalmente pelo aumento da 
produtividade ( $E R=1,28 \%$ ao ano) e pelo efeito localização geográfica de $0,3 \%$ ao ano. A retração de área $(E A=-0,85 \%$ ao ano) suavizou o efeito desses dois componentes. Nos dois subperíodos subseqüentes (1985-89 e 1989-92) a produção da mandioca entra em declínio, com taxas de $-3,17 \%$ e $-7,26 \%$ ao ano, respectivamente, com todos os efeitos contribuindo para esse declínio.

A mandioca também é outro produto tradicional da agricultura norteriograndense, muito utilizado na alimentação da população local e da pecuária. A farinha de mandioca é produto freqüente na mesa da população, principalmente de baixa renda. A produção concentra-se nas microrregiões do Agreste Potiguar, Natal, Borborema Potiguar e Seridó, contribuindo com $78 \%$ da área plantada, praticada por pequenos e médios produtores. O nível tecnológico é insuficiente e a produtividade está abaixo da média nacional. Os principais problemas que fazem cair sensivelmente a produção e a produtividade são os ataques de pragas, os baixos preços das matérias-primas e o uso de cultivares duvidosas.

\section{Banana}

A plantação da banana concentra-se nos vales úmidos das microrregiões de Natal, Açu-Apodi e Serrana Norte-riograndense. Em 1992, plantaram-se em torno de $3000 \mathrm{ha}$, tendo uma produtividade média de $1.300 \mathrm{cachos} / \mathrm{ha}$. As variedades mais utilizadas pelos produtores são a "nanica" e a "pacovan". Essa cultura teve um comportamento decrescente em praticamente todos os períodos analisados. Para o periodo todo (1981-92), a taxa anual de crescimento da produção foi de $-1,87 \%$. O efeito rendimento foi de $-1,21 \%$ ao ano, explicando a maior parte do decréscimo na produção, seguido do efeito área com $-0,67 \%$ ao ano. E o efeito localização geográfica teve uma participação quase nula de $0,01 \%$ ao ano.

Os melhores rendimentos dessa cultura são obtidos quando as chuvas se distribuem uniformemente durante todo o ano, com precipitação mensal média na ordem de 100 a $150 \mathrm{~mm}$, o que não ocorreu no periodo analisado, justificando, em parte, esse comportamento decrescente, já que, analisando a evolução dos preços recebidos pelos produtores, percebe-se que foram praticamente constantes, com exceção da alta de 1989. 
Essa cultura foi recentemente estimulada devido à expansão da irrigação no Estado e adoção de tecnologias mais avançadas pelos produtores.

\subsection{Análise por microrregião para o conjunto das culturas}

As microrregiões de rápido crescimento da produção, isto é, que apresentaram taxas médias anuais de crescimento da produção elevadas e positivas entre 1981 e 1992, foram: Litoral de São Bento do Norte (10,64\%), Serra Verde (9,95\%), Salineira Norte-riograndense (9,66\%), Borborema Potiguar (7,19\%), Sertão de Angicos $(6,86 \%)$, Açu-Apodi $(4,95 \%)$ e a Serrana Norte-riograndense $(2,69 \%)$. Todas as microrregiões acima tiveram crescimento mais acentuado no primeiro subperiodo (198185 ), sendo que as únicas regiões que apresentaram taxas de crescimento positivas em todos os subperíodos analisados foram a Salineira Norte-riograndense e a do Litoral de São Bento do Norte (Tabelas 13 e 16).

Os principais indicadores de crescimento da produção nessas microrregiões, entre 1981 e 1992, são em primeiro lugar as mudanças na composição da produção e, em segundo, o aumento do rendimento, seguidos da expansão de área como foi o caso das regiões Salineira Norte-riograndense e do Litoral de São Bento do Norte. Exceção a esse comportamento é observada nas microrregiões de Açu-Apodi e Serrana Norte-riograndense, onde o rendimento se apresentou como o efeito mais importante no crescimento da produção, provavelmente devido à predominância na região de topografia plana, solos bons e da utilização de tecnologias modernas. Em todas as microrregiões percebe-se uma variação relativa dos efeitos explicativos conforme os subperiodos analisados.

\section{Litoral de São Bento do Norte}

Entre todas as microrregiões analisadas, a região do Litoral de São Bento do Norte foi a que obteve a maior taxa média anual de crescimento da produção (10,64\%) no período de 1981-1992 (Tabela 13). Esta alta taxa de crescimento da produção é explicada, em sua maior parte, através das mudanças na composição da produção ( $\mathrm{ECP}=6,76 \%$ ao ano). O efeito rendimento apresentou apreciável magnitude 
Tabela 13 - Decomposição da taxa média regional e estadual, em efeitos explicativos do crescimento da produção das principais culturas, Rio Grande do Norte, 198192.

\begin{tabular}{lc|c|c|c|c}
\hline \multirow{2}{*}{ Microrregiões/Estado } & \multicolumn{5}{|c}{$1981-92$} \\
\cline { 2 - 6 } & Taxa anual de & \multicolumn{5}{|c}{ Fontes de crescimento (\%) } \\
\cline { 2 - 6 } & $\begin{array}{l}\text { crescimento da } \\
\text { produção (\%) }\end{array}$ & $\begin{array}{c}\text { Efeito } \\
\text { Área }\end{array}$ & $\begin{array}{c}\text { Efeito } \\
\text { Rendimento }\end{array}$ & $\begin{array}{c}\text { Efeito } \\
\text { Composição }\end{array}$ & $\begin{array}{c}\text { Efeito } \\
\text { Localização }\end{array}$ \\
\hline Litoral de São Bento do Norte & 10,64 & 1,74 & 2,14 & 6,76 & - \\
Serra Verde & 9,95 & $-1,04$ & 3,75 & 7,24 & - \\
Salineira Norte-riograndense & 9,66 & 0,95 & 2,50 & 6,21 & - \\
Borborema Potiguar & 7,19 & $-2,37$ & 3,08 & 6,48 & - \\
Sertão de Angicos & 6,86 & $-3,41$ & 4,02 & 6,25 & - \\
Açu e Apodi & 4,95 & $-2,88$ & 4,83 & 3,00 & - \\
Serrana Norte-riograndense & 2,69 & $-4,22$ & 3,87 & 3,04 & - \\
Natal & $-0,22$ & 3,29 & $-1,69$ & $-1,82$ & - \\
Agreste Potiguar & $-3,29$ & $-2,56$ & $-0,34$ & $-0,39$ & - \\
Seridó & $-3,84$ & $-7,41$ & 1,23 & 2,34 & - \\
\hline ESTADO & 1,66 & $-2,37$ & 1,17 & 1,53 & 1,33 \\
\hline
\end{tabular}

Fonte: Dados básicos do Anuário Estatístico do Rio Grande do Norte - FIDEC.

Tabela 14 - Decomposição da taxa média regional e estadual, em efeitos explicativos do crescimento da produção das principais culturas, Rio Grande do Norte, 198185 .

\begin{tabular}{l|c|c|c|c|c}
\hline \multirow{2}{*}{ Microrregiões/Estado } & \multicolumn{5}{|c}{$1981-85$} \\
\cline { 2 - 6 } & Taxa anual de & \multicolumn{4}{|c}{ Fontes de crescimento (\%) } \\
\cline { 3 - 7 } & $\begin{array}{l}\text { crescimento da } \\
\text { produção (\%) }\end{array}$ & $\begin{array}{c}\text { Efeito } \\
\text { Área }\end{array}$ & $\begin{array}{c}\text { Efeito } \\
\text { Rendimento }\end{array}$ & $\begin{array}{c}\text { Efeito } \\
\text { Composição }\end{array}$ & $\begin{array}{c}\text { Efeito } \\
\text { Localização }\end{array}$ \\
\hline Sertão de Angicos & 42,26 & 16,15 & 26,39 & $-0,28$ & - \\
Serrana Norte-riograndense & 34,64 & 1,74 & 25,94 & 6,96 & - \\
Borborema Potiguar & 34,16 & 16,15 & 13,23 & 4,78 & - \\
Serra Verde & 20,18 & 1,47 & 12,40 & 6,31 & - \\
Litoral de São Bento do Norte & 16,78 & 1,69 & 5,18 & 9,91 & - \\
Açu e Apodi & 15,52 & $-3,58$ & 18,55 & 0,55 & - \\
Salineira Norte-riograndense & 15,00 & 11,70 & 1,49 & 1,81 & - \\
Seridó & 10,21 & 1,99 & 8,18 & 0,04 & - \\
Natal & 5,55 & 5,01 & 1,13 & $-0,59$ & - \\
Agreste Potiguar & $-1,95$ & $-2,30$ & 0,97 & $-0,62$ & - \\
\hline ESTADO & 10,87 & 6,15 & 7,06 & 1,23 & $-3,57$ \\
\hline
\end{tabular}

Fonte: Dados básicos do Anuário Estatístico do Rio Grande do Norte - FIDEC. 
Tabela 15 - Decomposição da taxa média regional e estadual, em efeitos explicativos do crescimento da produção das principais culturas, Rio Grande do Norte, 198589.

\begin{tabular}{l|c|c|c|c|c}
\hline \multirow{2}{*}{ Microrregiões/Estado } & \multicolumn{5}{|c}{$1985-89$} \\
\cline { 2 - 6 } & $\begin{array}{c}\text { Taxa anual de } \\
\text { crescimento da } \\
\text { produção (\%) }\end{array}$ & $\begin{array}{c}\text { Efeito } \\
\text { Área }\end{array}$ & $\begin{array}{c}\text { Efeito } \\
\text { Rendimento }\end{array}$ & $\begin{array}{c}\text { Efeito } \\
\text { Composição }\end{array}$ & $\begin{array}{c}\text { Efeito } \\
\text { Localização }\end{array}$ \\
\hline Serra Verde & 12,58 & $-3,60$ & 3,93 & 12,25 & - \\
Litoral de São Bento do Norte & 10,68 & $-0,37$ & $-2,22$ & 13,27 & - \\
Salineira Norte-riograndense & 10,27 & $-6,79$ & 9,66 & 7,40 & - \\
Açu e Apodi & $-0,72$ & $-6,83$ & 1,15 & 4,96 & - \\
Natal & $-1,14$ & 2,14 & $-1,85$ & $-1,43$ & - \\
Sertão de Angicos & $-2,79$ & $-9,35$ & 2,57 & 3,99 & - \\
Agreste Potiguar & $-3,89$ & $-4,81$ & $-1,94$ & 2,86 & - \\
Borborema Potiguar & $-10,23$ & $-18,28$ & $-0,06$ & 8,11 & - \\
Seridó & $-10,50$ & $-13,90$ & $-0,87$ & 4,27 & - \\
Serrana Norte-riograndense & $-14,22$ & $-13,72$ & $-3,90$ & 3,40 & - \\
\hline ESTADO & $-2,49$ & $-9,13$ & $-0,31$ & 3,75 & 3,2 \\
\hline
\end{tabular}

Fonte: Dados básicos do Anuário Estatístico do Rio Grande do Norte - FIDEC.

Tabela 16 - Decomposição da taxa média regional e estadual, em efeitos explicativos do crescimento da produção das principais culturas, Rio Grande do Norte, 198992.

\begin{tabular}{l|c|c|c|c|c}
\hline \multirow{2}{*}{ Microrregiões/Estado } & \multicolumn{5}{|c}{$1989-92$} \\
\cline { 2 - 6 } & $\begin{array}{l}\text { Taxa anual de } \\
\text { rescimento da } \\
\text { produção (\%) }\end{array}$ & $\begin{array}{c}\text { Efeito } \\
\text { Área }\end{array}$ & $\begin{array}{c}\text { Efeito } \\
\text { Rendimento }\end{array}$ & $\begin{array}{c}\text { Efeito } \\
\text { Composição }\end{array}$ & $\begin{array}{c}\text { Efeito } \\
\text { Localização }\end{array}$ \\
\hline Litoral de São Bento do Norte & 2,89 & 8,07 & 2,19 & $-7,37$ & - \\
Salineira Norte-riograndense & 2,20 & 2,73 & $-8,86$ & 8,33 & - \\
Borborema Potiguar & 0,68 & $-6,32$ & 2,25 & 4,75 & - \\
Açu e Apodi & $-0,52$ & $-0,34$ & $-3,02$ & 2,84 & - \\
Agreste Potiguar & $-4,24$ & 0,70 & $-1,83$ & $-3,11$ & - \\
Serra Verde & $-5,38$ & $-3,34$ & $-3,79$ & 1,75 & - \\
Natal & $-6,29$ & 1,01 & $-4,53$ & $-2,77$ & - \\
Serrana Norte-riograndense & $-9,07$ & $-9,01$ & $-1,16$ & 1,10 & - \\
Seridó & $-11,75$ & $-16,35$ & $-0,85$ & 5,45 & - \\
Sertão de Angicos & $-17,24$ & $-26,57$ & 1,48 & 7,85 & - \\
\hline ESTADO & $-4,28$ & $-4,98$ & $-2,18$ & 0,19 & 2,69 \\
\hline
\end{tabular}

Fonte: Dados básicos do Anuário Estatístico do Rio Grande do Norte - FIDEC. 
de $2,14 \%$ ao ano e o efeito área foi de $1,74 \%$ ao ano. As culturas que mais expandiram área foram o caju, abacaxi, sorgo, milho, coco-da-baía e a mandioca. O sisal, algodão arbóreo e o algodão herbáceo foram as culturas que retrairam áreas. A região evoluiu em áreas plantadas das seguintes culturas: coco-da-baía de segunda passou para primeira em área cultivada; de quarta, para segunda com abacaxi; e para quarto lugar com o sorgo e o caju, as quais eram praticamente inexistentes em 1981. No início do período, o Litoral de São Bento do Norte detinha a maior percentagem de área com o sisal no Estado, passando a ocupar o terceiro lugar em 1992.

Os efeitos composição $(9,91 \%$ ao ano) e rendimento $(5,18 \%$ ao ano $)$ explicam $90 \%$ da variação na produção entre 1981 e 1985, no qual a taxa de crescimento da produção foi de $16,78 \%$ ao ano. Essas mudanças observadas na produtividade e no perfil produtivo da região podem ser associadas com a retração da área das culturas algodão arbóreo e herbáceo, e a expansão da área das culturas do abacaxi, mandioca, milho, banana, caju e coco-da-baía.

Entre 1985-89, o efeito composição (13,27\% ao ano) foi o principal responsável pela taxa anual crescimento da produção de $10,68 \%$, já que os efeitos área e rendimento foram negativos $(-0,37 \%$ e $-2,22 \%$ ao ano). Nesse subperíodo também se verifica a expansão da área plantada do abacaxi, caju, coco-da-baía, milho e sorgo, e retração do sisal e do algodão arbóreo e herbáceo.

No subperíodo seguinte (1989-92), essa região ficou em primeiro lugar em crescimento da produção $(2,89 \%$ ao ano). Verifica-se que o efeito composição foi negativo $(-7,37 \%$ ao ano), sendo compensada pela expansão de área $(E A=8,07 \%$ ao ano), principalmente do caju e do coco-da-baía, e pelo aumento da produtividade $(E R=2,19 \%$ ao ano). Essa microrregião também foi beneficiada pelos projetos de irrigação, incentivando principalmente a fruticultura tropical. Além da importância da fruticultura, essa região se destaca pelas suas pontencialidades pesqueiras, tanto em água salgada como água doce. Esta última é uma fonte de grande importância para alimentação da população. 


\section{Serra Verde}

No periodo de 1981 a 1992, Serra Verde apresentou a segunda maior taxa de crescimento anual da produção entre as microrregiões estudadas, ficando em torno de $9,95 \%$ ao ano (Tabela 13), explicada principalmente pelo efeito composição de 7,24\% ao ano e pelo efeito rendimento de $3,75 \%$ ao ano. Entre as culturas que mais expandiram área estão o caju, cana-de-açúcar, milho, coco-da-baía, abacaxi e o sorgo; e as que mais retraíram foram o algodão arbóreo, algodão herbáceo e o sisal. Em 1992, era a principal região em área plantada de sisal; segunda, em sorgo e cana-de-açúcar; e terceira, em abacaxi e coco-da-baía.

Entre 1981 e 1985, os efeitos rendimento e composição explicaram cerca de $93 \%$ da taxa de crescimento da produção ( $20,17 \%$ ao ano). No subperíodo seguinte (1985-89), o crescimento da produção continuou alto (12,58\% ao ano), tendo o efeito composição (12,25\% ao ano) como principal efeito explicativo, seguido do efeito rendimento de 3,93\% ao ano. No subperíodo de 1989-1992, verificou-se um declínio na produção de $-5,38 \%$ ao ano, explicado pela queda na produtividade ( $E R=-3,79 \%$ ao ano), como também pela diminuição da área plantada na microrregião ( $\mathrm{EA}=-3,34 \%$ ao ano). Além da agricultura, a caprinocultura e a pecuária de corte são importantes para região de Serra Verde.

\section{Salineira Norte-riograndense}

A região do Salineira Norte-riograndense foi a que obteve a terceira maior taxa média anual de crescimento da produção $(9,66 \%)$ no período de 1981-1992 (Tabela 13). Essa alta taxa de crescimento da produção é explicada pelas mudanças na composição da produção $(\mathrm{ECP}=6,21 \%$ ao ano), pelo aumento da produtividade ( $E R=2,50 \%$ ao ano) e pela expansão de área $(E A=0,95 \%$ ao ano). As culturas que expandiram áreas foram a mandioca, melão, milho, feijão, manga, caju e arroz. E a batata-doce, algodão herbáceo, algodão arbóreo, sorgo, banana e coco-da-baía foram as que retraíram área. Essa região se manteve como a mais importante em termos de área com relação às culturas do melão, sorgo e caju. 
Entre 1981 e 1985, o principal indicador de crescimento da produção foi o efeito área ( $11,70 \%$ ao ano), explicando $78 \%$ da taxa de crescimento da produção de $15 \%$ ao ano, podendo estar associado ao crescimento da área plantada de milho, feijão e sorgo. Os efeitos composição e rendimento foram respectivamente de $1,81 \%$ e $1,49 \%$ ao ano.

No subperiodo $1985-89$, o efeito área passa a ser negativo $(-6,79 \%$ ao ano), provavelmente devido à irregularidade das chuvas, como também ao declínio da área plantada do algodão arbóreo e herbáceo. Os efeitos explicativos que mais contribuíram para o crescimento da produção $(10,27 \%$ ao ano) foram o efeito rendimento com $9,66 \%$ ao ano, seguido do efeito composição com $7,4 \%$ ao ano, sendo que a razoável produtividade das culturas do caju, arroz e melão, pode ter influenciado nesses resultados. No subperiodo seguinte (1989-92), verifica-se uma desaceleração no seu crescimento, com uma taxa média anual de $2,2 \%$. O efeito composição da produção $(8,33 \%$ ao ano) e o efeito área $(2,73 \%$ ao ano) compensaram o efeito rendimento negativo $(-8,86 \%$ ao ano $)$.

Essa mudança na composição do produto e a expansão da área ocorrida nesse último subperíodo pode estar associada a vários fatores, tais como: o plano estadual de irrigação, retomado a partir de 1987, através da implantação dos perímetros irrigados, principalmente com as culturas do melão e da manga; o programa soerguimento da cultura do algodão no Estado, pelo qual a área do algodão herbáceo passou a se expandir, e os incentivos do governo estadual para as culturas do coco-dabaía e do caju.

$\mathrm{Na}$ região Salineira Norte-riograndense localiza-se o maior parque salineiro do Brasil, mais especificamente nos municípios de Macau, Mossoró e Areia Branca. Também se concentra nos municípios de Mossoró, Areia Branca e Alto do Rodrigues a produção petrolifera estadual, tanto de terra como marítima, sendo que o Rio Grande do Norte está entre os maiores produtores de petróleo terrestre do Brasil, além da produção de gás. 


\section{Borborema Potiguar}

No período de 1981-92, a região da Borborema Potiguar apresentou a quarta maior taxa de crescimento da produção entre as microrregiões estudadas, ficando em torno de 7,19\% ao ano (Tabela 13). Os efeitos explicativos área, rendimento e composição foram respectivamente, de $-2,37 \%, 3,08 \%$ e $6,48 \%$ ao ano. As culturas que expandiram suas áreas foram o sorgo, milho, feijão, mandioca, coco-da-baía, banana, caju e batata-doce, enquanto o algodão arbóreo, algodão herbáceo e o sisal retraíram áreas. Praticamente não existiam áreas cultivadas de batata-doce, caju e sorgo em 1981 . Em 1992, era a principal região em área plantada de feijão, a segunda em sisal, e a terceira em mandioca e milho.

O primeiro subperiodo (1981-85) foi o que apresentou maior crescimento da produção, com uma taxa média de $34,16 \%$ ao ano, sendo $86 \%$ dessa taxa explicada pelos efeitos área $(16,15 \%$ ao ano) e rendimento $(13,23 \%$ ao ano). No subperíodo seguinte (1985-89), a produção dessa região decresceu a uma taxa média anual de $-10,23 \%$, explicada pela diminuição da área plantada (EA=-18,28\% ao ano) e, em menor grau, pela queda de produtividade ( $E R=-0,06 \%$ ao ano). $O$ efeito composição foi de $8,11 \%$ ao ano. Entre 1989 e 1992, a produção da região voltou a crescer com uma taxa de $0,68 \%$ ao ano, explicada pelos efeitos composição $(4,75 \%$ ao ano) e rendimento $(2,25 \%$ ao ano). Entre as culturas que se destacaram em expansão de área estão o caju, milho, coco-da-baía e o abacaxi e em retração de área estão o algodão arbóreo, algodão herbáceo e o sisal.

\section{Sertão Angicos}

Comportamento semelhante a Borborema Potiguar teve a região de Sertão Angicos, com uma taxa anual de crescimento da produção entre 1981 e 1992 de 6,86\%, explicada principalmente pelo efeito composição de $6,25 \%$ ao ano e efeito rendimento de $4,02 \%$ ao ano. O efeito área foi de $-3,41 \%$ ao ano. O caju, milho, melão, sorgo e feijão foram as culturas que expandiram área na região. E em retração destacam-se o algodão arbóreo, manga, batata-doce e algodão herbáceo. Essa microrregião recebeu incentivos estaduais e da SUDENE para o reflorestamento com a cultura do caju. 
O subperíodo de 1981-85 foi o único que apresentou taxa de crescimento positivo da produção, tendo o efeito rendimento $(26,39 \%$ ao ano) como principal componente explicativo, seguido da expansão de área $(E A=16,15 \%$ ao ano). Nos subperiodos subseqüentes (1985-89 e 1989-92), as taxas de crescimento da produção foram declinantes $(-2,79 \%$ e $-17,25 \%$ ao ano, respectivamente) explicadas pela retração da área que anulou os efeitos positivos do rendimento e da composição da produção.

\section{Açu-Apodi}

$\mathrm{Na}$ microrregião de Açu-Apodi, as variações da produção parecem estar relacionadas às mudanças na composição do produto e no rendimento, as quais tiveram maior peso relativo entre 1981-85 e 1985-89. No terceiro subperíodo (1989-92), o efeito composição da produção continuou positivo $(2,84 \%$ ao ano), diminuindo um pouco os efeitos das taxas de crescimento negativo da área $(E A=-0,34 \%$ ao ano) e do rendimento ( $E R=-3,02 \%$ ao ano).

Verifica-se que o subperíodo 1981-85 foi responsável pelo aumento da produção na microrregião Açu-Apodi, entre 1981 e 1992, uma vez que essa região sofreu queda na produção nos subperíodos subseqüentes, explicada em grande parte pela retração de área.

As principais culturas que sofreram retração de área no periodo analisado (1981-92) foram principalmente o algodão arbóreo, cana-de-açúcar, batata-doce, algodão herbáceo e sorgo. E as culturas que mais expandiram áreas foram o melão, manga, caju e milho. Em 1992, tornou-se a mais importante região de algodão herbáceo, e a segunda mais importante de melão, banana, caju e manga em área plantada.

Como as microrregiões do Litoral de São Bento do Norte e a Salineira Norte-riograndense, essa região também foi beneficiada com a implantação de áreas irrigadas com fruticultura, que em geral apresentam alta produtividade. É também em Açu-Apodi que se encontram as reservas de calcário, empregado na agricultura para a correção dos solos e na fabricação de cimento. 


\section{Serrana Norte-riograndense}

A microrregião Serrana Norte-riograndense apresentou crescimento da produção apenas no subperiodo 1981-85, com uma taxa de $34,64 \%$ ao ano, tendo os efeitos rendimento, composição e área contribuído com $25,94 \%, 6,96 \%$ e $1,74 \%$ ao ano, respectivamente. Esse subperiodo foi responsável pelo crescimento da produção no periodo de 1981 a 1992, já que os subperíodos subseqüentes (1985-89 e 1989-92) apresentaram taxas crescimentos negativas. As culturas que expandiram área foram o caju, milho, melão e a batata-doce. Com relação à percentagem de área plantada das culturas, destaca-se como a região: mais importante em arroz e milho; a segunda, em algodão arbóreo; e a terceira, em algodão herbáceo, feijão, melão e banana.

A diminuição da área plantada, muitas vezes acompanhada de queda da produtividade no último subperíodo analisado (1989-92), comportamento verificado em praticamente todas as microrregiões, provavelmente foi influenciado pelo período extremamente seco dos anos 90, com exceção das regiões Salineira Norte-riograndense e Litoral de São Bento do Norte, onde se encontra o maior número de área irrigada do Estado.

\section{Agreste Potiguar}

Entre 1981 e 1992, a microrregião do Agreste Potiguar foi a que sofreu a segunda maior retração na produção agrícola no Estado, com uma taxa de crescimento anual negativa de $-3,29 \%$, tendo sido essa taxa negativa em todos os subperiodos analisados.

No subperíodo de 1981-85, a região Agreste apresentou um declínio na produção de $-1,95 \%$ ao ano, sendo explicado pela diminuição da área plantada ( $E A=-2,3 \%$ ao ano) e por mudanças na estrutura produtiva $(\mathrm{ECP}=-0,62 \%$ ao ano). No subperiodo seguinte (1985-89), a queda na produção aumentou (-3,89\% ao ano), tendo como principais componentes explicativos os efeitos de área e rendimento de $-4,81 \%$ e $-1,94 \%$ ao ano, respectivamente. Com exceção do caju, manga, arroz e abacaxi, as culturas restantes apresentaram queda de produtividade. O efeito composição, mesmo 
apresentando um sinal positivo $(2,86 \%$ ao ano), foi insuficiente para compensar a queda da área e da produtividade.

A tendência de declínio continua no Agreste entre 1989 a 1992, tendo os componentes rendimento $(-1,83 \%$ ao ano) e composição da produção $(-3,11 \%$ ao ano como principais efeitos explicativos do decréscimo da produção de $-4,24 \%$ ao ano. A queda de produção das culturas pode estar sendo compensada com a presença crescente da pecuária de corte e de leite.

Entre 1981 e 1992, as culturas que mais expandiram área no Agreste foram o caju, sorgo, abacaxi, milho e a cana-de-açúcar; e as que mais retraíram foram o algodão herbáceo, algodão arbóreo e, em menores proporções, a banana, a manga e a mandioca. Com relação à percentagem de área plantada das culturas, destaca-se como a região mais importante de abacaxi e mandioca; a segunda, de milho e feijão; e a terceira de batata-doce.

\section{Seridó}

A região do Seridó apresentou a maior retração da produção no Estado, no período analisado $(-3,84 \%$ a.a. $)$. O único subperíodo de crescimento da produção na microrregião foi entre 1981-85, no qual a produção cresceu a uma taxa de 10,21\% ao ano, tendo como componentes explicativos o efeito rendimento com $8,18 \%$ ao ano, o efeito área de $1,99 \%$ ao ano e o efeito composição da produção de $0,04 \%$ ao ano. Nos dois subperiodos seguintes (1985-89 e 1989-92), o crescimento da produção foi negativo, $-10,5 \%$ e $-11,75 \%$ ao ano, respectivamente, nos quais a principal fonte de variação foi a redução de área.

No período analisado (1981-92), em termos de área plantada, o Seridó se manteve como a mais importante região produtora de algodão arbóreo; segunda em arroz e batata-doce; e quarta em mandioca, milho e manga. As culturas que expandiram áreas foram o caju, manga e milho. Entre as que se retraíram estão o algodão arbóreo, sorgo, algodão herbáceo e batata-doce. Com a queda da produção dessas culturas, provavelmente a maior parte da área foi substituída pela pastagem para pecuária mista. 
Essa região é rica em produtos minerais, destacando-se principalmente o mármore e a scheelita, sendo que esta última foi responsável por $95 \%$ da produção nacional, utilizada em produtos bélicos e elétricos.

\section{Natal}

A microrregião de Natal manteve-se estável entre 1981 e 1992, com uma taxa de crescimento anual da produção de $-0,22 \%$, provavelmente por ser a região industrial do Estado. O único subperiodo de crescimento da produção na região foi entre 1981-85, no qual a produção cresceu a uma taxa de 5,55\% ao ano. Os efeitos explicativos área, rendimento e composição foram respectivamente, de 5,01\%,1,13\% e $-0,59 \%$ ao ano. Nos dois subperiodos seguintes (1985-89 e 1989-92), o crescimento da produção foi negativo, $-1,14 \%$ e $-6,29 \%$ ao ano, respectivamente. Com exceção do primeiro subperiodo (1981-85), os efeitos rendimento e composição foram os principais responsáveis pela queda na produção.

Entre as culturas que expandiram áreas destacam-se o caju e, com uma menor taxa de crescimento de área, estão o milho, coco-da-baía, feijão e cana-de-açúcar. O algodão herbáceo e a mandioca foram as culturas que apresentaram retração de área. Essa região se manteve como a mais importante, em termos de área, em cana-de-açúcar, banana e manga. Em 1992, passou a ocupar o primeiro lugar em área plantada de batatadoce, o segundo em mandioca e coco-da-baía e terceiro em caju. A região de Natal também se destaca na pecuária de leite, não incluída neste estudo.

\subsection{Análise no Estado para o conjunto das culturas}

De 1981 a 1992, a taxa anual de crescimento da produção estadual foi de 1,66\% ao ano (Tabela 13), sendo o subperiodo de 1981-85 o responsável por esse aumento, uma vez que o Estado apresentou queda na produção nos subperíodos subseqüentes (1985-89 e 1989-92). Além de uma certa regularidade climática, outra explicação plausível para esse comportamento no primeiro subperíodo é que o Rio Grande do Norte pode ter sentido os efeitos das políticas de incentivo à modernização, 
como a expansão da pesquisa e dos serviços de extensão estadual, o crédito rural subsidiado que nos inícios dos anos 80 teve um comportamento razoável, favorecendo o crescimento do uso de insumos modernos, como fertilizantes, defensivos, sementes melhoradas e irrigação.

Como foi visto anteriormente, nesse período algumas regiões apresentaram elevadas taxas de crescimento da produção, destacando-se as microrregiões do Litoral de São Bento do Norte, Salineira Norte-riograndense e Serra Verde, enquanto as regiões do Seridó, Agreste Potiguar e Natal apresentaram quedas de produção. Por outro lado, as culturas como: milho, melão, caju, abacaxi, feijão, sorgo, arroz e coco-dabaía tiveram nesse período aumentos significativos na produção, enquanto as culturas do algodão arbóreo, algodão herbáceo e o sisal apresentaram quedas significativas. Ao contrário dos resultados obtidos em outras regiões do País, nos quais culturas de subsistência foram substituídas pelas de exportação ou industrializáveis, no Rio Grande do Norte percebe-se que entre as culturas que mais cresceram estão três de subsistência, ou seja, milho, feijão e arroz, assim como melão, caju, coco-da-baía e abacaxi que podem ser consideradas culturas de exportação e/ou industrializáveis.

Das fontes de crescimento, o efeito composição foi o de maior peso explicativo, com 92\% de participação no crescimento da produção, indicando a mudança de culturas de menor valor por unidade de área para aquelas de maior valor. $\mathrm{O}$ efeito localização geográfica ( $1,33 \%$ ao ano) e o efeito rendimento $(1,17 \%$ ao ano) respondem por $151 \%$ do crescimento acima, ao contrário do efeito área que contribui sozinho para a retração $-143 \%$ da variação ocorrida. Como pode ser observado na Tabela 13, praticamente todas as microrregiões tiveram retração de área.

Esta importância dos efeitos composição da produção e rendimento contrastam com os resultados obtidos por Patrick (1975), que ao analisar as fontes de crescimento da produção do Rio Grande do Norte entre 1948 e 1969, verificou que a expansão de área foi o principal componente explicativo do aumento da produção. Esses resultados obtidos em décadas diferentes vêm confirmar as influências das políticas nacionais sobre o Estado, pois antes dos anos 70 o crescimento da agricultura brasileira se deu principalmente pela incorporação de novas áreas e, pós 70 , difundiu-se a política 
agrícola voltada para o aumento da produtividade da terra e do trabalho, através da modernização do setor.

O primeiro subperiodo (1981-85) foi de crescimento da produção, com uma taxa anual de $10,87 \%$. Essa taxa foi influenciada pelo aumento da produtividade ( $E R=7,06 \%$ ao ano) seguido da expansão de área ( $E A=6,15 \%$ ao ano) e da mudanças na composição da produção $(\mathrm{ECP}=1,23 \%$ ao ano). Esses efeitos respondem por $133 \%$ da variação do crescimento, enquanto o efeito localização, de $-3,57 \%$ ao ano, respondeu pela retração de $33 \%$ da variação ocorrida. Como pode ser visto na Tabela 14 , praticamente todas as regiões tiveram expansão de área e ganhos na produtividade. Já a mudança na composição da produção, que participou com $11 \%$ da variação do crescimento, foi mais importante nas microrregiões do Litoral de São Bento do Norte, Serra Verde, Serrana Norte-riograndense e Borborema Potiguar.

$\mathrm{Na}$ análise do segundo subperíodo (1985-89), observa-se que a taxa de crescimento da produção começou a declinar $(-2,49 \%$ ao ano), tendo como principal fator explicativo a retração da área $(\mathrm{EA}=-9,13 \%$ ao ano), seguida pela queda na produtividade ( $E R=-0,31 \%$ ao ano), em menor proporção. Com exceção da microrregião de Natal, todas as outras regiões tiveram diminuição da área plantada entre 1985 e 1989. O efeito composição de $3,75 \%$ ao ano e o efeito localização geográfica, que passou a ser positivo ( $E L G=3,2 \%$ ao ano), contrabalançaram os resultados negativos dos outros dois efeitos.

De 1989 a 1992, os efeitos tiveram um comportamento similar ao do segundo subperíodo. A taxa de crescimento da produção continuou declinante, com uma magnitude maior de $-4,28 \%$ ao ano, principalmente devido à diminuição da área plantada ( $E A=-4,98 \%$ ao ano) e queda na produtividade ( $E R=-2,18 \%$ ao ano). Os efeitos composição e localização geográfica continuaram positivos, mas com uma participação relativa menor em relação ao período anterior. 


\section{CONCLUSÃO}

Os resultados do estudo mostram que as mudanças ocorridas na produção norte-riograndense na década de oitenta não seguiram um padrão convencional em termos de grupos de culturas. Das culturas que apresentaram taxa de crescimento positiva, três foram de culturas tradicionais de subsistência: milho $(24,14 \%)$, feijão $(12,1 \%)$ e arroz $(7,46 \%)$; três foram de culturas não tradicionais no Estado: melão $(16,6 \%)$, abacaxi $(13,03 \%)$ e sorgo $(11,56 \%)$; duas foram de culturas tradicionais e em geral plantadas por grandes e médios produtores: caju $(14,74 \%)$ e coco-da-baía $(5,99 \%)$; finalmente uma das mais tradicionais culturas do Estado: cana-de-açúcar, com uma taxa anual de crescimento de $1,23 \%$. Os principais efeitos explicativos do comportamento dessas culturas se alternaram principalmente entre o efeito rendimento e o efeito área. $\mathrm{O}$ efeito localização geográfica foi positivo praticamente para todas as culturas.

Dentre as culturas que apresentaram declínio na produção, três são industriais e/ou de exportação: algodão arbóreo $(-22,18 \%)$, sisal $(-11,93 \%)$ e o algodão herbáceo $(-6,29 \%)$; duas culturas de subsistència: batata-doce $(-7,17 \%)$ e mandioca $(-2,91 \%)$; e por último, a banana $(-1,87 \%)$ uma cultura recente no Estado e de alto valor comercial. A retração da área foi a principal fonte explicativa dessas taxas de crescimento negativas da produção.

Esses resultados foram confirmados na subdivisão do efeito área em efeitos substituição e escala. Percebe-se que as culturas que apresentaram taxas positivas de crescimento na produção estão entre aquelas que mais expandiram sua área. As culturas que mais incorporaram áreas, em ordem decrescente, foram o caju, milho, coco-da-baía, feijão, cana-de-açúcar, melão, abacaxi e a manga. As que se retraíram em área, como o algodão arbóreo, algodão herbáceo, sisal, mandioca, batata-doce e banana, foram as que apresentaram declínio na produção. $O$ arroz foi a única cultura cuja produção cresceu, apesar da retração na área plantada. 
Esses resultados de incorporação de área, entretanto, devem ser considerados com uma certa reserva, já que o presente estudo não levou em consideração todas as culturas plantadas no Estado e também não foram incluídas as áreas com pastagens. Isso pode ter introduzido algumas distorções nos resultados das culturas que incorporaram áreas, devido ao modelo não permitir inferências sobre áreas que não estejam dentro do sistema de produção analisado.

As microrregiões que apresentaram taxas médias anuais positivas de crescimento da produção entre 1981 e 1992 foram Litoral de São Bento do Norte $(10,64 \%)$, Serra Verde $(9,95 \%)$, Salineira Norte-riograndense $(9,66 \%)$, Borborema Potiguar (7,19\%), Sertão de Angicos (6,86\%), Açu-Apodi (4,95\%) e a Serrana Norteriograndense $(2,69 \%)$. Os principais indicadores de crescimento da produção nessas microrregiões foram as mudanças na composição da produção e o aumento do rendimento, seguidas da expansão de área, casos típicos das regiões Salineira Norteriograndense e do Litoral de São Bento do Norte. Em todas as microrregiões percebe-se uma variação relativa dos efeitos explicativos conforme os subperiodos analisados.

Constatou-se uma certa dificuldade em agrupar as microrregiões por culturas, pois todas expandiram áreas tanto de culturas de subsistência, como industriais e de exportação. Ou seja, entre as culturas que se expandiram estão o caju, milho, melão, sorgo, coco-da-baía, abacaxi e feijão. E as principais culturas que retraíram sua área foram o algodão arbóreo, algodão herbáceo e, em algumas regiões, o sisal. As regiões do Seridó $(-3,84 \%$ a.a.) e do Agreste Potiguar $(-3,29 \%$ a.a.) foram as de maior decréscimo na produção agrícola no Estado, devido à retração na área plantada. A microrregião de Natal apresentou um comportamento estável no periodo.

Percebe-se que o subperíodo de maior crescimento foi entre 1981 e 1985 , tanto na análise estadual, como por microrregiões e por cultura, provavelmente influenciado pela regularidade climática do triènio 1984-85-86 e pela facilidade de obtenção do crédito subsidiado no início da década de 80.

O setor das culturas selecionadas do Rio Grande do Norte cresceu a uma taxa de 1,66\% ao ano, entre 1981 e 1992. Os efeitos composição da produção, rendimento e localização geográfica foram de maior importância em termos de explicação 
da variação na taxa de crescimento da produção agrícola estadual, ao contrário do efeito área que contribuiu negativamente.

Portanto, o crescimento da produção agrícola no Rio Grande do Norte não ocorreu via incorporação de novas áreas. Ao contrário, houve sensivel contração nas áreas cultivadas com as principais culturas. Isso sugere que cerca de 228 mil hectares foram destinados a outros usos que não aqueles considerados no estudo (pastagens, reflorestamento, etc.).

Dentre os fatores explicativos das taxas de crescimento da produção, o que mais se destacou foi o efeito composição da produção apontando mudanças no sistema de produção. Em todos os subperíodos, esse efeito apresentou-se positivo e com tendência crescente. Tais resultados sugerem que os incentivos para surgimento das culturas irrigadas, a recuperação de culturas como o caju e o coco-da-baía, a melhoria no material genético das culturas de subsistência e a evolução dos preços das culturas podem ter contribuído positivamente para a mudança da composição da produção estadual.

O segundo efeito de maior importância explicativa foi o rendimento. Como dito anteriormente, no período analisado foram importantes as políticas de crédito rural subsidiado que incentivaram o uso dos chamados "insumos modernos", assim como a expansão e melhoria dos serviços de pesquisa e extensão estadual, que podem ter influenciado a produtividade das culturas analisadas. Supondo que os 228 mil hectares foram utilizados com pastagens e reflorestamento, tudo leva a crer que o fator terra é escasso, indicando que as inovações tecnológicas poupadoras de terras constituem elemento-chave para aumentar a produtividade da terra, confirmando a teoria de Hayami $\&$ Ruttan (1975).

$O$ terceiro fator que contribuiu de forma significativa foi $\mathrm{o}$ efeito localização geográfica, indicando a existência de vantagens locacionais concorrendo para o crescimento da produção como um todo. Isso sugere que os recursos produtivos estariam sendo alocados de maneira mais eficiente e que a cada deslocamento das culturas, principalmente a partir do segundo subperiodo (1985-89), poderão ocorrer vantagens comparativas no médio prazo. 
O efeito área foi o que menos contribuiu para o crescimento da produção agrícola do Rio Grande do Norte. Com exceção do primeiro subperiodo (1981-85), o efeito área apresentou-se sempre negativo, revelando ser uma importante fonte de declínio da produção em todos os niveis da análise. Ocorreu uma forte retração de área de culturas de importância econômica relevante para o Estado, como foi o caso do algodão arbóreo, algodão herbáceo e sisal, principalmente explicada pelas políticas comercial e de preços e pela incidência de pragas. Mas, como se sabe, a questão climática também exerce uma influência forte sobre o desempenho da produção agricola norte-riograndense, seja pela elevada concentração das precipitações em curto espaço de tempo (seca verde), seja pelo baixo nível de pluviosidade, fazendo com que a agricultura de sequeiro continue sendo uma atividade de alto risco para o produtor rural.

Apesar do Rio Grande do Norte ter $90 \%$ da sua área no polígono da seca, o que se traduz em condições adversas para o desenvolvimento da agricultura, percebe-se que, na década de 80, o Estado passou por fortes modificações na composição da produção, com crescente expansão da área cultivada com fruticultura, e com relativa retração das áreas de produtos que eram tradicionais no Estado (caso das culturas do algodoeiro e do sisal). Embora a área cultivada com frutas (especialmente irrigada) ainda seja bastante inferior à área de outras culturas tradicionais como o feijão e o milho, o valor por hectare da produção frutícola é substancialmente mais alto. É possível, assim, que a expansão da fruticultura, inclusive abrangendo novas regiões do Estado no futuro, possa vir a se tornar um fator desacelerador da migração rural-urbana. Para tal, entretanto, será necessário que a política pública de incentivo à expansão da irrigação desenvolva programas específicos para pequenos produtores preferencialmente em parceria com a pesquisa e extensão rural do Estado.

Além da política de irrigação, é necessário que o governo também continue com os programas de incentivos à produção e distribuição de sementes melhoradas pelos setores de pesquisa e extensão do Estado, como também com o programa de recuperação e expansão das áreas do caju e do coco-da-baía, atividades que muito contribuem para aumentos de produtividade e de renda das unidades produtivas. 


\section{REFERÊNCIAS BIBLIOGRÁFICAS}

AGUIAR, G.M. de. Agriculturas no nordeste: apreciações e sugestões políticas. Petrópolis: Vozes, 1985. 208p.

ALMEIDA, M. B. de; SOARES, F.A. Nordeste versus Brasil: desempenho econômicosocial. Revista Econômica do Nordeste. v.25, n. 4, p. 475-498, 1994

ALVES, E. Pobreza rural no Brasil: desafios da extensão e da pesquisa. 4. ed. Brasilia:Ministério da Irrigação;CODEVASF, 1988. 79p.

ALVES, E.; CONTINI, E. A modernização da agricultura brasileira. In: BRANDÃO, A.S.P. (Ed.) Os principais problemas da agricultura brasileira: análise e sugestões. Brasília: PMOE/IPEA, 1992. cap. 2, p. 49-97.

ANUÁRIO ESTATÍSTICO DO BRASIL. Rio de Janeiro, 1994.

BARROS, G.S.A.C.; ARAÚJO, P.F.C. A política de crédito rural no Brasil: perspectivas para os anos 90. Piracicaba:FEALQ;CEPEA, 1991b. 17 p. (Relatório de Resultados, 11).

BARROS, G.S.A.C.; ARAÚJO, P.F.C. Oferta e demanda de crédito rural no Brasil: algumas evidências empiricas sobre seus determinantes. Piracicaba: FEALQ;CEPEA, 1991a. 32 p. (Relatório de Resultados, 9). 
BARROS, J.R.M; ÁLVARO, M. Insumos agricolas: evolução recente e perspectivas. In: BRANDÃO, A.S. P. (Ed.) Os principais problemas da agricultura brasileira: análise e sugestões. Brasilia: PMOE/IPEA, 1992. cap. 8, p. 295-332.

BRASIL. Superintendência do Desenvolvimento do Nordeste. Levantamento exploratório: reconhecimento dos solos do Estado do Rio Grande do Norte. Recife, $1971.531 \mathrm{p}$.

BOLSA DE MERCADORIAS \& FUTUROS. Séries históricas do Algodão: janeiro de 1980 a março de 1996. BM\&F: São Paulo, 21p. 1996.

CAMARGO, A.M.M.P. de. Substituição regional entre as principais atividades agrícolas no Estado de São Paulo. Piracicaba, 1983. 236p. Dissertação (Mestrado) - Escola Superior de Agricultura "Luiz de Queiroz", Universidade de São Paulo.

CAMARGO, A.M.M.P. de; ANEFALOS, L.C.; CASER, D.V.; COELHO, P.J.; OLIVETTI, M.P.A. Alteração na composição da agropecuária no Estado de São Paulo, 1983-1993. Informações Econômicas, v.25, n. 5, p. 49-81, 1995.

CARDOSO, C.E.L. Efeitos de políticas públicas sobre a produção de mandioca no Brasil. Piracicaba, 1996. 176p. Dissertação (Mestrado) - Escola Superior de Agricultura "Luiz de Queiroz", Universidade de São Paulo.

CARNEIRO, R. Relações de produção e emprego na agricultura do Nordeste. Economia Política, v. 2/1, n. 5, p. 123-138, jan./mar. 1982.

CORREAA, A.M.C.; HOFFMANN, R. Distribuição da renda entre pessoas ocupadas na agricultura brasileira, 1981-90. In: CONGRESSO BRASILEIRO DE ECONOMIA E SOCIOLOGIA RURAL, 33., Curitiba, 1995. Anais. Brasilia:SOBER, 1995. p.1461-1478 
CORTEZ, I.B.; RÊGO, M.F.F.; CABRAL, M.J.O; SOBRAL, M.L.N.; JÚNIOR, O.M. Perfil do Estado do Rio Grande do Norte 1993. Natal:Secretaria de Planejamento e Finanças;FIDEC, 1994. 210p

FASSARELA, R.A. Padrões de crescimento no setor de culturas do Estado do Espírito Santo. Piracicaba, 1987. 42p. Dissertação (Mestrado) - Escola Superior de Agricultura “Luiz de Queiroz", Universidade de São Paulo.

Fundação Instituto de Desenvolvimento do Rio Grande do Norte. Anuário estatístico do Rio Grande do Norte. Natal, 1981/1994.

Fundação Instituto de Desenvolvimento do Rio Grande do Norte. Recursos naturais renováveis: água e solos. Natal, 1983. 112p.

Fundação Instituto de Desenvolvimento do Rio Grande do Norte. Perfil do Estado do Rio Grande do Norte 1993. Natal, 1994. 210p.

Fundação Instituto Brasileiro de Geografia e Estatística. Sinopse preliminar do censo demográfico. VII Recenseamento geral 1970. Brasil. Rio de Janeiro, 1971.

Fundação Instituto Brasileiro de Geografia e Estatística. Censo demográfico de 1980. Rio de Janeiro, 1982.

Fundação Instituto Brasileiro de Geografia e Estatística. Censo demográfico de 1990. Rio de Janeiro, 1992.

FURTADO, C. Análise do "modelo brasileiro". In: A estrutura agrária no subdesenvolvimento brasileiro. Rio de Janeiro:Civilização Brasileira, 1973. p.91122. 
GASQUES, J.G.; VERDE, C.M.V.; Crescimento da agricultura brasileira e política agrícola nos anos oitenta. Agricultura em São Paulo. v.37, n. I, p. 183-204, 1990.

GOMES, G.M. Diretrizes para um plano de ação do BNB (1991-95) - Uma estratégia para acelerar o desenvolvimento do Nordeste Revista Econômica do Nordeste. v.24, n. 1/4, p. 9-149, 1993.

HAYAMI, Y;; RUTTAN, V. "Preços dos fatores e mudança técnica no desenvolvimento da agricultura: Estados Unidos e Japão 1880-1960". In: ARAÚJO, P.F.C.; SCHUH, G. Desenvolvimento da agricultura: educação, pesquisa e assistência técnica. São Paulo:Pioneira, 1975 . v. 2, p. 53-75.

HOFFMANN, R. Distribuição da renda na agricultura. In: BRANDÃO, A.S.P. (Ed.) Os principais problemas da agricultura brasileira: análise e sugestões. Brasilia: PMOE/IPEA, 1992. cap. 1, p. 11-48.

HOFFMANN, R.; KAGEYAMA, A. Modernização da agricultura e distribuição de renda no Brasil. Pesquisa e Planejamento Econômico, v. 15, n. 1, p.171-208, abr. 1985.

HOFFMANN, R.; CARVALHO, A.V.; KAGEYAMA, A.A.A.; WIENDT, M.L.T.B.; QUEDA, $O$. Inovações tecnológicas e transformações recentes na agricultura brasileira. Piracicaba: ESALQ;FEALQ;FINEP, 1985. 4v. (Relatório de Pesquisa).

IGREJA, A.C.M. Evolução da pecuária bovina de corte no Estado de São Paulo no período 1969-84. Piracicaba, SP. 1987. 197p. Dissertação (Mestrado) - Escola Superior de Agricultura "Luiz de Queiroz", Universidade de São Paulo. 
IGREJA, A.C.M.; CARMO, M.S.; GALVÃO, C.A.; PELLEGRINI, R.M.P. Análise quantitativa do desempenho da agricultura paulista, 1966-77. Agricultura em São Paulo, t. I/II, p.117-157, 1983.

JOHNSTON, B.F.; MELLOR, J.W. The role of agriculture in economic development. American Economic Review, v. 51, p. 566-93, Sept. 1961.

KAGEYAMA, A.; SILVA, J.G. Os resultados da modernização agricola dos anos 70 . Estudos Econômicos, v. 13, n. 3, p. 537-559, set./dez. 1983.

LANDIM, J.R.M.; MONTEIRO, M.A.A. O processo de modernização da agricultura e a estrutura produtiva da microrregião homogênea Serra de Jaboticabal, SP. Revista de Economia e Sociologia Rural, v. 29, n. 3, p. 229-248, jul./set. 1991.

LEITE, P.S. Desenvolvimento rural: um novo enfoque. Revista Econômica do Nordeste, v.14, n.3, p. 469-508, 1983.

MOREIRA, J.A.N.; BELTRÃO, N.E.M.; FREIRE, E.C.; FILHO, M. B.N.; SANTOS, R.F. dos; NETO. M.S.A. Decadência do algodoeiro mocó e medidas para o seu soerguimento no Nordeste brasileiro. Campina Grande:EMBRAPA/CNPA, 1995. $12 \mathrm{p}$.

NAKANO, Y. O crédito rural num contexto de modernização da economia brasileira. In: SEMINÁRIO NACIONAL "AS DIFÍCEIS OPÇÕES DO FINANCIAMENTO RURAL", Belo Horizonte, 1992. Anais. Belo Horizonte:FAEMG, 1992, p. 1-18.

OLIVETTI, M.P.A.; CAMARGO, A.M.M.P. de Evolução da composição agrícola no Brasil e principais regiões produtoras, 1968-89. Agricultura em São Paulo, v.39, n.1, p.155-177, 1992. 
PAIVA, R.M. Modernização e dualismo tecnológico na agricultura. Pesquisa e Planejamento, v. 1, n. 2, p. 171-234, dez. 1971.

PATRICK, G.F. Fontes de crescimento da agricultura brasileira: o setor de culturas. In: CONTADOR, C.R. Tecnologia e desenvolvimento agrícola. Rio de Janeiro, IPEA;INPES, 1975. p.89-110. (Série Monográfica, 17).

PEREIRA, L.C.B. Economia brasileira: uma introdução crítica. 2.ed. São Paulo: Brasiliense, 1982. 169p.

PEREIRA, R.C. Modernização da agricultura das regiões Nordeste e Sudeste do Brasil; pós "milagre" econômico. Piracicaba, 1993. 148 p. Dissertação (Mestrado) - Escola Superior de Agricultura "Luiz de Queiroz", Universidade de São Paulo.

ROMÃO, M.C.; BEZERRA, J.F.; VERGOLINO, J.R.; IRMÃO, J.F.; GOMES, G.M. Produção, emprego e distribuição de renda no Rio Grande do Norte. Recife: UFPE, 1990. 326p.

SCHUH, G .E. Modernização da agricultura brasileira. In: ARAÚJO, P. F. C.; SCHUH, G. E. Desenvolvimento da agricultura. São Paulo:Pioneira, 1975. p. 281-311.

SILVA, J.G. A modernização dolorosa. Rio de Janeiro: Zahar, 1982. 192p.

SILVA, J.G.; KAGEYAMA, A.; BUAINAIN, A.M; REYDON, B.P.; SILVEIRA, J.M.J.; PINTO, L.C.G.; MELLO, M.T.L.; BIRAL, M.A.M.; PORTO, M.Y.; LEMOS, P.B.; RAMOS, P.; FONSECA, R.B.; MORAES, S.H.N.; BELIK, W. Estrutura agrária e irrigação no Nordeste. Revista Econômica do Nordeste. v. 20, n. 4 , p. 431-452, 1989. 
VERAS, B. et al. Desequilibrio econômico inter-regional brasileiro. In: CONGRESSO NACIONAL. O desenvolvimento desigual da economia no espaço brasileiro. Brasilia, 1993. v.1, p. 1-89. (Relatório Final).

YOKOYAMA, L.P. O crescimento da produção e modernização das lavouras em Goiás no período de 1975-1984. Piracicaba, SP. 1988. 109p. Dissertação (Mestrado) Escola Superior de Agricultura "Luiz de Queiroz", Universidade de São Paulo.

ZOCKUN, M.H.G.P. A expansão da soja no Brasil: alguns aspectos da produção. São Paulo, 1978. 228p. Dissertação (Mestrado) - Faculdade de Economia e Administração, Universidade de São Paulo. 


\section{APÊNDICES}




\section{Apêndice 1}

Relação das microrregiões e os respectivos municípios do Estado Rio Grande do Norte

SALINEIRA NORTE-RIOGRANDENSE

Alto do Rodrigues

Areia Branca

Baraúna

Carnaubais

Grossos

Guamaré

Macau

Mossoró

Pendências

Serra do Mel

LITORAL DE SÃO BENTO DO NORTE

Galinhos

Pedra Grande

São Bento do Norte

Touros

AÇU E APODI

Açu

Apodi

Augusto Severo

Campo Grande

Felipe Guerra

Gov. Dix-Sept Rosado

Ipanguaçu

Itaú

Janduis

Paraú

São Rafael

Severiano Melo

Upanema

\section{SERTÃO DE ANGICOS}

Afonso Bezerra

Angicos

Pedro Avelino

Santana do Matos

\section{SERRA VERDE}

Bento Fernandes

Caiçara do Rio do Vento

Jandaíra

Jardim de Angicos

João Câmara

Lages

Parazinho

Pedra Preta

Poço Branco

Pureza

Taipu

\section{NATAL}

Arês

Baía Formosa

Canguaretama

Ceará Mirim

Parnamirim

Espírito Santo

Extremoz

Goianinha

Macaiba

Maxaranguape

Montanhas

Natal 
NATAL

Nísia Floresta

Pedro Velho

São Gonçalo do Amarante

São José de Mipibu

Sen. Georgino Avelino

Tibau do Sul

Vila Flor

SERRANA NORTE-RIOGRANDENSE

Água Nova

Alexandria

Almino Afonso

Antônio Martins

Coronel João Pessoa

Dr. Severiano

Encanto

Francisco Dantas

Frutuoso Gomes

João Dias

José da Penha

Lucrécia

Luís Gomes

Marcelino Vieira

Martins

Messias Targino

Olho d'Água Borges

Paraná

Patu

Pau dos Ferros

Pilões

Portalegre

Rafael Fernandes

Rafael Godeiro
SERRANA NORTE-RIOGRANDENSE

Riacho da Cruz

Riacho de Santana

Rodolfo Fernandes

São Francisco do Oeste

São Miguel

Taboleiro Grande

Tenente Ananias

Umarizal

Viçosa

\section{SERIDÓ}

Acarí

Caicó

Carnaúba dos Dantas

Cerro Corá

Cruzeta

Currais Novos

Equador

Florânia

Ipueira

Jardim de Piranhas

Jardim do Seridó

Jucurutu

Lagoa Nova

Ouro Branco

Parelhas

Santana do Seridó

São Fernando

São João do Sabugi

São José do Seridó

São Vicente

Serra Negra do Norte

Timbaúba dos Batistas 
BORBOREMA POTIGUAR

Barcelona

Campo Redondo

Coronel Ezequiel

Jaçanã

Japi

Lagoa de Velhos

Lajes Pintadas

Monte das Gameleiras

Rui Barbosa

Santa Cruz

São Bento do Trairi

São José de Campestre

São Tomé

Serra de São Bento

Sítio Novo

Tangará

\section{AGRESTE POTIGUAR}

Boa Saúde

Bom Jesus

Brejinho

lelmo Marinho

Lagoa d'Anta

Lagoa de Pedra

Lagoa Salgada

Montanhas

Monte Alegre

Nova Cruz

Passa e Fica

Passagem

Presidente Juscelino

Riachuelo

Santo Antônio

São Paulo do Potengi
AGRESTE POTIGUAR

São Pedro

Senador Elói de Souza

Serrinha

Várzea

Vera Cruz 
TABELA 2.1 - Caracterização da estrutura fisica das microrregiões homogêneas: Salineira Norte-riograndense, Açu e Apodi, Litoral de São Bento do Norte. Sertão de Angicos, Serra Verde c Natal, do Estado do Rio Grande do Norte

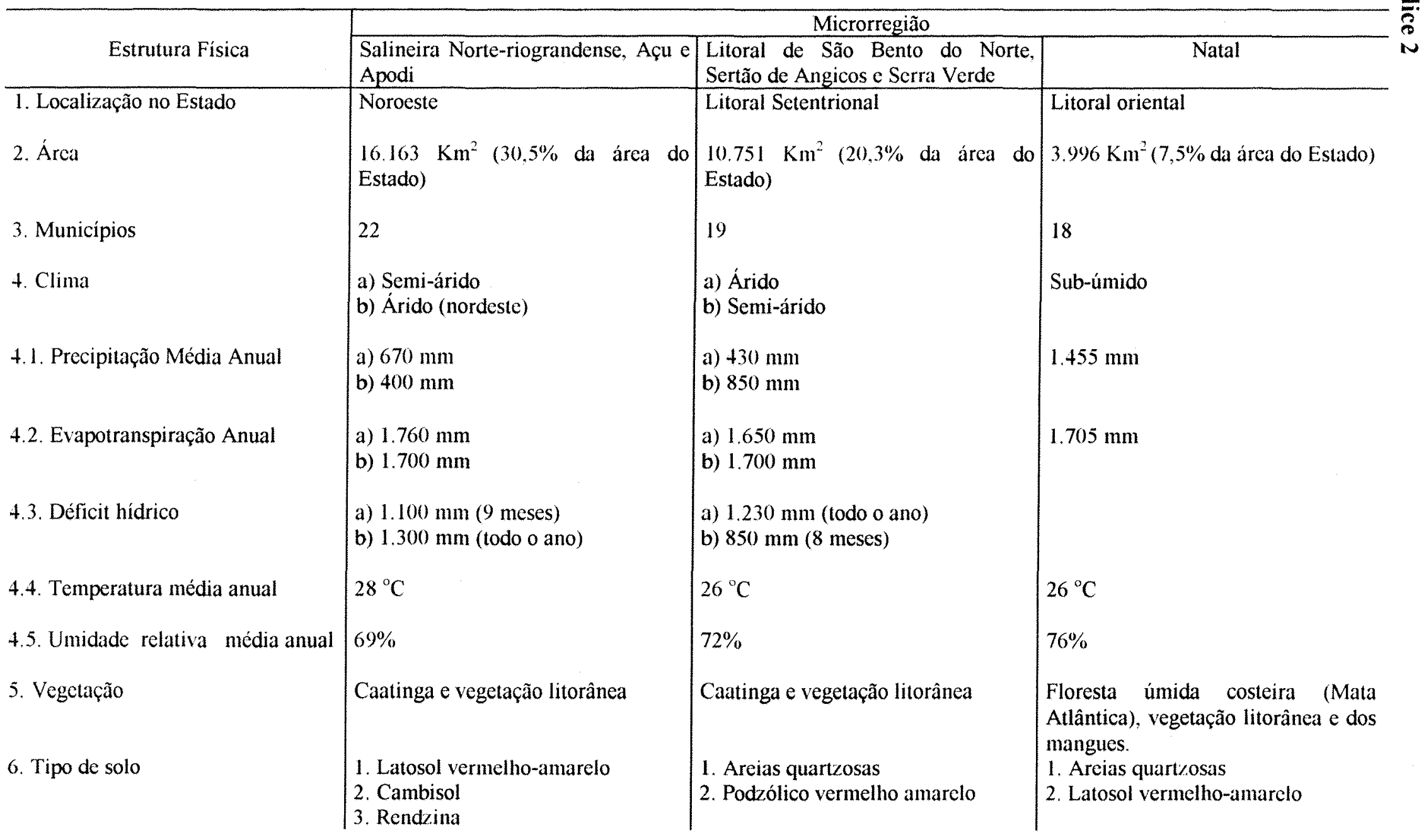


TABELA 2.1 - Caracterização da estrutura física das microrregiões homogêneas: Salineira Norte-riograndense, Açu e Apodi, Litoral de São Bento do Norte, Sertão de Angicos, Serra Verde e Natal, do Estado do Rio Grande do Norte

(continuação)

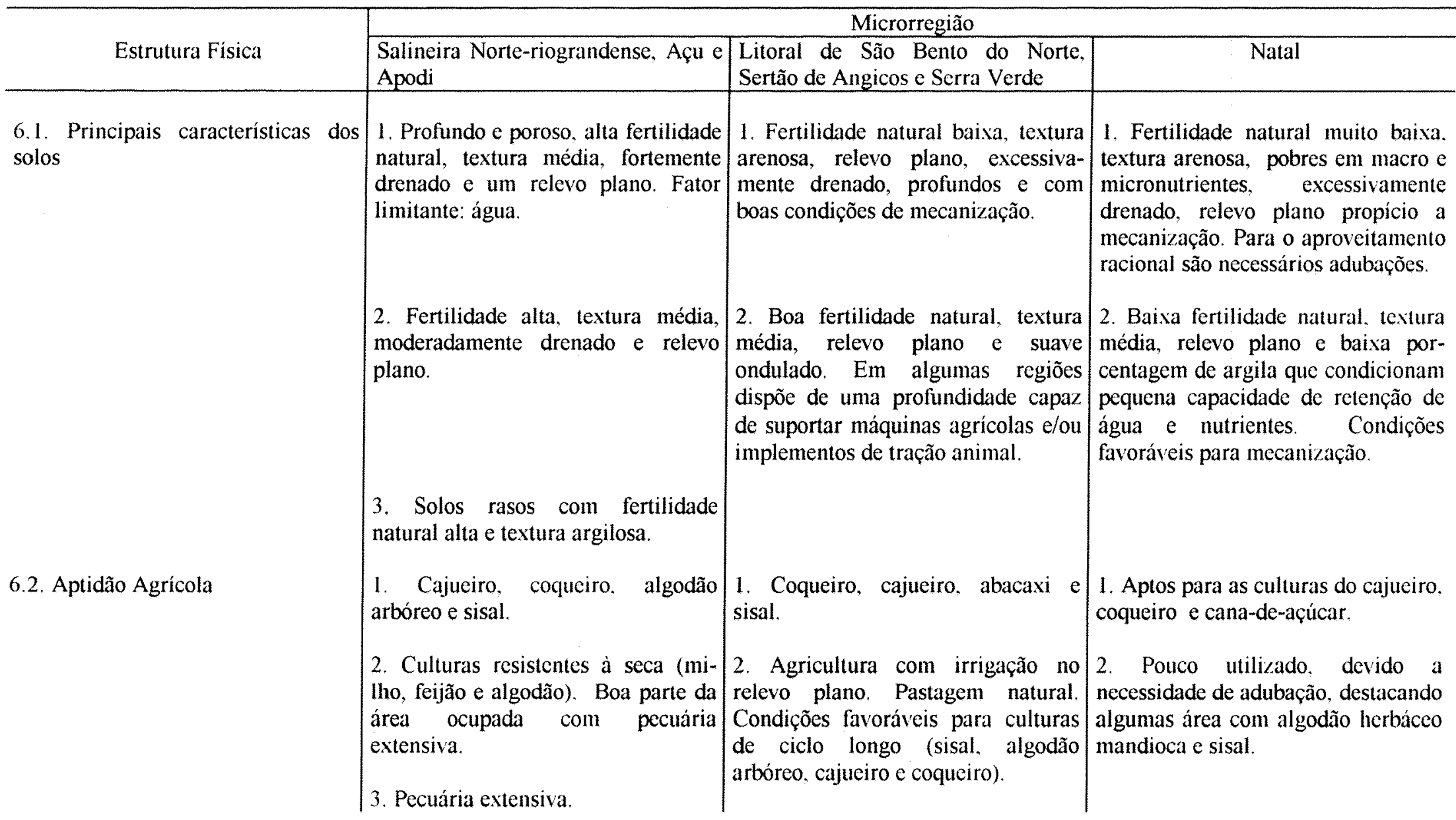


TABELA 2.1 - Caracterização da estrutura física das microrregiões homogêneas: Salineira Norte-riograndense, Açu e Apodi, Litoral de São Bento do Norte, Sertão de Angicos, Serra Verde e Natal, do Estado do Rio Grande do Norte

(continuação)

\begin{tabular}{|c|c|c|c|}
\hline \multirow[b]{2}{*}{ Estrutura Física } & \multicolumn{3}{|c|}{ Microrregião } \\
\hline & $\begin{array}{l}\text { Salineira Norte-riograndense, Açu e } \\
\text { Apodi }\end{array}$ & $\begin{array}{l}\text { Litoral de São Bento do Norte, } \\
\text { Sertão de Angicos e Serra Verde }\end{array}$ & Natal \\
\hline 7. Recurso Hidrico & & & \\
\hline 7.1. Água Subterrânea & $\begin{array}{l}\text { Aquíferos: Barreiros, Açu, Jandaíra } \\
\text { e Cristalino. São bastante utilizados } \\
\text { nos projetos hidroagricola, através } \\
\text { de perfuração de poços. }\end{array}$ & $\begin{array}{l}\text { Aqüiferos de Barreiros (norte) boa } \\
\text { qualidade, servindo para todos os } \\
\text { usos. Aqüiferos de Jandaira e Açu } \\
\text { (restrições para o consumo humano } \\
\text { e animal) }\end{array}$ & $\begin{array}{l}\text { Aqüíferos de Barreiros com } \\
\text { excelente qualidade, servindo tanto } \\
\text { para o consumo humano quanto para } \\
\text { o animal. }\end{array}$ \\
\hline 7.2. Água superficial & $\begin{array}{l}\text { Bacias do Piranhas-Açu (leste e do } \\
\text { Apodi-Mossoró (ocste). A maioria } \\
\text { dos rios tem regime intermitente. }\end{array}$ & $\begin{array}{l}\text { Bacia do Ceará Mirim (sul) e no } \\
\text { sudoeste pelos afluentes da margem } \\
\text { direita do rio Açu. Região marcada } \\
\text { pela intermitências dos rios. }\end{array}$ & $\begin{array}{l}\text { Bacias hidrográficas: Ceará Mirim, } \\
\text { Potengi, Jacú e Curimataú. Toda a } \\
\text { rede hidrográfica apresenta-se } \\
\text { intermitente. }\end{array}$ \\
\hline 7.3. Área de várzea (ha) & 21.780 & 2.215 & 25.751 \\
\hline
\end{tabular}

T'Aqüíferos são reservatórios subterrâneos naturais de água, com características próprias, tanto de quantidade como de qualidade.

FONTE: Dados originais das seguintes publicações: Recursos naturais renováveis: água e solos (IDEC, 1983); Perfil do Estado do Rio Grande do Norte (IDEC, 1993); Aptidão agrícola das terras do Estado do Rio Grande do Norte (Ministério da Agricultura, 1978); Levantamento exploratório Reconhecimento de solos do Estado do Rio Grande do Norte (Ministério da Agricultura, 1971): Recursos naturais renováveis: água e solos (IDEC, 1983) e do Perfil do Estado do Rio Grande do Norte (IDEC, 1993).

Tabela elaborada pela autora. 
TABELA 2.2 - Caracterização da estrutura física das microrregiões homogêneas: Serrana Norte-riograndense, Seridó, Borborema e Agreste Potiguar, do Estado do Rio Grande do Norte

\begin{tabular}{|c|c|c|c|}
\hline \multirow[b]{2}{*}{ Estrutura Física } & \multicolumn{3}{|c|}{ Microrregião } \\
\hline & Serrana Norte-riograndense & Seridó & Borborema e Agreste Potiguar \\
\hline 1. Localização no Estado & Sudoeste & Centro-sul & Agreste \\
\hline 2. Área & $5.120 \mathrm{Km}^{2}(9,7 \%$ da área do Estado $)$ & $\begin{array}{l}9.372 \mathrm{Km}^{2}(17,7 \% \text { da área do } \\
\text { Estado })\end{array}$ & $\begin{array}{l}7.613 \mathrm{Km}^{2} \quad(14,3 \% \text { da área do } \\
\text { Estado })\end{array}$ \\
\hline 3. Municípios & 33 & 22 & 37 \\
\hline 4. Clima & $\begin{array}{l}\text { a) Semi-árido (parte central) } \\
\text { b) Sub-úmido seco (leste/oeste) }\end{array}$ & $\begin{array}{l}\text { a) Árido (oriental) } \\
\text { b) Semi-árido (centro-sul e leste) } \\
\text { c) Sub-úmido seco (oeste) }\end{array}$ & Semi-árido \\
\hline 4.1. Precipitação Média Anual & $\begin{array}{l}\text { a) } 700 \mathrm{~mm} \\
\text { b) } 1.000 \mathrm{~mm}\end{array}$ & $\begin{array}{l}\text { a) } 430 \mathrm{~mm} \\
\text { b) } 700 \mathrm{~mm} \\
\text { c) } 1000 \mathrm{~mm}\end{array}$ & $570 \mathrm{~mm}$ \\
\hline 4.2. Evapotranspiração Anual & $\begin{array}{l}\text { a) } 1.736 \mathrm{~mm} \\
\text { b) } 1.744 \mathrm{~mm}\end{array}$ & $\begin{array}{l}\text { a) } 1.650 \mathrm{~mm} \\
\text { b) } 1.700 \mathrm{~mm} \\
\text { c) } 1.700 \mathrm{~mm}\end{array}$ & $1.000 \mathrm{~mm}$ \\
\hline 4.3. Déficil hidrico & $\begin{array}{l}\text { a) } 990 \mathrm{~mm} \text { (nove meses) } \\
\text { b) } 960 \mathrm{~mm} \text { (sete meses) }\end{array}$ & $\begin{array}{l}\text { a) } 1.230 \mathrm{~mm} \text { (todo o ano) } \\
\text { b) } 1.000 \mathrm{~mm} \text { (nove meses) } \\
\text { c) } 1.700 \mathrm{~mm}\end{array}$ & $1.000 \mathrm{~mm}$ (todo o ano) \\
\hline 4.4. Temperatura média anual & $28^{\circ} \mathrm{C}$ & $27^{\circ} \mathrm{C}$ & $26^{\circ} \mathrm{C}$ \\
\hline 4.5. Umidade relativa média anual & $67 \%$ & 59 a $65 \%$ & $72 \%$ \\
\hline 5. Vegetação & Caatinga & Caatinga & Caatinga e floresta seca \\
\hline 6. Tipo de solo & Podzólico vermelho amarelo & $\begin{array}{l}\text { 1. Solos litólicos } \\
\text { 2. Bruno não cálcico } \\
\text { 3. Latosol vermelho amarelo }\end{array}$ & $\begin{array}{l}\text { 1. Planosol solódico } \\
\text { 2. Solos litólicos }\end{array}$ \\
\hline
\end{tabular}


TABELA 2.2 - Caracterização da estrutura fisica das microrregiões homogêneas: Serrana Norte-riograndense, Seridó, Borborema e Agreste Potiguar, do Estado do Rio Grande do Norte.

(continuação)

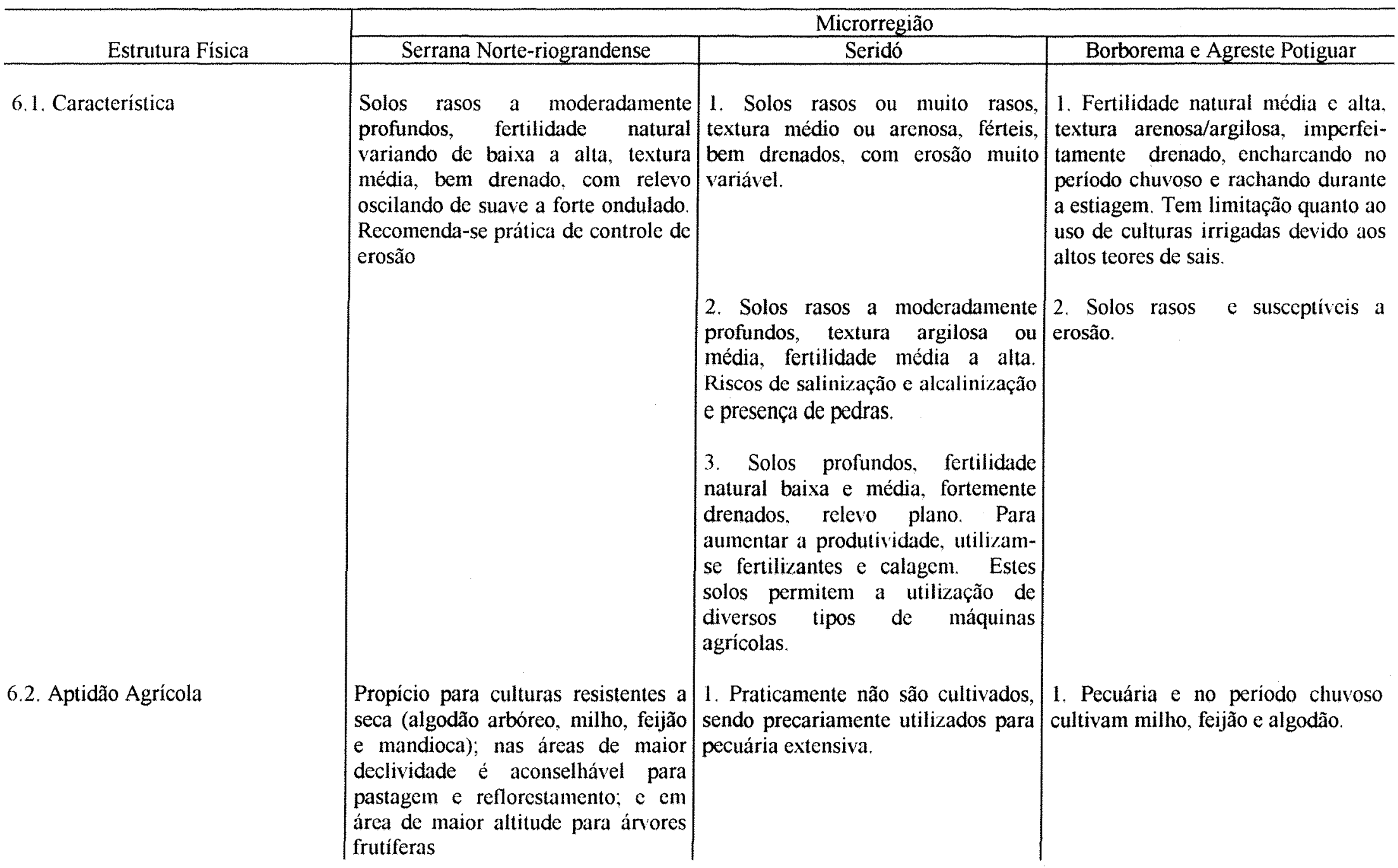


TABELA 2.2 - Caracterização da estrutura física das microrregiões homogêneas: Serrana Norte-riograndense, Seridó, Borborema e Agreste Potiguar, do Estado do Rio Grande do Norte.

(continuação)

\begin{tabular}{|c|c|c|c|}
\hline \multirow[b]{2}{*}{ Estrutura Física } & \multicolumn{3}{|c|}{ Microrregião } \\
\hline & Serrana Norte-riograndense & Seridó & Borborema e Agreste Potiguar \\
\hline 6.2. Aptidão Agrícola & & $\begin{array}{l}\text { 2. Pecuária extensiva e o cultivo de } \\
\text { palma forrageira. Na época chuvosa } \\
\text { é utilizado com as culturas de } \\
\text { subsistência de ciclo curto. } \\
\text { 3. Sisal, fruticultura c agricultura de } \\
\text { subsistência. }\end{array}$ & $\begin{array}{l}\text { 2. Devem ser preservados ou } \\
\text { destinados a agricultura extensiva. }\end{array}$ \\
\hline 7.1. Água Subterrânea & $\begin{array}{l}\text { Aquífero Cristalino e o Aluvião (boa } \\
\text { qualidade para o consumo humano e } \\
\text { animal) }\end{array}$ & & $\begin{array}{l}\text { Aqüífero Aluvião (boa qualidade } \\
\text { para o uso humano e animal) }\end{array}$ \\
\hline 7.2. Água superficial & $\begin{array}{l}\text { Bacia do Apodi e o alto curso da } \\
\text { bacia Apodi-Mossoró, no sentido } \\
\text { sul-norte, apresentando regime } \\
\text { intermitente. }\end{array}$ & $\begin{array}{l}\text { Sub-bacia do Seridó (oriental); Bacia } \\
\text { Piranhas-Açu (central) e ao norte a } \\
\text { Bacia do Potengi. Praticamente } \\
\text { todos os rios tem regime } \\
\text { intermitente. }\end{array}$ & $\begin{array}{l}\text { Bacia do Ceará Mirim (norte); Bacia } \\
\text { do Potengi (central); Bacia do Trairi } \\
\text { (leste) e as Bacias de Jacú e } \\
\text { Curimataú (sudoeste). todas com } \\
\text { regime intermitente. }\end{array}$ \\
\hline 7.3. Área de várzea (ha) & 6.113 & 65.728 & 11.680 \\
\hline
\end{tabular}

FONTE: Dados originais das seguintes publicações: Recursos naturais renováveis: água e solos (IDEC, 1983); Perfil do Estado do Rio Grande do Norte (IDEC, 1993); Aptidão agrícola das terras do Estado do Rio Grande do Norte (Ministério da Agricultura, 1978); Levantamento exploratório Reconhecimento de solos do Estado do Rio Grande do Norte (Ministério da Agricultura. 1971); Recursos naturais renováveis: água e solos (IDEC, 1983) e do Perfil do Estado do Rio Grande do Norte (IDEC, 1993).

Tabela elaborada pela autora. 


\section{Apêndice 3}

Tabela 3.1 - Participação percentual das principais culturas na área colhida total no Estado do Rio Grande do Norte, 1980/1993

\begin{tabular}{|c|c|c|c|c|c|c|c|c|c|c|c|c|c|c|}
\hline \multirow[b]{2}{*}{ Cultura } & \multicolumn{13}{|c|}{ Participação percentual } & \multirow[b]{2}{*}{1993} \\
\hline & 1980 & 1981 & 1982 & 1983 & 1984 & 1985 & 1986 & 1987 & 1988 & 1989 & 1990 & 1991 & 1992 & \\
\hline$\overline{\text { Abacaxi }}$ & 0,05 & 0,06 & 0,05 & 0,08 & 0,05 & 0,05 & 0,06 & 0,18 & 0,40 & 0,27 & 0,28 & 0,28 & 0,21 & 0,46 \\
\hline Alg. Arbóreo & 30,96 & 37,04 & 34,34 & 33,36 & 25,55 & 30,10 & 25,93 & 12,39 & 13,77 & 13,16 & 16,95 & 1,61 & 1,43 & 0,72 \\
\hline Alg. herbáceo & 19,34 & 14,48 & 17,66 & 10,25 & 15,27 & 15,01 & 7,17 & 1,04 & 6,31 & 5,50 & 1,48 & 2,95 & 5,11 & 0,21 \\
\hline Arroz & 0,64 & 0,45 & 0,52 & 0,84 & 0,66 & 0,72 & 0,89 & 0,64 & 0,70 & 0,68 & 0,49 & 0,75 & 0,46 & 0,04 \\
\hline Banana & 0,41 & 0,40 & 0,37 & 0,58 & 0,29 & 0,20 & 0,29 & 0,56 & 0,49 & 0,43 & 0,67 & 0,52 & 0,45 & 0,76 \\
\hline Batata doce & 0,92 & 0,95 & 0,81 & 0,88 & 0,63 & 0,64 & 0,59 & 0,96 & 0,71 & 0,68 & 0,86 & 0,60 & 0,52 & 0,97 \\
\hline Caju & 5,65 & 6,22 & 5,99 & 9,09 & 4,99 & 5,17 & 5,79 & 10,09 & 8,88 & 11,99 & 25,30 & 19,25 & 19,01 & 40,60 \\
\hline Cana-de-açúcar & 4,40 & 5,36 & 5,90 & 8,72 & 4,73 & 4,96 & 6,02 & 10,15 & 8,21 & 7,43 & 12,35 & 9,37 & 8,06 & 15,72 \\
\hline Coco-da-baía & 1,78 & 2,07 & 1,85 & 2,99 & 1,67 & 1,89 & 2,14 & 3,79 & 3,65 & 3,49 & 5,83 & 5,23 & 5,17 & 10,81 \\
\hline Feijão & 15,75 & 15,44 & 14,94 & 12,80 & 21,42 & 17,51 & 21,53 & 28,73 & 24,67 & 25,49 & 13,56 & 28,60 & 28,62 & 6,88 \\
\hline Mandioca & 6,60 & 7,81 & 6,74 & 8,27 & 4,77 & 5,01 & 6,10 & 9,70 & 8,33 & 6,77 & 9,41 & 7,30 & 7,48 & 13,52 \\
\hline Manga & 0,22 & 0,24 & 0,21 & 0,29 & 0,16 & 0,16 & 0,17 & 0,29 & 0,21 & 0,21 & 0,43 & 0,30 & 0,31 & 0,65 \\
\hline Melão & 0,04 & 0,07 & 0,07 & 0,12 & 0,06 & 0,04 & 0,05 & 0,08 & 0,09 & 0,14 & 0,35 & 0,36 & 0,34 & 1,01 \\
\hline Milho & 7,51 & 3,42 & 4,65 & 4,71 & 14,98 & 13,40 & 17,34 & 13,11 & 19,49 & 20,36 & 8,85 & 19,75 & 20,65 & 5,58 \\
\hline Sisal & 4,21 & 4,57 & 4,07 & 5,57 & 3,10 & 3,39 & 3,62 & 5,89 & 0,96 & 1,14 & 1,90 & 0,91 & 0,53 & 0,94 \\
\hline Sorgo & 0,21 & 0,13 & 0,87 & 0,60 & 0,90 & 1,00 & 1,44 & 0,92 & 2,20 & 1,15 & 0,19 & 1,43 & 0,94 & 0,04 \\
\hline Total & 98,67 & 98,71 & 99,04 & 99,16 & 99,22 & 99,24 & 99,13 & 98,53 & 99,07 & 98,88 & 98,90 & 99,20 & 99,31 & 98,88 \\
\hline
\end{tabular}

Fonte: Anuário Estatístico do Rio Grande do Norte de 1981 a 1993. 
Tabela 3.2 - Participação percentual das 16 culturas no valor da produção total das culturas no Estado do Rio Grande do Norte, $1980 / 1993$

\begin{tabular}{|c|c|c|c|c|c|c|c|c|c|c|c|c|c|c|}
\hline \multirow[b]{2}{*}{ Cultura } & \multicolumn{14}{|c|}{ Participação percentual } \\
\hline & 1980 & 1981 & 1982 & 1983 & 1984 & 1985 & 1986 & 1987 & 1988 & 1989 & 1990 & 1991 & 1992 & 1993 \\
\hline Abacaxi & 0,50 & 0,72 & 0,55 & 0,54 & 0,54 & 0,51 & 1,24 & 3,63 & 3,76 & 2,74 & 4,58 & 2,77 & 5,16 & 6,49 \\
\hline Alg. Arbóreo & 9,92 & 12,04 & 10,68 & 3,53 & 12,60 & 12,62 & 4,45 & 1,49 & 3,33 & 2,08 & 1,34 & 0,61 & 0,19 & 0,03 \\
\hline Alg. herbáceo & 8,37 & 6,09 & 7,82 & 4,02 & 17,00 & 6,25 & 2,22 & 0,90 & 3,76 & 1,31 & 1,90 & 2,76 & 1,99 & 0,02 \\
\hline Arroz & 0,19 & 0,42 & 0,37 & 0,33 & 1,07 & 1,41 & 1,76 & 0,27 & 0,98 & 1,16 & 0,60 & 0,99 & 0,39 & 0,11 \\
\hline Banana & 3,05 & 3,10 & 2,88 & 3,65 & 2,57 & 1,67 & 3,16 & 2,77 & 1,80 & 2,96 & 4,23 & 2,80 & 4,84 & 4,32 \\
\hline Batata doce & 3,90 & 3,68 & 2,55 & 4,01 & 1,76 & 1,90 & 2,04 & 3,16 & 1,25 & 1,40 & 2,33 & 1,10 & 1,34 & 1,72 \\
\hline Caju & 7,05 & 3,43 & 3,24 & 2,98 & 2,70 & 2,63 & 5,91 & 4,79 & 6,85 & 3,14 & 8,39 & 10,02 & 7,32 & 2,67 \\
\hline Cana-de-açúcar & 24,34 & 19,89 & 39,57 & 44,64 & 19,34 & 25,66 & 18,60 & 28,38 & 16,22 & 53,05 & 23,37 & 18,77 & 18,60 & 15,62 \\
\hline Coco-da-baía & 4,98 & 5,30 & 4,64 & 3,81 & 6,80 & 8,12 & 5,72 & 5,64 & 7,70 & 2,68 & 3,79 & 5,50 & 9,93 & 13,85 \\
\hline Feijão & 6,18 & 5,97 & 5,20 & 5,64 & 11,50 & 11,88 & 20,77 & 4,48 & 11,29 & 8,58 & 5,12 & 12,56 & 14,13 & 1,39 \\
\hline Mandioca & 23,55 & 30,96 & 14,02 & 19,12 & 13,81 & 13,92 & 15,27 & 35,64 & 31,84 & 11,34 & 30,46 & 27,32 & 18,35 & 32,03 \\
\hline Manga & 1,20 & 1,15 & 1,54 & 0,99 & 0,68 & 1,08 & 1,89 & 1,12 & 0,72 & 1,33 & 2,11 & 1,46 & 2,20 & 2,42 \\
\hline Melão & 1,96 & 1,68 & 1,87 & 1,99 & 0,68 & 0,67 & 0,74 & 0,91 & 0,62 & 2,60 & 5,51 & 3,74 & 5,30 & 13,38 \\
\hline Milho & 0,39 & 0,33 & 0,67 & 0,43 & 4,95 & 4,90 & 8,06 & 0,71 & 6,51 & 2,78 & 1,30 & 4,84 & 5,07 & 0,61 \\
\hline Sisal & 2,24 & 2,86 & 1,84 & 2,00 & 1,41 & 2,69 & 1,88 & 1,76 & 0,26 & 0,36 & 0,86 & 0,55 & 0,30 & 0,26 \\
\hline Sorgo & 0,01 & 0,09 & 0,42 & 0,07 & 0,76 & 0,75 & 1,68 & 0,08 & 1,23 & 0,46 & 0,04 & 1,01 & 0,56 & 0,03 \\
\hline Total & 97,81 & 97,72 & 97,86 & 97,75 & 98,17 & 96,67 & 95,40 & 95,72 & 98,12 & 97,97 & 95,93 & 96,77 & 95,67 & 94,94 \\
\hline
\end{tabular}

